\title{
Bathymetry and Vegetation in Isolated Marsh and Cypress Wetlands in the Northern Tampa Bay Area, 2000-2004
}

By Kim H. Haag, Terrie M. Lee, and Donald C. Herndon

Prepared in cooperation with

Pinellas County, Southwest Florida Water Management District, and Tampa Bay Water

Scientific Investigations Report 2005-5109 


\section{U.S. Department of the Interior Gale A. Norton, Secretary}

\section{U.S. Geological Survey \\ P. Patrick Leahy, Acting Director}

\section{U.S. Geological Survey, Reston, Virginia: 2005}

For sale by U.S. Geological Survey, Information Services

Box 25286, Denver Federal Center

Denver, CO 80225

For more information about the USGS and its products:

Telephone: 1-888-ASK-USGS

World Wide Web: http://www.usgs.gov/

Any use of trade, product, or firm names in this publication is for descriptive purposes only and does not imply endorsement by the U.S. Government.

Suggested Citation: Haag, K.H., Lee, T.M., and Herndon, D.C., 2005, Bathymetry and Vegetation in Isolated Marsh and Cypress Wetlands in the Northern Tampa Bay Area, 2000-2004: U.S. Geological Survey Scientific Investigations Report 2005-5109, $49 p$. 


\section{Contents}

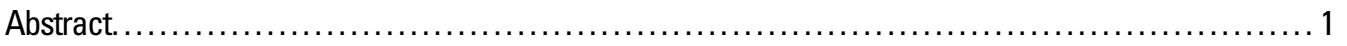

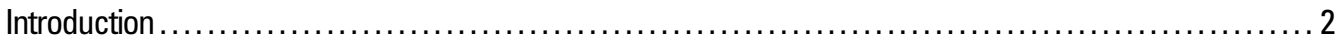

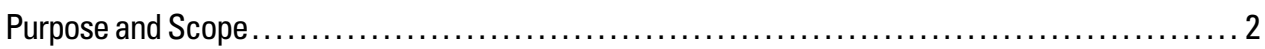

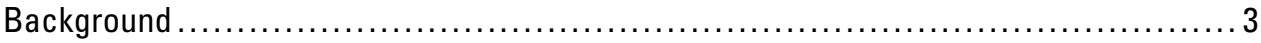

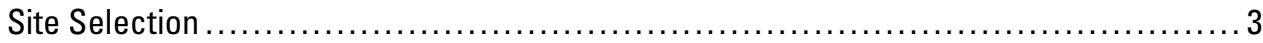

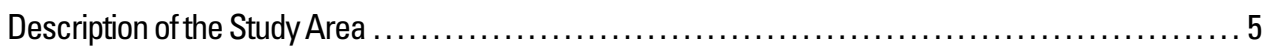

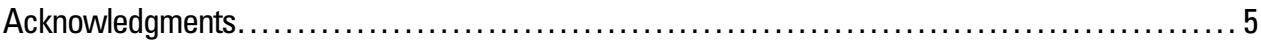

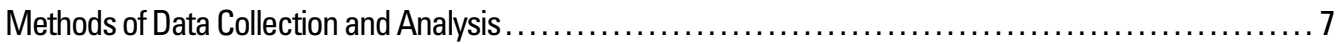

Delineation of the Wetland Perimeter and Determination of Perimeter Elevations................ 7

Measurement of Wetland Stage and Collection of Bathymetric Data $\ldots \ldots \ldots \ldots \ldots \ldots \ldots \ldots \ldots \ldots \ldots \ldots \ldots \ldots \ldots \ldots$

Creation of Bathymetric Contour Maps and Calculation of Wetland Area and Stored Water Volume . . . . . 10

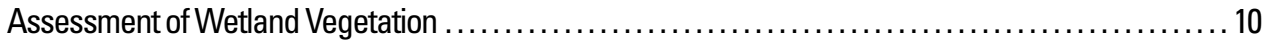

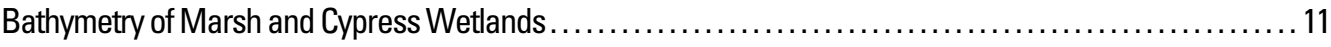

Stage-Area-Volume Relations for Marsh and Cypress Wetlands................................. 11

Potential Effects of Bathymetric Mapping Approach on Stage-Area and Stage-Volume Relations. . . . . . . . 17

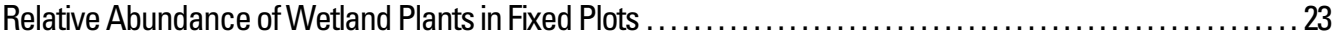

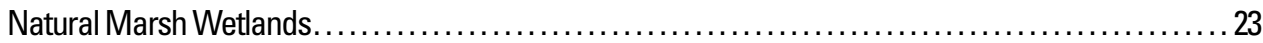

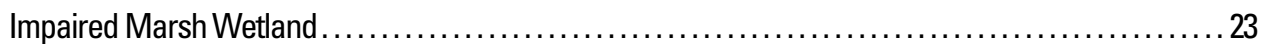

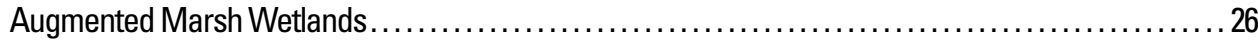

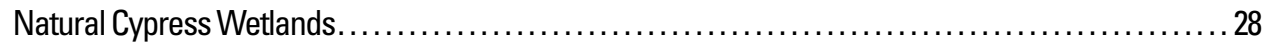

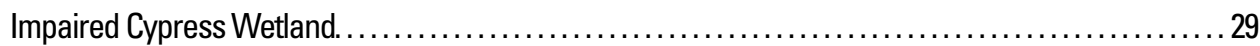

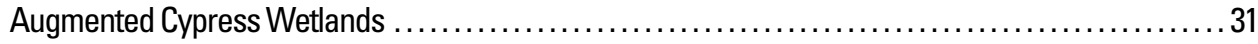

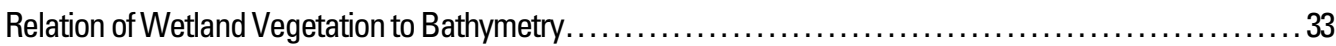

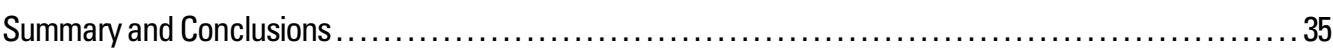

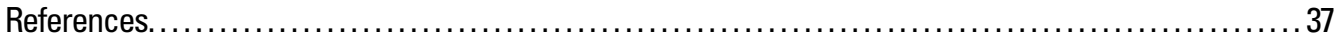

Appendixes

1. Comprehensive list of wetland staff gages and offsets to NGVD of $1929 \ldots \ldots \ldots \ldots 40$

2-11. Estimated area and volume of water corresponding to stage and depth below land surface elevation at palmetto fringe in:

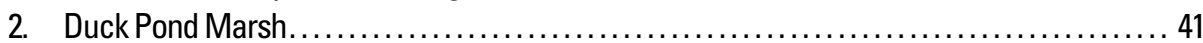

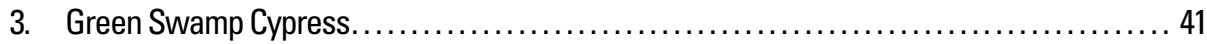

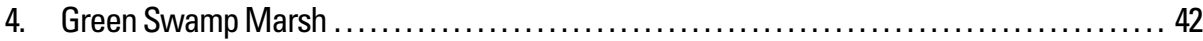

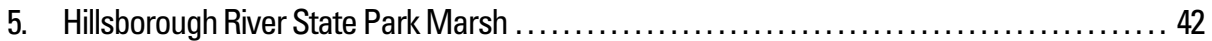

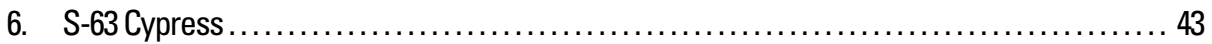

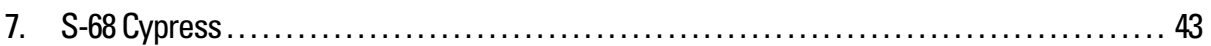

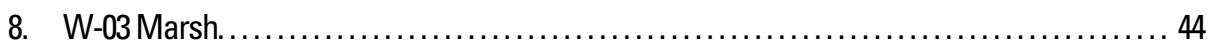

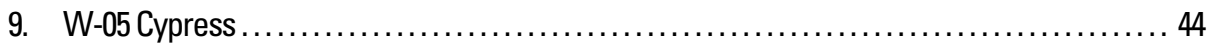

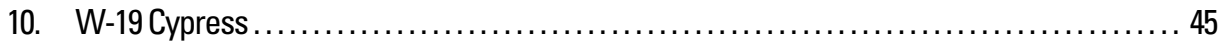

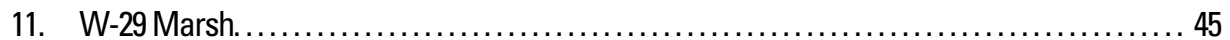

12. Names and status of wetland plants identified in fixed plots at wetland sites ....... 46

13. Comparison of National Wetlands Inventory and U.S. Geological Survey wetland

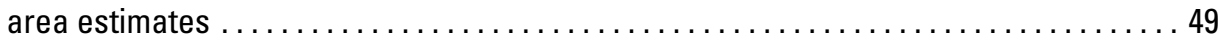




\section{Figures}

1. Map showing location of study wetlands in the northern Tampa Bay area, west-central Florida . . . . 6

2-11. Figures showing wetland bathymetric contours, density of bathymetric data points, and stage-volume and stage-area curves for:

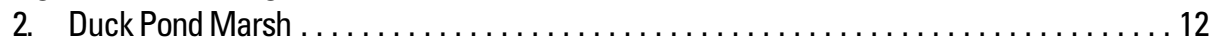

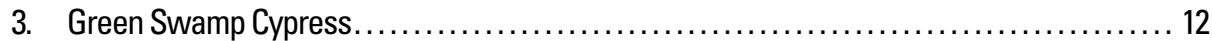

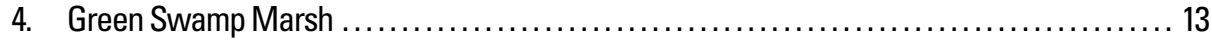

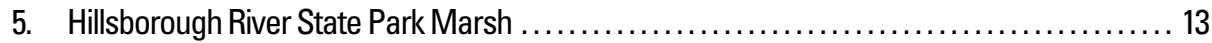

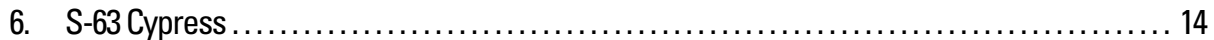

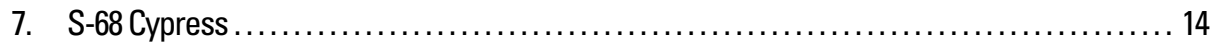

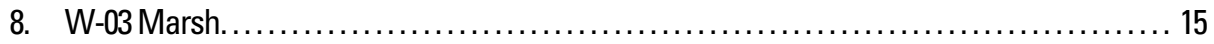

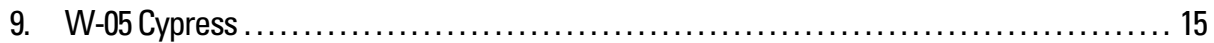

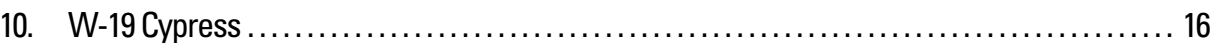

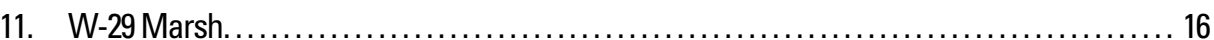

12-13. Maps showing contour lines developed for:

12. W-29 Marsh from all bathymetric data points, a subset of bathymetric data points along three transect lines, and a subset of bathymetric data points along three

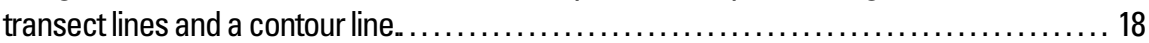

13. Green Swamp Marsh from all bathymetric data points, a subset of bathymetric data points along two transect lines, and a subset of bathymetric data points along two transect lines and a contour line........................................ 19

14-16. Graphs showing:

14. Effects of a reduced density of bathymetric data points at W-29 Marsh on stage-area

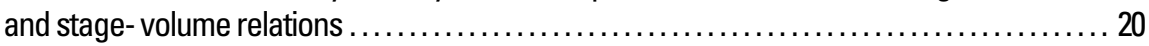

15. Effects of a reduced density of bathymetric data points at Green Swamp Marsh on stage-area and stage-volume relations..................................... 21

16. Changes in weekly average flooded area over time at Green Swamp Marsh and W-29 Marsh......................................................... 22

17. Map showing distribution and status of Pinus elliotiitrees in W-29 Marsh during

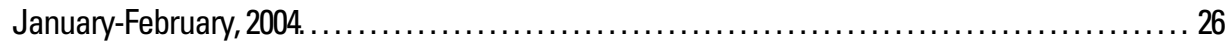

18-19. Graphs showing:

18. Inundated area at an impaired marsh and a natural marsh during an average year

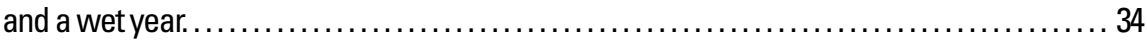

19. Duration of inundation of vegetation plots at an impaired marsh and a natural marsh during an average year and a wet year.... 


\section{Tables}

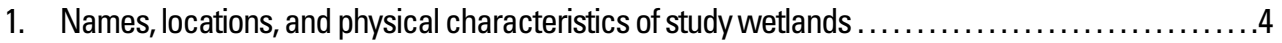

2. Indicators of normal pool elevation and elevation of palmetto fringe at wetland edge $\ldots \ldots \ldots \ldots \ldots .8$

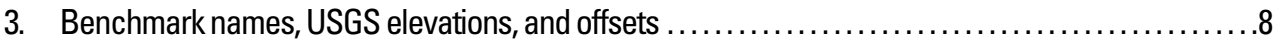

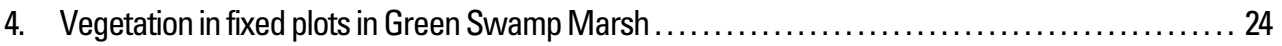

5. Vegetation in fixed plots in Hillsborough River State Park Marsh ........................... 24

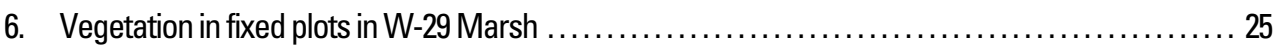

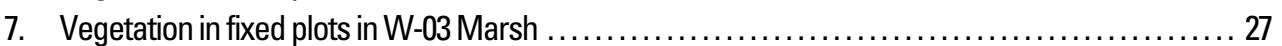

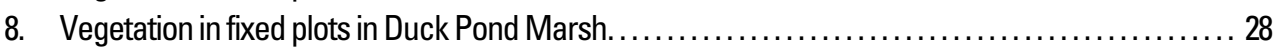

9. Vegetation in fixed plots in Green Swamp Cypress................................... 29

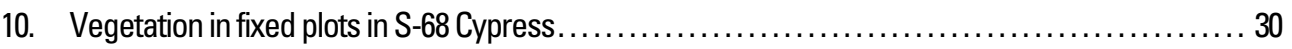

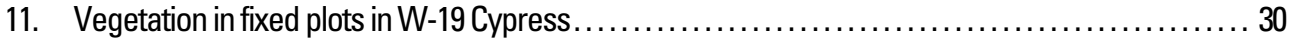

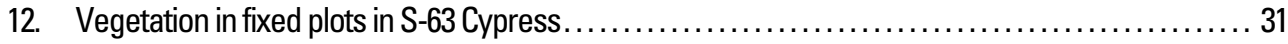

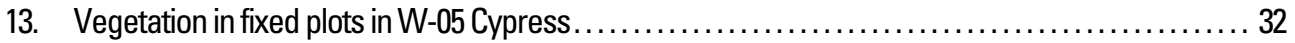

14. Elevation of vegetation plots and percent of wetland area inundated at specified elevations ...... 33

\section{Conversion Factors and Datums}

\begin{tabular}{rcl}
\hline Multiply & By & To obtain \\
\hline & Length & \\
acre-foot (acre-ft) & 1,233 & cubic meter \\
foot $(\mathrm{ft})$ & 0.3048 & meter \\
mile (mi) & 1.609 & kilometer \\
million gallons per day (Mgal/d) & 0.04381 & cubic meter per second \\
& Area & \\
acre & 0.4047 & hectare \\
square foot $\left(\mathrm{ft}^{2}\right)$ & 0.09290 & square meter \\
square mile $\left(\mathrm{mi}^{2}\right)$ & 2.590 & square kilometer \\
\hline
\end{tabular}

Vertical coordinate information is referenced to the "National Geodetic Vertical Datum of 1929 (NGVD of 1929)."

Horizontal coordinate information is referenced to the "North American Datum of 1927 (NAD 27)." 


\section{Acronyms and Additional Abbreviations}

\begin{tabular}{rll}
\hline CBR & Cross Bar Ranch Well Field \\
CCW & Cypress Creek Well Field \\
DBH & diameter at breast height \\
FDEP & Florida Department of Environmental Protection \\
DGPS & Differential Global Positioning System \\
ERP & Environmental Resource Permitting \\
FAC & facultative \\
FACW & facultative wet \\
FWS & U.S. Fish and Wildlife Service \\
GS & Green Swamp Wildlife Management Area \\
HRSP & Hillsborough River State Park \\
NTB & Northern Tampa Bay \\
NWI & National Wetlands Inventory \\
OBL & obligate \\
SWFWMD & Southwest Florida Water Management District \\
SWP & Jay B. Starkey Wilderness Park \\
TBW & Tampa Bay Water \\
TOPCON & Topcon Total Station \\
USGS & U.S. Geological Survey \\
WAP & Wetland Assessment Procedure \\
WUP & Water Use Permit \\
\hline & \\
\hline
\end{tabular}




\title{
Bathymetry and Vegetation in Isolated Marsh and Cypress Wetlands in the Northern Tampa Bay Area 2000-2004
}

\author{
By Kim H. Haag, Terrie M. Lee, and Donald C. Herndon
}

\section{Abstract}

Wetland bathymetry and vegetation mapping are two commonly used lines of evidence for assessing the hydrologic and ecologic status of expansive coastal and riverine wetlands. For small isolated freshwater wetlands, however, bathymetric data coupled with vegetation assessments are generally scarce, despite the prevalence of isolated wetlands in many regions of the United States and the recognized importance of topography as a control on inundation patterns and vegetation distribution.

In the northern Tampa Bay area of west-central Florida, bathymetry was mapped and vegetation was assessed in five marsh and five cypress wetlands. These 10 isolated wetlands were grouped into three categories based on the effects of ground-water withdrawals from regional municipal well fields: natural (no effect), impaired (drier than natural), and augmented (wetlands with artificially augmented water levels). Delineation of the wetland perimeter was a critical component for estimating wetland-surface area and stored water volume. The wetland perimeter was delineated by the presence of Serenoa repens (the "palmetto fringe") at 9 of the 10 sites. At the 10th site, where the palmetto fringe was absent, hydric-soils indicators were used to delineate the perimeter. Bathymetric data were collected using one or more techniques, depending on the physical characteristics of each wetland. Wetland stage was measured hourly using continuous stage recorders. Wetland vegetation was assessed semiannually for $21 / 2$ years in fixed plots located at three distinct elevations. Vegetation assessments were used to determine the community composition and the relative abundance of obligate, facultative wet, and facultative species at each elevation.

Bathymetry maps were generated, and stage-area and stage-volume relations were developed for all 10 wetlands. Bathymetric data sets containing a high density of data points collected at frequent and regular spatial intervals provided the most useful stage-area and stage-volume relations. Bathymetric maps of several wetlands also were generated using a low density of data points collected along transect lines or contour lines. In a comparative analysis of the three mapping approaches, stagearea and stage-volume relations based on transect data alone underestimated (by 50-100 percent over certain ranges of stage) the wetland area and volume compared to results using a high density of data points. Adding data points collected along one elevation contour below the wetland perimeter to the transect data set greatly improved the agreement of the resulting stagearea and stage-volume relations to the high-density mapping approach.

Stage-area relations and routinely monitored stage data were used to compare and contrast the average flooded area in a natural marsh and an impaired marsh over a 2 -year period. Vegetation assessments used together with flooded-area information provided the potential for extrapolating vegetation results from points or transects to wetlands as a whole. A comparison of the frequency of flooding of different areas of the wetland and the species composition in vegetation plots at different elevations indicated the dependence of vegetation on inundation frequency. Because of the broad tolerances of many wetlands plants to a range of inundation conditions, however, vegetation assessments alone provided less definitive evidence of the hydrologic differences between the two sites, and hydrologic changes occurring during the 2 years, than the floodedarea frequencies.

Combining flooded-area frequencies with vegetation assessments could provide a more versatile and insightful approach for determining the ecological status of wetlands than using vegetation and stage data alone. Flooded-area frequencies may further provide a useful approach for assessing the ecological status of wetlands where historical vegetation surveys and stage data are lacking. Comparing the contemporary floodedarea frequencies and vegetation in impaired or augmented wetlands to the flooded-area frequencies of natural wetlands with 


\section{Bathymetry and Vegetation in Isolated Marsh and Cypress Wetlands in the Northern Tampa Bay Area, 2000-2004}

similar geologic and climatic settings provides a method to assess the impacts of human activities on hydrology and ecology. The approach requires first determining flooded-area frequencies in a representative population of natural (or reference) wetlands. Because the variables are spatial, such comparisons can be used to interpret the extent of wetland mitigation achieved using augmentation, and to objectively assess the area of wetlands affected by human activities.

Bathymetric data, historical stage data, stage-area and stage-volume relations, and vegetation community assessment are all important tools for water managers tasked with assessing wetland status and the impacts of human activities on wetlands. Together these data sets can be used as tools to refine understanding and management of wetland systems.

\section{Introduction}

Hydrologic processes in wetlands give rise to the characteristic hydric soils and hydrophytic vegetation that define these complex ecosystems (Gosselink and Turner, 1978; Carter, 1986; Duever, 1988; National Research Council, 1995). The importance of wetland hydrology contrasts sharply with the relative lack of published data on the subject, and there are relatively few comprehensive studies that describe in detail the hydrologic characteristics of specific wetland types (Mitsch and Gosselink, 1993). Variations in inundation frequency, depth duration, and seasonality of water levels result in the distinctive habitat zonation found in wetlands. These hydrologic characteristics are influenced by topography and other physical features of the terrain. Yet despite the recognized importance of topography as a control on wetland hydrology and ecosystem structure, topographic data generally are not available for small wetlands (less than 10 acres) in isolated depressions (Winter, 1988; Wise and others, 2000; Brooks and Hayashi, 2002). In contrast, topographic data are more readily available for coastal marsh wetlands (Ramsey and others, 1998) where elevation contours that determine the frequency, duration, and depth of flooding have been assessed at large scales using remote sensing.

To describe the seasonal flooding cycle in small isolated wetlands, water depth is monitored over time at the deepest point in a wetland, and the water-level fluctuations at this point are assumed to be characteristic of the wetland feature as a whole. The validity of this assumption commonly goes untested because topographic (bathymetric) data rarely are available to describe the percentage of wetland area flooded at water levels below maximum depth (Ward, 1998). Water depth measured at a staff gage, although monitored regularly and often in conjunction with periodic vegetation assessments, provides little in the way of useful feedback to vegetation surveys unless the entire wetland is flooded. Even when water depth is measured at the site of a vegetation assessment, rarely is it related back to the water depth at the staff gage or at the deepest point. Bathymetric data also are a prerequisite to describing other facets of wetland hydrology. For example, the relations between water level (stage), wetland area, and volume are dependent on bathymetry, and bathymetric data are needed to describe wetland water budgets as well as to describe the error accompanying water-budget calculations.

Hydrologic characteristics have a fundamental influence on the spatial distribution of freshwater vegetation (Harris and Marshall, 1963; Spence, 1982; Schalles and Shure, 1989; Squires and van der Valk, 1992; Ross and others, 2003). Shifts in the wetland vegetation community composition are a primary line of evidence for assessing the ecological condition of wetlands in many types of wetland assessments (Bartoldus, 1999a,b, 2000). In turn, changes in the vegetation community commonly are used to indicate changes in the hydrologic conditions of wetlands. Inferring hydrologic trends based on changes in wetland plant communities has limitations, however, because a wetland plant community at a given point in time is reflective of conditions in the "recent" past but not necessarily those of the immediate present (Lewis, 2001) or the more distant past. Typically, there is a time lag between hydrologic alterations and changes in vegetation community composition (van der Valk and Welling, 1988). Furthermore, many wetland species are tolerant of well-drained soils, for if they were not they could not withstand the dry intervals that affect wetlands. Thus, the ability to discern patterns in vegetation related to alterations in wetland water level is complicated by the substantial variation and overlap of hydrologic tolerances of wetland vegetation (Squires and van der Valk, 1992).

Vegetation surveys used in conjunction with topographic data and stage data can improve substantially the ability to assess changes in the ecological status of wetlands. With topographic data, changes in water-level regime recorded at a staff gage can be extrapolated spatially, and vegetation assessments based on point or transect data can be considered in association with spatial patterns of inundation. A large number of isolated marsh and cypress wetlands are present in comparable geologic settings with similar water sources in the northern Tampa Bay (NTB) area. Many of these wetlands have historical water-level data and vegetation surveys. The addition of bathymetric data to these data sets provides a unique approach to investigate the complex relations between wetland bathymetry, depth-areavolume relations, and vegetation.

\section{Purpose and Scope}

The purpose of this report is to describe the bathymetry and vegetation of 10 isolated wetlands in the NTB area. Specifically, the report: (1) describes relations between wetland water level (stage), the area of inundation, and stored water volume; (2) compares several bathymetric data collection and analysis techniques; (3) describes wetland vegetation in relation to bathymetric contours and water depth; and (4) discusses the potential relation between vegetation and the frequency of inundation at different bathymetric contours. 
Bathymetric data were collected using one or more techniques, depending on the physical characteristics of the wetlands. Stage-area-volume relations were developed from U.S. Geological Survey (USGS) data collected during 20002004. Wetland vegetation was assessed in fixed plots semiannually over a $21 / 2$-year period. This report is part of a larger study of the effects of augmentation on hydrology, water quality, and ecology in isolated marsh and cypress wetlands in the NTB area. The study was conducted by the USGS in cooperation with Pinellas County, the Southwest Florida Water Management District (SWFWMD), and Tampa Bay Water.

\section{Background}

Freshwater wetlands are a widespread and distinctive feature of the Florida landscape (Darst and others, 1995). Wetlands give rise to a unique vegetative community, and their value as fish and wildlife habitat is considerable (Hart and Newman, 1995). In west-central Florida, freshwater wetlands consist of both forested and non-forested types, including riverine swamps, lacustrine swamps, cypress domes, marshes, and wet prairies (Southwest Florida Water Management District, 1999). A 1986 inventory of 71 square miles $\left(\mathrm{mi}^{2}\right)$ in the NTB area indicated that wetlands account for about 23 percent of the total acreage surveyed.

A substantial percentage ( 92 percent) of the total number of wetlands in the NTB area are isolated wetlands, and isolated wetlands compose 68 percent of the total wetland acreage. Moreover, small isolated wetlands less than 5 acres in size account for 79 percent of the total number of isolated wetlands and 34 percent of the total isolated wetland acreage (Manuel Lopez, SWFWMD, written commun., 2002). The term "isolated wetland" is not a precise scientific or regulatory term, but in general is used to define a wetland that lacks a surface outlet to a downstream river (Leibowitz, 2003). Many isolated wetlands, however, have natural areas of outflow during flood conditions when stage exceeds the elevation of the wetland perimeter. Likewise, isolated wetlands also can receive inflow generated by outflow from an upgradient wetland (Winter and LaBaugh, 2003). Wetlands develop these intermittent connections at recurrence intervals that can be predicted based on a knowledge of precipitation patterns and other climatic variables (Winter and LaBaugh, 2003).

A majority of isolated marshes and stillwater cypress swamps in west-central Florida are supplied with water from precipitation and shallow, acidic ground water (Myers and Ewel, 1990). In these isolated wetlands, where the water table approaches land surface seasonally under natural conditions, the hydroperiod is largely determined by differences between precipitation and evapotranspiration, and is mediated by geology and topography. Small changes in wetland stage can cause large changes in wetland-surface area, because there is little local topographic relief. Persistent changes in wetland water levels, as a result of changes in rainfall or human activities, can in turn cause a substantial change in the vegetation of hundreds or thousands of acres of land in the NTB area.
Rapid increases in Florida's west coast population during 1970-2000 have had two important effects on isolated wetlands. First, land development has caused elimination or fragmentation of wetlands, reducing their effective size and associated habitat value for wildlife. Second, the demand for potable water supply has increased the ground-water withdrawal rate, measurably lowering the potentiometric surface in the Upper Floridan aquifer. A lower potentiometric-surface elevation in the Upper Floridan aquifer reduces the potentiometric surface of the surficial aquifer, and lowers the stage (surface-water elevation) of wetlands in nearby areas (Berryman and Henigar, Inc., 1995). On municipal well fields, wetlands close to production wells may exhibit substantially reduced surface-water levels with much shorter and less frequent inundation than wetlands not influenced by human activities (Biological Research Associates, Inc., 1996). Effects of decreased depth and frequency of inundation on wetland vegetation range from minimal to severe. Changes in wetland vegetation community composition can occur, and there may be associated changes in habitat value for wildlife (Dooris and others, 1990; $\mathrm{CH}_{2} \mathrm{M}$ HILL, 1996). Oxidation and compaction of exposed wetlands soils causes loss of root support and subsequent treefall in cypress wetlands (Rochow, 1985, 1994). Treefall in these systems opens the canopy and facilitates encroachment of upland species.

Protecting the quality of Florida's wetlands is the responsibility of the Florida Department of Environmental Protection (FDEP). The FDEP Environmental Resource Permitting (ERP) Program is designed to ensure that activities in uplands, wetlands, and other surface waters do not degrade water quality or degrade habitat for aquatic or wetland-dependent wildlife. The SWFWMD shares the responsibility of implementing the ERP Program in west-central Florida. Water-use activities by regional water utilities such as Tampa Bay Water are regulated by the SWFWMD under the Consolidated Water Use Permit (WUP) Program. As part of Tampa Bay Water's WUP for its 11 regional well fields, Tampa Bay Water developed an Environmental Management Plan (EMP). The EMP addresses management of the well fields, and proposes mitigation alternatives to regain wetland values that have been lost due to ground-water withdrawals. Augmentation (rehydration) with ground water is one mitigation alternative that has been used long-term (for more than 15 years) in about 15 wetlands on well fields in the NTB area (John Emery, SWFWMD, oral commun., 2005).

\section{Site Selection}

The isolated wetlands (five marsh and five cypress) selected for study range in size from about 1-9 acres (table 1), and maximum depths range from about 1-8 feet (ft). Isolated wetlands of this size are common throughout the NTB area. Wetland sites with existing data collection programs were given preference in the selection process. 
Table 1. Names, locations, and physical characteristics of study wetlands.

[USGS, U.S. Geological Survey; N, north; W, west; sec, section; T, township; S, south; R, range; SWFWMD, Southwest Florida Water Management District; latitude and longitude in degrees ( ${ }^{\circ}$ ), minutes $(')$, and seconds $(")]$

\begin{tabular}{|c|c|c|c|c|c|c|c|c|c|c|c|}
\hline Wetland name & $\begin{array}{c}\text { USGS } \\
\text { wetland } \\
\text { name }\end{array}$ & Alternate names & $\begin{array}{l}\text { Period } \\
\text { of hydrologic } \\
\text { record }\end{array}$ & County & Latitude & Longitude & Location ${ }^{1}$ & $\begin{array}{c}\text { Size } \\
\text { (acres) }\end{array}$ & $\begin{array}{l}\text { Maximum } \\
\text { depth } \\
\text { (feet) }\end{array}$ & $\begin{array}{l}\text { Mean } \\
\text { depth } \\
\text { (feet) }\end{array}$ & $\begin{array}{l}\text { Wetland } \\
\text { type }\end{array}$ \\
\hline $\begin{array}{l}\text { Cross Bar Ranch } \\
\text { Well Field } \\
\text { Duck Pond Marsh }\end{array}$ & $\begin{array}{l}\text { Duck } \\
\text { Pond } \\
\text { Marsh }\end{array}$ & Q-04 & 1978-present & Pasco & $28^{\circ} 21^{\prime} 59^{\prime \prime} \mathrm{N}$ & $82^{\circ} 28^{\prime} 02^{\prime \prime} \mathrm{W}$ & $\begin{array}{l}\text { sec. } 25, \text { T. } 24 \text { S., } \\
\text { R. } 18 \text { E, } \\
\text { Ehren, FL }\end{array}$ & 5.2 & 8.13 & 3.20 & Augmented \\
\hline $\begin{array}{l}\text { Green Swamp } \\
\text { Wildlife Management } \\
\text { Area Cypress }\end{array}$ & $\begin{array}{l}\text { GS } \\
\text { Cypress }\end{array}$ & $\begin{array}{l}\text { Green Swamp 5; } \\
\text { SWFWMD } \\
\text { Station } 541\end{array}$ & 1979-present & Sumter & $28^{\circ} 24^{\prime} 47^{\prime \prime} \mathrm{N}$ & $81^{\circ} 57^{\prime} 40^{\prime \prime} \mathrm{W}$ & $\begin{array}{l}\text { sec. 12, T. } 24 \text { S., } \\
\text { R. } 23 \text { E., } \\
\text { Bay Lake, FL }\end{array}$ & 1.7 & 1.69 & 0.46 & Natural \\
\hline $\begin{array}{l}\text { Green Swamp } \\
\text { Wildlife Management } \\
\text { Area Marsh }\end{array}$ & $\begin{array}{l}\text { GS } \\
\text { Marsh }\end{array}$ & $\begin{array}{l}\text { SWFWMD } \\
\text { Station } 605\end{array}$ & 1995-present & Sumter & $28^{\circ} 21^{\prime} 16^{\prime \prime} \mathrm{N}$ & $82^{\circ} 01^{\prime} 02^{\prime \prime} \mathrm{W}$ & $\begin{array}{l}\text { sec. } 33, \text { T. } 24 \text { S., } \\
\text { R. } 23 \text { E., } \\
\text { Branchborough, FL }\end{array}$ & 1.6 & 1.07 & 0.62 & Natural \\
\hline $\begin{array}{l}\text { Hillsborough } \\
\text { River State Park } \\
\text { Marsh }\end{array}$ & $\begin{array}{l}\text { HRSP } \\
\text { Marsh }\end{array}$ & $\begin{array}{l}\text { SWFWMD } \\
\text { Station } 378\end{array}$ & 1977-present & $\begin{array}{c}\text { Hills- } \\
\text { borough }\end{array}$ & $28^{\circ} 08^{\prime} 49^{\prime \prime} \mathrm{N}$ & $82^{\circ} 13^{\prime} 41^{\prime \prime} \mathrm{W}$ & $\begin{array}{l}\text { sec. } 8, \text { T. } 27 \text { S., } \\
\text { R. } 21 \text { E., } \\
\text { Zephyrhills, FL }\end{array}$ & 2.2 & 2.65 & 0.67 & Natural \\
\hline $\begin{array}{l}\text { Jay B. Starkey } \\
\text { Wilderness Park } \\
\text { S-63 Cypress }\end{array}$ & $\begin{array}{l}\text { S-63 } \\
\text { Cypress }\end{array}$ & -- & 1983-present & Pasco & $28^{\circ} 14^{\prime} 55^{\prime \prime} \mathrm{N}$ & $82^{\circ} 35^{\prime} 00^{\prime \prime} \mathrm{W}$ & $\begin{array}{l}\text { sec. 2, T. } 26 \text { S., } \\
\text { R. 17 E., } \\
\text { Odessa, FL }\end{array}$ & 1.3 & 1.47 & 0.58 & Augmented \\
\hline $\begin{array}{l}\text { Jay B. Starkey } \\
\text { Wilderness Park } \\
\text { S-68 Cypress }\end{array}$ & $\begin{array}{l}\text { S-68 } \\
\text { Cypress }\end{array}$ & $\begin{array}{l}\text { STWF-DD; } \\
\text { SWFWMD } \\
\text { Station } 209\end{array}$ & 1983-present & Pasco & $28^{\circ} 14^{\prime} 21^{\prime \prime} \mathrm{N}$ & $82^{\circ} 34^{\prime} 31^{\prime \prime} \mathrm{W}$ & $\begin{array}{l}\text { sec. 11, T. } 26 \text { S., } \\
\text { R. 17 E., } \\
\text { Odessa, FL }\end{array}$ & 5.8 & 1.55 & 0.79 & Natural \\
\hline $\begin{array}{l}\text { Cypress Creek } \\
\text { Well Field } \\
\text { W-03 Marsh }\end{array}$ & $\begin{array}{l}\text { W-03 } \\
\text { Marsh }\end{array}$ & $\begin{array}{l}\text { C-2 Marsh; } \\
\text { SWFWMD } \\
\text { Station } 482\end{array}$ & 1978-present & Pasco & $28^{\circ} 18^{\prime} 13^{\prime \prime} \mathrm{N}$ & $82^{\circ} 22^{\prime} 40^{\prime \prime} \mathrm{W}$ & $\begin{array}{l}\text { sec. 14, T. } 25 \text { S., } \\
\text { R. 19 E., } \\
\text { Ehren, FL }\end{array}$ & 7.4 & 5.44 & 1.89 & Augmented \\
\hline $\begin{array}{l}\text { Cypress Creek } \\
\text { Well Field } \\
\text { W-05 Cypress }\end{array}$ & $\begin{array}{l}\text { W-05 } \\
\text { Cypress }\end{array}$ & $\begin{array}{l}\text { T-1 Cypress Head; } \\
\text { CCWF A }\end{array}$ & 1978-present & Pasco & $28^{\circ} 18^{\prime} 18^{\prime \prime} \mathrm{N}$ & $82^{\circ} 22^{\prime} 55^{\prime \prime} \mathrm{W}$ & $\begin{array}{l}\text { sec. 14, T. } 25 \text { S., } \\
\text { R. 19 E, } \\
\text { Ehren, FL }\end{array}$ & 8.8 & 2.11 & 0.52 & Augmented \\
\hline $\begin{array}{l}\text { Cypress Creek } \\
\text { Well Field } \\
\text { W-19 Cypress }\end{array}$ & $\begin{array}{l}\text { W-19 } \\
\text { Cypress }\end{array}$ & C-10 Cypress Head & 1978-present & Pasco & $28^{\circ} 16^{\prime} 42^{\prime \prime} \mathrm{N}$ & $82^{\circ} 23^{\prime} 52^{\prime \prime} \mathrm{W}$ & $\begin{array}{l}\text { sec. } 27, \text { T. } 25 \text { S., } \\
\text { R. } 19 \text { E, } \\
\text { Ehren, FL }\end{array}$ & 2.1 & 2.70 & 1.08 & Impaired \\
\hline $\begin{array}{l}\text { Cypress Creek } \\
\text { Well Field } \\
\text { W-29 Marsh }\end{array}$ & $\begin{array}{l}\text { W-29 } \\
\text { Marsh }\end{array}$ & $\begin{array}{l}\text { Cottonmouth Marsh; } \\
\text { Rattlesnake Marsh }\end{array}$ & 1978-present & Pasco & $28^{\circ} 17^{\prime} 54^{\prime \prime} \mathrm{N}$ & $82^{\circ} 23^{\prime} 13^{\prime \prime} \mathrm{W}$ & $\begin{array}{l}\text { sec. 22, T. } 25 \text { S., } \\
\text { R. 19 E., } \\
\text { Ehren, FL }\end{array}$ & 6.5 & 2.76 & 1.44 & Impaired \\
\hline
\end{tabular}

${ }^{1}$ USGS 1:24,000 topographic map name. 
Three principal environmental conditions, or wetland types, are defined in the context of this investigation to describe the 10 study wetlands in the NTB area:

- Natural wetlands are defined as being unaffected or minimally affected by human activities including ground-water withdrawal. Four wetlands (two marsh and two cypress) were chosen to characterize the hydrologic conditions and vegetation of natural wetlands within the NTB area.

- Impaired wetlands are defined as wetlands that have been affected by ground-water withdrawals for several years and typically are dry for a longer period of the year than natural wetlands. Two wetlands (one marsh and one cypress) were selected to characterize the hydrologic conditions and vegetation of impaired wetlands within the NTB area.

- Augmented wetlands are defined as wetlands that have been affected by ground-water withdrawal and that have been augmented with ground water for at least 15 years. Four augmented wetlands (two marsh and two cypress) were selected to characterize the hydrologic conditions and vegetation of augmented wetlands within the NTB area.

\section{Description of the Study Area}

The NTB area encompasses about 1,800 $\mathrm{mi}^{2}$ of west-central Florida, including parts of Hernando, Hillsborough, Lake, Pasco, Polk, Pinellas, and Sumter counties (fig. 1). All 10 study sites are within the NTB area, and all are located either in well fields or on publicly owned lands (wildlife management areas or parks) in two physiographic regions (fig. 1). These regions (Gulf Coast Lowlands and Western Valley) (White, 1970) are characterized by a relatively high water table and are underlain by the Upper Floridan aquifer, which is semi-confined or unconfined in the study area. Land use and human activities in the vicinity of the study sites are described briefly.

The Cross Bar Ranch Well Field (CBR) encompasses about $12.5 \mathrm{mi}^{2}$ of land in north-central Pasco County (fig. 1). The CBR has been in production since 1980, and averages about 20 million gallons per day (Mgal/d) since 1996 (Biological Research Associates, Inc., 2001). The CBR is a multi-use facility; some of the CBR is conservation area, managed for wildlife, and about 45 percent of the acreage is cultivated as a pine plantation. There are several lakes and ponds on the property as well as wet prairies, marshes, and cypress ponds. Some wetlands have been augmented since the 1980s (Biological Research Associates, Inc., 2001), including Duck Pond Marsh (augmented since 1987) (fig. 1).

The Cypress Creek Well Field (CCW) encompasses about $7.7 \mathrm{mi}^{2}$ of land in central Pasco County (fig. 1). The land within the well field is in a relatively natural condition and is used as a wilderness park. The property has numerous isolated marsh and cypress wetlands, and the stream bed of historical Cypress Creek has been dry for long periods during recent years (Reynolds, Smith \& Hills, Inc., 2001). In areas surrounding the well field, land-use activities include ongoing residential development and agriculture. The $\mathrm{CCW}$ has been in production since 1976 and produces about $30 \mathrm{Mgal} / \mathrm{d}$ from the Upper Floridan aquifer (Reynolds, Smith \& Hills, Inc., 2001). Many of the wetlands on the CCW have been affected by declining groundwater levels, and some of them have been augmented for more than 20 years (Berryman and Henigar, 1995; Rochow, 1998; Reynolds, Smith \& Hills, Inc., 2001). Four study sites are located in the CCW: W-03 Marsh (augmented since 1979), W-05 Cypress (augmented since 1978), W-19 Cypress (impaired), and W-29 Marsh (impaired) (fig. 1).

The Green Swamp Wildlife Management Area (GS), previously know as the Green Swamp Flood Detention Area, encompasses about $75 \mathrm{mi}^{2}$ in Hernando, Lake, Pasco, Polk, and Sumter Counties (fig. 1). There is little development of the ground-water resource in this area, and surface-water levels are largely unaffected by human activities. Wetlands cover about one-third of the GS, and much of the remainder is covered in natural pine flatwoods. Natural cypress wetlands are extensive, whereas marsh wetlands cover less than 1 percent of the GS (Southwest Florida Water Management District, 1985). Several long-term wetland monitoring sites have been established and monitored by the SWFWMD, and these sites can be used to characterize conditions in natural wetlands (Rochow and Lopez, 1984). Two natural study wetlands are located in the GS: Green Swamp Marsh and Green Swamp Cypress (fig. 1).

The Hillsborough River State Park (HRSP) in northeastern Hillsborough County (fig. 1) encompasses about $6 \mathrm{mi}^{2}$ of pine flatwoods and live oak hammocks interspersed with natural marsh wetlands; surface-water levels are largely unaffected by human activity. The Hillsborough River is bordered by riverine wetlands, and flows through the western part of the Park. One natural wetland (Hillsborough River State Park Marsh) was selected as a study site in HRSP (fig. 1).

The Jay B. Starkey Wilderness Park (SWP) is located in southwestern Pasco County and encompasses about $13 \mathrm{mi}^{2}$ (fig. 1). The Park includes an operational well field (Starkey Well Field), as well as pine flatwoods, sandhills, hardwood hammock, freshwater marshes, cypress ponds, and two bands of riverine swamp associated with the Anclote and Pithlachascotee Rivers. The well field began production in 1974. Some wetland ecosystems have been affected by well-field development, whereas others have not (Rochow, 1998; Berryman and Henigar, 2001). Two study sites, S-63 Cypress (augmented since 1990) and S-68 Cypress (natural), are located in different parts of SWP (fig. 1).

\section{Acknowledgments}

Lauren Pusateri of the USGS, Tampa, provided valuable assistance with many aspects of data collection. The authors are grateful to Ted Rochow and David Carr of the SWFWMD for their contributions to identifying vegetation and increasing our understanding of normal pool indicators. Melanie Darst, Patty Fesmire, Michael Hancock, Warren Hogg, Helen Light, Ted Rochow, Donald Rosenberry, and Dave Slonena provided helpful reviews of the report. 


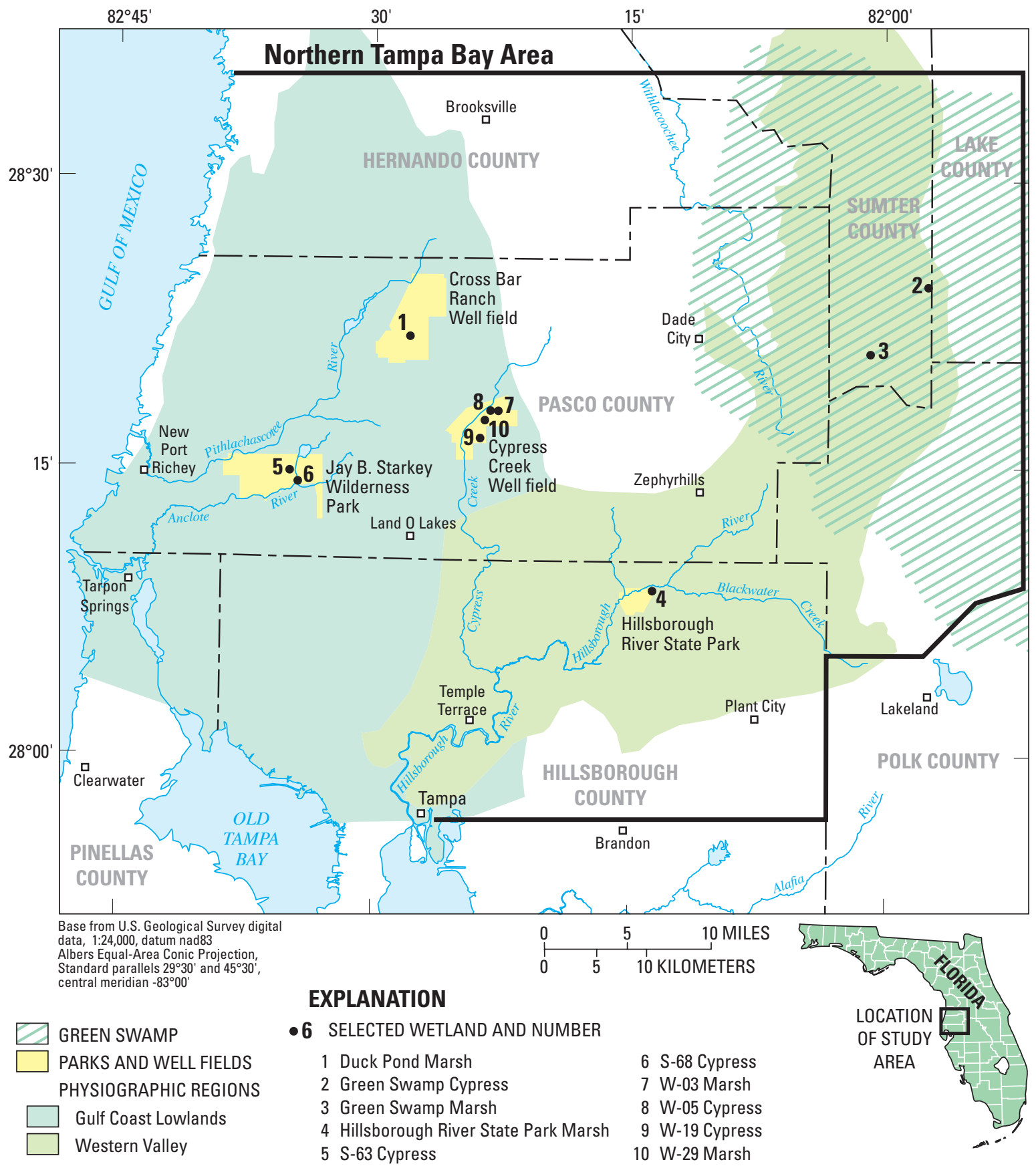

Figure 1. Location of study wetlands in the northern Tampa Bay area, west-central Florida. 


\section{Methods of Data Collection and Analysis}

The delineation of the wetland perimeter at each study site was a prerequisite for all subsequent data collection. Once the wetland perimeter was delineated, the perimeter elevation was determined. Wetland stage was measured at staff gages, and bathymetric data were collected throughout the interior of each wetland using one or more approaches. Bathymetric contour maps were drawn, and wetland area and stored water volume were calculated. The potential effect of different mapping approaches on calculated wetland area and water volume estimates was investigated at two wetland sites. Vegetation was identified to species, and relative abundance was determined semiannually in replicate fixed plots at known elevations at all study sites.

\section{Delineation of the Wetland Perimeter and Determination of Perimeter Elevations}

The wetland perimeter encompasses the maximum areal extent of a wetland. By definition, when water reaches the wetland perimeter, it is 100 percent inundated. The presence of Serenoa repens (saw palmetto) is commonly used to delineate wetland perimeters in Florida because this long-lived terrestrial shrub cannot survive inundation of its prostrate trunks for more than a few weeks. Therefore, the presence of saw palmetto at a particular elevation indicates that water is rarely at land surface above that point. Nine of the 10 study wetlands (excluding Duck Pond Marsh) are partially or completely surrounded by saw palmetto. As a result, the palmetto fringe at these sites was defined as the wetland perimeter. Perimeter coordinates were collected at approximately 30-ft intervals using a hand-held Garmin eTrex Legend Differential Global Position System (DGPS) unit. After plotting the DGPS data points using Arcview Geographic Information System software, the location of the entire perimeter was then interpolated.

The perimeter elevation for 9 of the 10 study wetlands was determined by the SWFWMD as a part of an ongoing study of vegetative "normal-pool" indicators in the NTB area. The concept of a normal pool was developed by the SWFWMD to establish a standard elevation datum that would facilitate comparisons of hydrology between wetlands (Mike Hancock, SWFWMD, written commun., 2004). SWFWMD determined in their study that the normal pool elevation of a cypress wetland can be identified consistently by the elevations of three vegetative normal pool indicators: the inflection point on the buttress of cypress trees (Taxodium spp.); the lower limit of epiphytic bryophytes (the moss collar) growing on cypress trees; and the elevation of the root crowns of mature specimens of Lyonia lucida on cypress trees (Carr and Rochow, 2004). As a part of their study, SWFWMD made concurrent measurements of the elevations of the cypress normal pool indicators and the rooted base of Serenoa repens (the "saw palmetto fringe") at those sites where the indicators and the palmetto fringe were both present. The SWFWMD determined that the cypress indicators at hydrologically unaltered wetlands are consistently $0.24 \mathrm{ft}$ above the median elevation of the rooted base of Serenoa repens (Carr and Rochow, 2004). This consistent difference means that in the NTB area, the elevation of a cypress normal pool indicator can be measured to determine the elevation of the palmetto fringe.

The SWFWMD made five elevation measurements of the normal pool indicator at each of these nine sites, and the median value was reported (table 2). The SWFWMD surveyed the elevation of the normal pool indicators from existing benchmarks (tables 2, 3). At some sites (Duck Pond Marsh, Hillsborough River State Park Marsh, W-19 Cypress, and W-29 Cypress), these elevations did not agree with independent surveys by USGS from other benchmarks. Corrections (offsets) were applied to SWFWMD benchmark elevations at these sites because of the discrepancy between benchmarks to establish consistency with bathymetric and other data collected for this study. For this report, all elevations are relative to the National Geodetic Vertical Datum of 1929 (NGVD of 1929).

The location and the elevation of the wetland perimeter at Duck Pond Marsh was determined by the presence of hydric soils (Hurt and others, 2000), because land-management practices have eliminated saw palmetto from the area. Hydric soils form under conditions of saturation such that anaerobic conditions develop and persist over time (Richardson and Vepraskas, 2001). Soil core samples collected by the SWFWMD along a single transect at several distances onshore at Duck Pond Marsh were analyzed to determine the vertical location of hydric soils (David Carr, SWFWMD, oral commun., 2003). Markers were placed along the transect at locations where hydric soils were present 3, 6, and 12 inches below land surface. Using Topcon Total Station Model GTS-303D surveying equipment (Topcon), the land-surface elevation at each soil depth was determined, and from the three landsurface elevations, three elevations of hydric-soils indicators were determined. The mean of these three elevations was selected to represent the elevation at which 100 percent of the wetland would be inundated. This elevation then was used to determine the perimeter of the wetland at Duck Pond Marsh. Pairs of elevation points were measured around the edge of the wetland using the Topcon, with each pair consisting of one upslope measurement and one downslope measurement from the 100-percent inundation elevation. The actual perimeter points were then estimated by interpolation between the pairs of values.

\section{Measurement of Wetland Stage and Collection of Bathymetric Data}

Wetland stage has been monitored for at least a decade at each of the 10 wetland sites, and up to 25 years at some sites. At each site, wetland stage could be measured by reading the water level on a staff gage located within the wetland. Three of the 10 wetlands had more than one staff gage. For example, three staff gages were present in Duck Pond Marsh at different distances from the wetland perimeter. It should be noted that from time to time, staff gages are added or removed by agencies 
Table 2. Indicators of normal pool elevation and elevation of palmetto fringe at wetland edge.

[SWFWMD, Southwest Florida Water Management District; USGS, U.S. Geological Survey; na, not applicable; all elevations in feet above NGVD of 1929]

\begin{tabular}{|c|c|c|c|c|c|}
\hline Wetland name & $\begin{array}{l}\text { Normal pool } \\
\text { indicators }\end{array}$ & $\begin{array}{l}\text { SWFWMD } \\
\text { elevation of } \\
\text { normal pool } \\
\text { indicators }{ }^{1}\end{array}$ & $\begin{array}{l}\text { Palmetto fringe } \\
\text { elevation derived } \\
\text { from normal } \\
\text { pool indicators }\end{array}$ & $\begin{array}{c}\text { Offset from } \\
\text { SWFWMD } \\
\text { elevation to } \\
\text { USGS elevation }\end{array}$ & $\begin{array}{c}\text { USGS elevation } \\
\text { of wetland } \\
\text { perimeter } \\
\text { at wetland edge }\end{array}$ \\
\hline Duck Pond Marsh & Hydric Soils & na & na & na & 70.48 \\
\hline Green Swamp Cypress & Lyonia & 98.80 & 98.56 & ${ }^{2} 0$ & 98.56 \\
\hline Green Swamp Marsh & Palmetto Fringe & 93.30 & 93.30 & 0 & 93.30 \\
\hline $\begin{array}{l}\text { Hillsborough River } \\
\text { State Park Marsh }\end{array}$ & Palmetto Fringe & 46.08 & 46.08 & 0.27 & 46.35 \\
\hline S-63 Cypress & Lyonia & 42.56 & 42.32 & 0 & 42.32 \\
\hline S-68 Cypress & Lyonia & 43.90 & 43.66 & 0 & 43.66 \\
\hline W-03 Marsh & Palmetto Fringe & 72.44 & 72.44 & 0 & 72.44 \\
\hline W-05 Cypress & Buttress Swelling & 71.71 & 71.47 & 0 & 71.47 \\
\hline W-19 Cypress & Buttress Swelling & 63.47 & 63.23 & na & 63.23 \\
\hline W-29 Marsh & Palmetto Fringe & 69.86 & 69.86 & 0.06 & 69.92 \\
\hline
\end{tabular}

${ }^{1}$ Reported elevation is the median of five elevation measurements.

${ }^{2}$ SWFWMD field notes unavailable; offset assumed to be 0 .

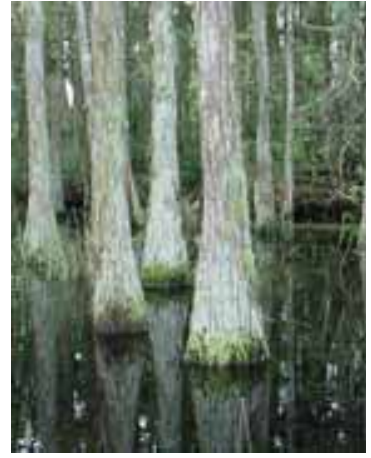

Shade and deep water inhibit the growth of aquatic plants in the center of $\mathrm{S}-68$, a natural cypress wetland.

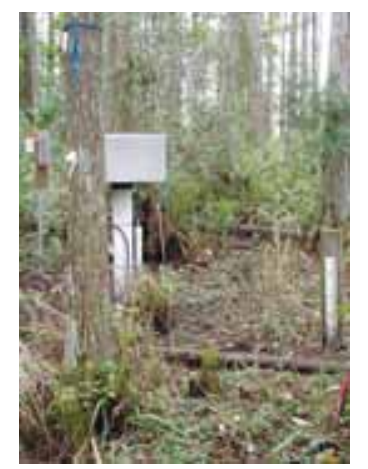

An open canopy and shallow water foster the dense growth of understory plants at S-63, an augmented cypress wetland.
Table 3. Benchmark names, USGS elevations, and offsets.

[USGS, U.S. Geological Survey; SWFWMD, Southwest Florida Water Management District; TBM, temporary benchmark; RM, reference mark]

\begin{tabular}{l|lcl}
\hline \multicolumn{1}{c|}{ Wetland name } & \multicolumn{1}{|c}{ Benchmark name } & $\begin{array}{c}\text { Elevation' } \\
\text { of } \\
\text { benchmark }\end{array}$ & Offset $^{2}$ \\
\hline Duck Pond Marsh & USGS Well A-2 deep & 78.16 & 0 \\
Green Swamp Cypress & SWFWMD TBM 25-24-18-2 & 75.64 & 0.05 \\
Green Swamp Marsh & SWFWMD TBM 12-24-23-1 & 99.77 & 0 \\
Hillsborough River State & SWFWMD TBM 33-24-23-1 & 96.00 & 0 \\
Park Marsh & USGS RM 9 & 43.05 & 0 \\
S-63 Cypress & SWFWMD TBM 8-27-21-3 & 48.83 & 0.27 \\
S-68 Cypress & SWFWMD TBM 02-26-17-6 & 43.39 & 0 \\
W-03 Marsh & SWFWMD TBM 11-26-17-18 & 44.83 & 0 \\
W-05 Cypress & SWFWMD TBM 14-25-19-5 & 76.99 & 0 \\
W-19 Cypress & SWFWMD TBM 14-25-19-2 & 72.53 & 0 \\
& SWFWMD TBM 27-25-19-2 & 67.96 & 0 \\
W-29 Marsh & SWFWMD TBM 27-25-19-7 & 64.84 & -0.04 \\
& SWFWMD TBM 23-25-19-5 & 73.77 & 0 \\
\hline & SWFWMD TBM 22-25-19-9 & 70.67 & 0.06 \\
\hline
\end{tabular}

\footnotetext{
${ }^{1}$ All elevations in feet above NGVD of 1929.

${ }^{2}$ Offsets to be applied to SWFWMD benchmark elevations for compatibility with USGS elevations presented in this report.
} 
monitoring wetlands. To avoid confusion in this study, each staff gage was uniquely identified using the reading at the top of the staff gage plate, and the locations of all staff gages at the 10 wetlands were determined using DGPS (see app. 1). Elevation surveys were run to all staff gages from well-defined benchmarks (table 3). If needed, staff gages were assigned correction factors (offsets) based on the USGS surveying results to produce stage expressed as elevation in feet above NGVD of 1929. Wetland stage was measured hourly with continuous stage recorders in each of the study wetlands using established methods (Buchanan and Somers, 1982).

Detailed bathymetric maps provide the basis for defining the relation between stage, area of inundation, and stored volume of water in a wetland. Bathymetry of the 10 study wetlands was described using two principal approaches, or a combination of the two, as described in detail in the following paragraphs. More than one approach was needed to collect bathymetric data because the wetlands differ in their depth, size, extent of inundation, and density of vegetation. Methods for surveying the land-surface elevation or topography of the wetlands were chosen based on available line of sight (an unobstructed path across which measurements can be made) and the depth of water present in each wetland.

At the five sites where there was an available line of sight (W-29 Marsh, HRSP Marsh, GS Marsh, W-19 Cypress, S-63 Cypress), Topcon was used to survey land-surface elevations. The Topcon tripod was set up in the interior of the wetland and a point of known location, determined by DGPS, was surveyed to determine the location of the tripod. Then elevation data points were collected approximately 20-30 ft apart as the rod was moved throughout the wetland. The rod was moved either along a grid pattern, or in a radial pattern moving away from the Topcon tripod. The tripod was set up multiple times in different locations if the wetland was large, or if the line of sight was limited.

At the three sites where water was present over approximately 100 percent of the wetland area at the time of data collection (GS Cypress, S-68 Cypress, and Duck Pond Marsh), DGPS and the measured depth of water below a known elevation were used to determine the elevation of the land surface along lines transecting the wetlands. The horizontal locations of points along the transect lines usually were determined using DGPS. In parts of these wetlands where the canopy was dense and the DGPS signal could not be detected, a compass was used to obtain direction and a measuring tape was used to determine the horizontal distance from a known location. At GS Cypress and S-68 Cypress, which are both natural wetlands, flocculent bottom sediment was scant and the depth of water was measured directly to the sandy bottom using a graduated rod. Water depth subtracted from the wetland stage provided the elevation of points on the transect lines. At Duck Pond Marsh, which contained deep flocculent sediments characteristic of augmented sites, the water was too deep to visualize the top of the sediment layer. As a result, the water depth was measured using a graduated rope attached to a Secchi disk, which was lowered to the top of the flocculent sediment layer.
At the two remaining sites (W-03 Marsh and W-05 Cypress), the water surface did not cover the entire wetland and the line of sight was limited in some areas, so a combination of approaches was used. The Topcon was used to survey the elevation of dry areas and areas with a clear line of sight. In wet areas without a clear line of sight, the depth below the water surface was measured with a graduated rod. At W-03 Marsh, the northwestern part of the wetland had poor access because of very dense shrub vegetation and data points are sparse. At W-05 Cypress, there was a deep layer of flocculent bottom material. At this site, two depths of water were determined at each point (depth to hard bottom and depth to the top of the flocculent layer), and these depths were averaged.

The Topcon instrument had a precision of $\pm 0.01 \mathrm{ft}$ for elevation and $\pm 0.1 \mathrm{ft}$ for horizontal distance, over ranges used in this study. The bathymetric mapping approach using a Topcon instrument was preferred because of the precision of the instrument. Topcon typically was used when the wetland was small and the line of sight was not limited. This approach could not be used at five of the study sites, however, because of deep water or a high density of trees and a short line of sight. The DGPS instrument was used for mapping the horizontal location of bathymetric data points at these sites, but it was less precise than the Topcon instrument. In marshes with no tree cover, the location of data points mapped by DGPS had a precision of \pm 10 - $15 \mathrm{ft}$. In cypress wetlands with a dense tree canopy, interference resulted in a weaker DGPS signal and the precision of the instrument was $\leq 45 \mathrm{ft}$. The depth of water determined using a graduated rope or rod at five of the sites had a precision of $\pm 0.01 \mathrm{ft}$, and the depth of water measured at Duck Pond using a Secchi disk had a precision of $0.1 \mathrm{ft}$.

Efforts were made to collect a large number of bathymetric data points at all sites. Topcon was used to collect about 62 points per acre at GS Marsh, 59 points per acre at S-63 Cypress, 49 points per acre at HRSP Marsh, and 35 points per acre at W-19 Cypress. Bathymetric data also were collected with the Topcon at W-29 Marsh, but because of its large size only 18 points per acre were collected. In two of the other large wetlands (Duck Pond Marsh and S-68 Cypress), DGPS and the depth of water were used to map bathymetry. The density of data points was lower at these sites (about 11 points per acre and 8 points per acre, respectively) not only because of their large size but also because of deep water at the former site, and a high density of trees at the latter site.

Fallen trees, leaning trees, small hummocks of vegetation, and small holes generally were avoided during surveying in an attempt to describe the elevation of the wetland bottom on a large scale. Wetland soils commonly are highly organic at the surface and compressible, compacting during dry periods and expanding when rewetted. These and other characteristics of wetland surfaces affect estimates of stage-area and stage-volume derived by bathymetric mapping, and have their greatest effect on estimates generated from bathymetric data with a low density of data points. In this study, however, we assumed that the contribution of these sources of error were equivalent for each mapping approach. 


\section{Creation of Bathymetric Contour Maps and Calculation of Wetland Area and Stored Water Volume}

A bathymetric data set of horizontal and vertical coordinates was created for each wetland. Each bathymetric data set included the data points collected within the perimeter of the wetland as well as the data points along the wetland perimeter. The software package SURFER was used to draw continuous contour lines by interpolation of the land-surface elevations using the kriging method (Keckler, 1997). Bathymetric contour maps were created at $0.5-\mathrm{ft}$ contour intervals, with the exceptions of Duck Pond Marsh, which was relatively deep (1.0 ft intervals) and GS Marsh, which was relatively shallow (0.2 ft intervals). The contour intervals were chosen so that they were relevant to the scale of the topographic features in each wetland. The volume and area integration tools in SURFER were used to calculate wetland area and stored water volume for given stages (app. 2-11). Estimated area and volume were plotted as a function of stage for each wetland to compare stage and area, and to compare stage and volume.

Wetland bathymetry in this study was mapped using one of two approaches, and depending on wetland size, water depth, and density of trees, each approach generated different densities of bathymetric data points. Before comparing the area and volume estimates for the 10 wetlands, the potential effect of different bathymetric mapping approaches on wetland area and volume estimates was investigated at two wetland sites, GS Marsh and W-29 Marsh. These two wetlands were chosen for the comparison because they have shapes characteristic of the wetlands analyzed in this study: GS Marsh is nearly circular whereas W-29 Marsh has an elongated shape. In addition to the bathymetric maps originally generated at GS Marsh and W-29 Marsh using the Topcon method, two additional bathymetric maps were generated for each of these two wetlands, based on two simpler approaches. The areas and volumes estimated at different stages by the two simpler approaches were compared to the Topcon approach, and results were used to infer the potential magnitude of errors from mapping approaches that use reduced densities of data points.

In the first of the simpler mapping approaches, the number of elevation data points collected with Topcon at the two wetlands was reduced until only three lines (transects) of data points remained at W-29 Marsh and two transects remained at GS Marsh. The density of topographic data points, in turn, was reduced from an average of 18.2 points per acre to 4.6 points per acre at W-29 Marsh, and from 61.9 points per acre to 12.5 points per acre at GS Marsh. The new wetland bathymetry based on transect lines (and the known wetland perimeter) was interpreted using SURFER and the results were compared to the original Topcon mapping results.

In the second of the simpler mapping approaches, it was assumed that one other elevation contour is known in addition to the elevation of the wetland perimeter. This contour traces the outline of the inundated area at some stage intermediate to either full or dry. One elevation contour was selected for GS Marsh and for W-29 Marsh from the suite of contours developed from the Topcon mapping approach. This contour was added to simulate the additional bathymetric contour that could be determined in a wetland by mapping points along the edge of the flooded area with a DGPS unit.

\section{Assessment of Wetland Vegetation}

Vegetation was assessed semiannually in all marsh and cypress wetland sites in May and October 2002, May and October 2003, and May 2004. At each wetland site, a transect line was established from the perimeter to the deepest point in the wetland. Three zones were established along the transect line and were defined as transition, intermediate, or deep based on their elevation relative to the elevation at the wetland perimeter. The transition zone was located 3-6 inches downslope from the elevation of the wetland perimeter (in marshes, 3-6 inches below the base of the palmetto fringe; in cypress wetlands, 3-6 inches downslope from the normal pool elevation). The deep zone was located near a point of lowest elevation (maximum water depth) at each wetland. The intermediate zone was located at an elevation half-way between the deep zone elevation and the transition zone elevation. Elevations used to establish these zones were those surveyed by the SWFWMD.

Three 9-square foot $\left(\mathrm{ft}^{2}\right)$ fixed plots were established sideby-side perpendicular to the transect line in each of the three zones at each wetland. All plants visible within each plot were identified to species level and their percent cover was visually estimated. Water depth in each plot was recorded on each sampling date. An ancillary survey of Pinus elliotii (slash pine) trees also was made in January 2004 at W-29 Marsh because slash pines were present throughout this marsh during the study, but the fixed vegetation plots at W-29 Marsh did not include any tree species. The survey included data on location, water depth, tree diameter at breast height (dbh), and tree health (living/dead) of about 120 slash pine trees growing within the marsh.

Verification of species, when necessary, was provided by the University of South Florida Herbarium in Tampa, Florida. Plant names used in this report follow Wunderlin (1998). Plants are listed in vegetation tables if they provided at least 1 percent cover in at least one plot, and plants are highlighted as abundant if they provided at least 10 percent cover in at least one plot.Vegetation plots established in this study do not encompass all species present in each wetland and, therefore, cannot provide an exhaustive list of plant species present in each wetland. For example, plots in cypress wetlands rarely include tree species. Fixed plots, however, provide a consistent method to assess the vegetation community at known elevations, and to monitor changes in vegetation over time.

Wetland plants were assigned a status (app. 12) based either on the Florida vegetative index (Florida Department of Environmental Protection, 2004) or the Atlas of Florida Vascular 
Plants (Wunderlin and Hansen, 2004). Any plant not specifically listed in the index is considered an upland plant with the exception of vines and aquatic plants. Aquatic plants are those, including the roots, that typically float on water or require water for their entire structural support, or they desiccate outside of water (Florida Department of State, 1994). The indicator categories are: Obligate wetland species (OBL); Facultative wetland species (FACW); and Facultative species (FAC). According to Federal guidelines (Reed, 1988), an OBL species is present in wetlands greater than 99 percent of the time; a FACW species is present in wetlands 67-99 percent of the time; and a FAC species is present in wetlands 34-66 percent of the time. Although both OBL and FACW species are widely recognized as useful indicators of wetlands, FAC species can be dominant plants in uplands as well as in wetlands, and therefore, are not considered to be reliable indicators of wetlands.

\section{Bathymetry of Marsh and Cypress Wetlands}

The surface area of the five marsh wetlands ranged from 1.6 - 7.4 acres, with an average size of 4.6 acres (table 1). The surface area of the five cypress wetlands ranged from 1.3-8.8 acres with an average of 3.9 acres. Generally, the smaller wetlands are shallower than the larger wetlands. For example, GS Marsh has an area of 1.6 acres and a maximum depth of $1.07 \mathrm{ft}$ whereas W-03 Marsh has an area of 7.4 acres and a maximum depth of $5.44 \mathrm{ft}$. W-05 Cypress is an exception, however, because it has the largest surface area ( 8.8 acres) but an intermediate maximum depth of $2.11 \mathrm{ft}$. The relatively shallow depth at W-05 Cypress could be due in part to the thick layer of flocculent sediment that has accumulated on the floor of the wetland and filled in the deeper parts of the wetland basin.

The bathymetric surveys indicate that 8 of the 10 wetlands in this study are shallow with a maximum depth of $3 \mathrm{ft}$ or less (figs. 2A-11A). Two of the wetlands are deeper than $3 \mathrm{ft}$; Duck Pond Marsh has a maximum depth of $8.13 \mathrm{ft}$ and W-03 Marsh has a maximum depth of $5.44 \mathrm{ft}$. At several of the sites, the maximum depth was in the bottom of a small isolated depression. An extreme example is at W-03 Marsh (fig. 8A), where the maximum depth was in a depression 3-ft deep with a surface area of only $150 \mathrm{ft}^{2}$. To avoid distorting the comparison of wetland depths caused by small but deep pits in a few wetlands, mean depth (total volume divided by total area) was used to compare wetland depths. The mean depth of the four marshes (excluding Duck Pond Marsh) ranged from 0.62-1.89 ft, with an average depth of $1.16 \mathrm{ft}$ (table 1). Duck Pond Marsh had the greatest mean depth of any wetland site $(3.20 \mathrm{ft})$ and is not representative of the other marshes in this study. Mean depths of the cypress wetlands range from 0.46 to $1.08 \mathrm{ft}$, with an average depth of $0.69 \mathrm{ft}$. Data from the 10 wetlands in this study are not sufficient to determine whether these ranges of mean depths are representative of all the wetlands in the NTB area; however, it is noteworthy that the average mean depth of the four marshes (excluding Duck Pond Marsh) is nearly double that of the five cypress wetlands.
Wetland-surface areas estimated in this study using DGPS were compared to wetland areas summarized in the National Wetlands Inventory (NWI) for 9 of the 10 study wetlands (app. 13). NWI maps produced by the U.S. Fish and Wildlife Service (FWS) use aerial photointerpretation to describe the location and extent of wetlands throughout the United States (U.S. Fish and Wildlife Service, 2004). NWI maps are used to delineate wetland boundaries, classify wetlands by type, and provide physical data including surface area. The NWI maps do not show all wetlands because maps are derived from aerial photointerpretation with varying limitations resulting from scale, wetland size, photo quality, inventory techniques, and other factors. These same limitations can cause wetland boundaries shown on the NWI maps to deviate from boundaries derived from ground surveys.

Wetland-surface areas determined by the field methods used in this study were similar to the areas determined for these same wetlands by NWI photogrammetric interpretation of 7.5minute quadrangles, although some notable differences did occur. The area determined in this study for W-19 Cypress (2.1 acres) was not directly comparable to a NWI area because W-19 Cypress was not classified by the NWI as a small, isolated wetland, but instead as a part of a much larger wetland (20.9 acres). As a result, $\mathrm{W}-19$ Cypress is not included in the comparison in appendix 13. If the surface-area estimates for the nine other wetlands are summed for each method, the total wetland area estimates are similar (USGS $=40.5$ acres; NWI $=39.6$ acres). Although the summed areas agreed closely, four of the marsh wetland area estimates differed by 25 to 35 percent. Surfacearea estimates for the five cypress wetlands and the remaining marsh wetland differed by 8 percent or less (app. 13). The FWS noted that wetland identification using NWI methods was particularly difficult when photography was captured during a dry year, whereas USGS methods used in this study are independent of short-term annual variations in rainfall and wetland water level (U.S. Fish and Wildlife Service, 2004).

\section{Stage-Area-Volume Relations for Marsh and Cypress Wetlands}

Stage typically is the most important if not the only hydrologic property monitored in wetlands. Hydrologic interpretations based on wetland stage require that the location and the elevation of the staff gage are accurately known. The locations of all staff gages found inside the 10 wetlands in this study are listed in appendix 1 . The locations of the staff gages also are plotted on the bathymetric contour maps (figs. 2A-11A) to show the depth of the wetland at the staff gage locations. 


\section{Duck Pond Marsh}
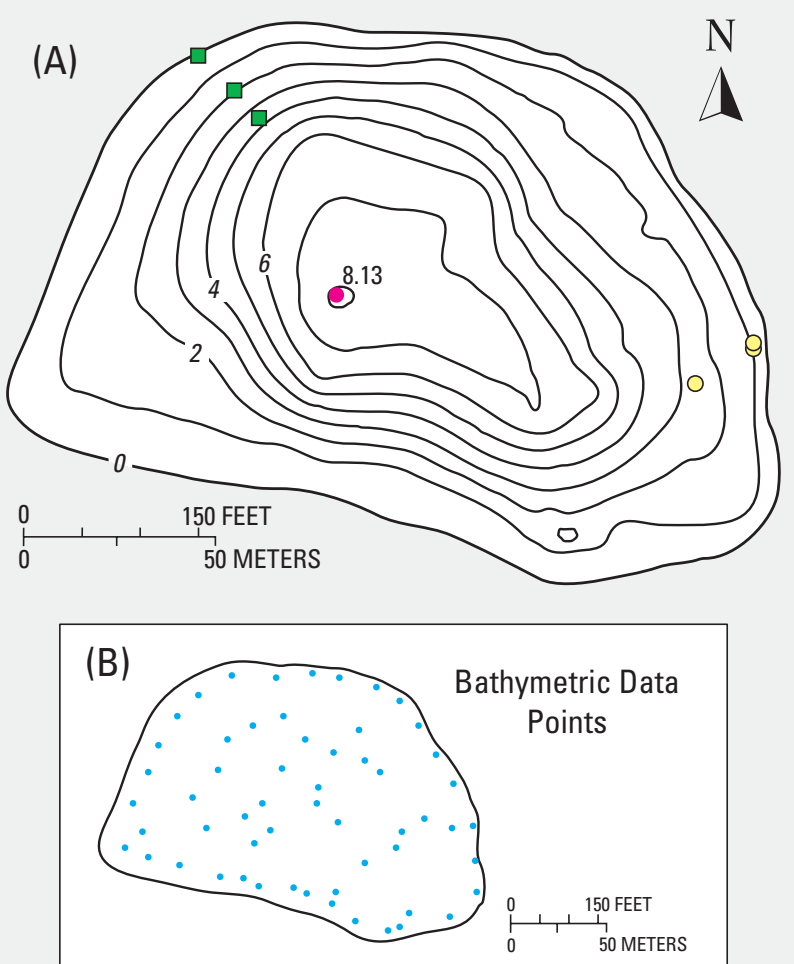

\section{EXPLANATION}

BATHYMETRIC CONTOURS - Depth in feet below wetland perimeter elevation of 70.48 feet above NGVD of 1929. Interval is 1 foot.

$\square \quad$ VEGETATION PLOTS

- DEEPEST POINT - showing elevation in feet below elevation of wetland perimeter

O STAFF LOCATION

- BATHYMETRIC POINT - Location where bathymetric measurement made.

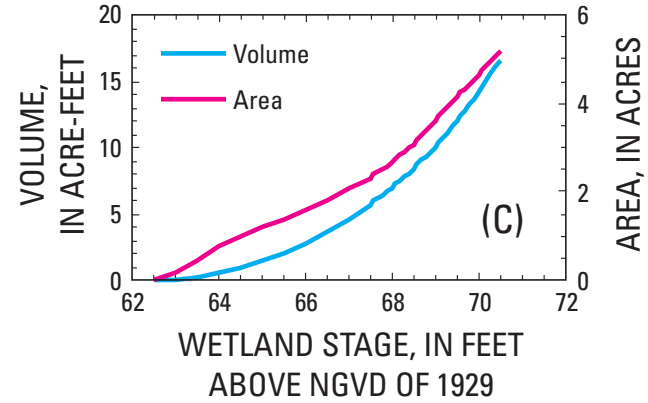

Figure 2. (A) Wetland bathymetric contours, (B) density of bathymetric data points, and (C) stage-volume and stage-area curves for Duck Pond Marsh.

\section{Green Swamp Cypress}

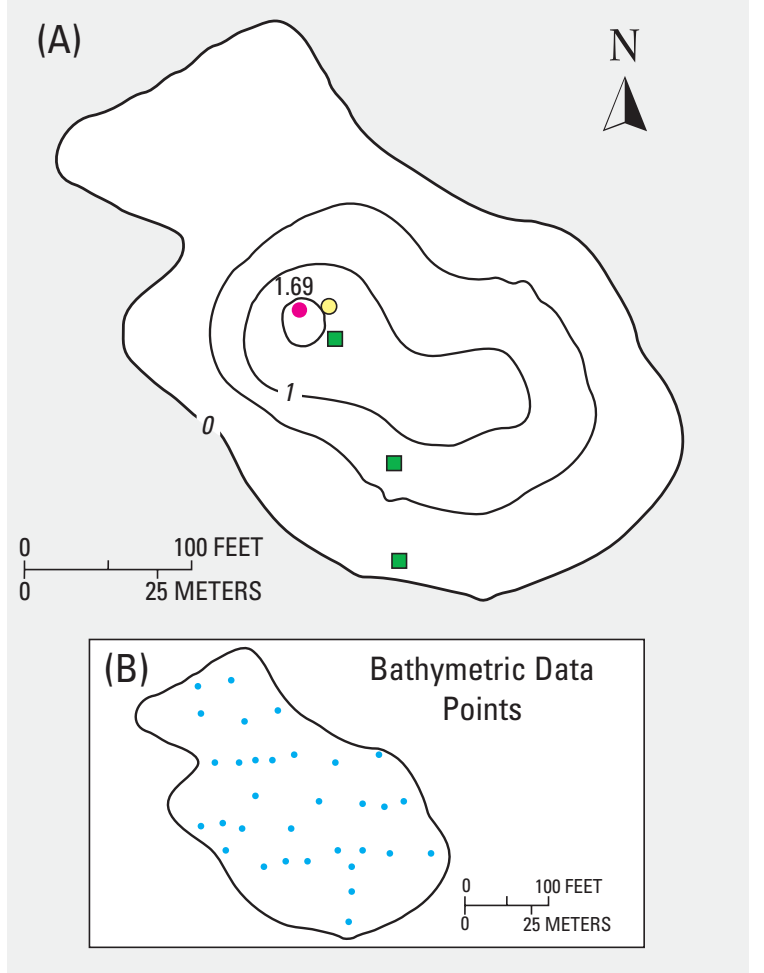

\section{EXPLANATION}

BATHYMETRIC CONTOURS - Depth in feet below wetland perimeter elevation of 98.56 feet above NGVD of 1929. Interval is 0.5 foot.

— VEGETATION PLOTS

- DEEPEST POINT - showing elevation in feet below elevation of wetland perimeter

○ STAFF LOCATION

- $\quad$ BATHYMETRIC POINT - Location where bathymetric measurement made.

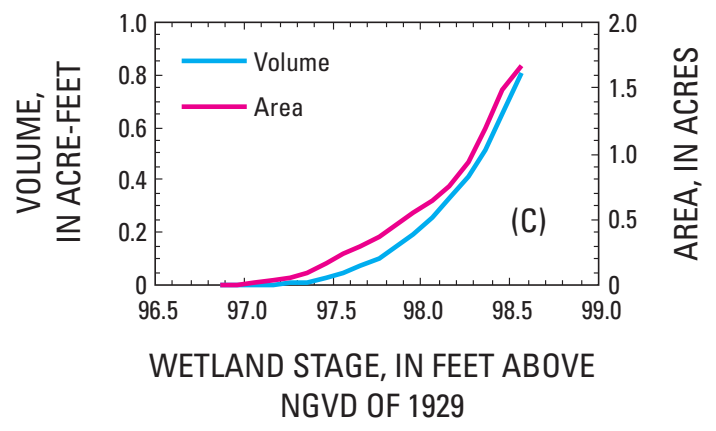

Figure 3. (A) Wetland bathymetric contours, (B) density of bathymetric data points, and (C) stage-volume and stage-area curves for Green Swamp Cypress. 


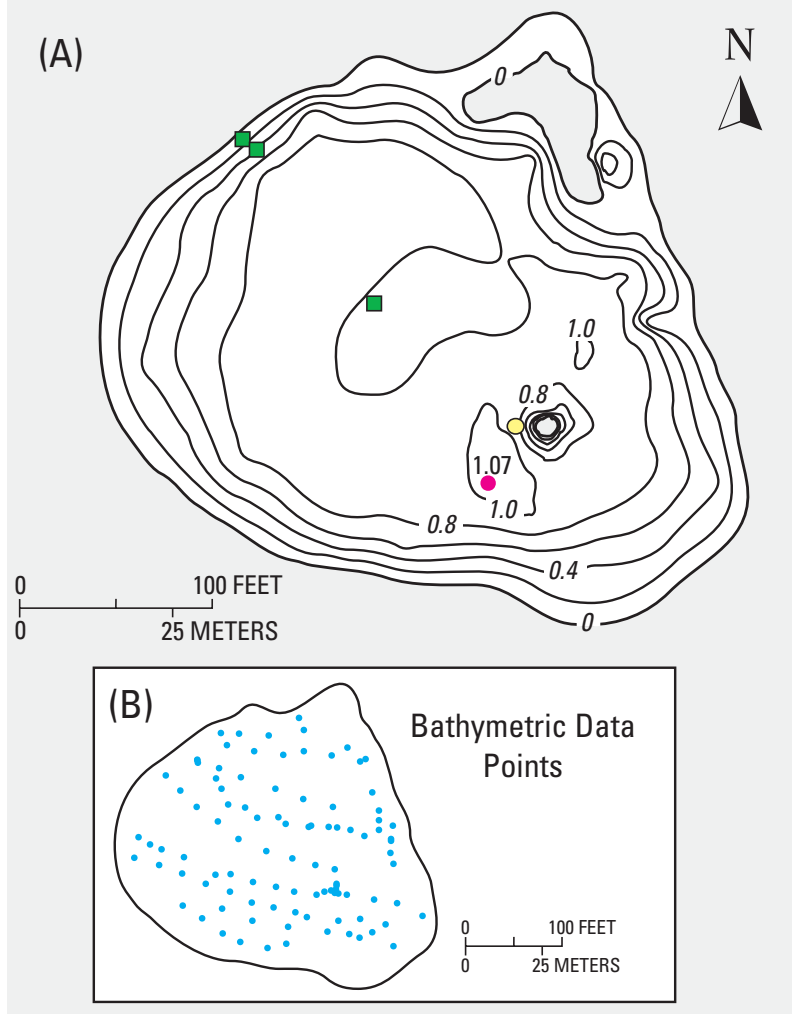

\section{EXPLANATION}

BATHYMETRIC CONTOURS - Depth in feet below wetland perimeter elevation of 93.30 feet above NGVD of 1929. Interval is 0.2 foot.

VEGETATION PLOTS

- DEEPEST POINT - showing elevation in feet below elevation of wetland perimeter

○ STAFF LOCATION

- BATHYMETRIC POINT - Location where bathymetric measurement made.

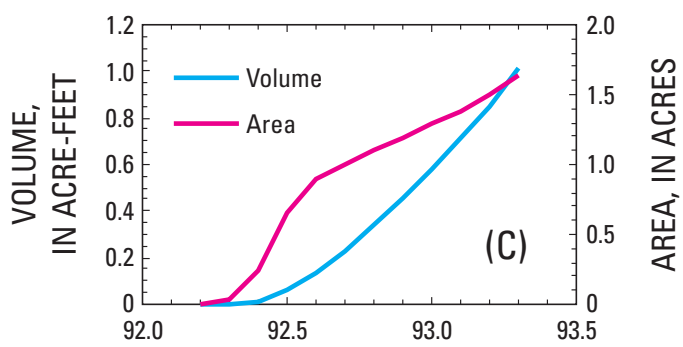

WETLAND STAGE, IN FEET ABOVE NGVD OF 1929

Figure 4. (A) Wetland bathymetric contours, (B) density of bathymetric data points, and (C) stage-volume and stage-area curves for Green Swamp Marsh.

\section{Hillsborough River State Park Marsh}

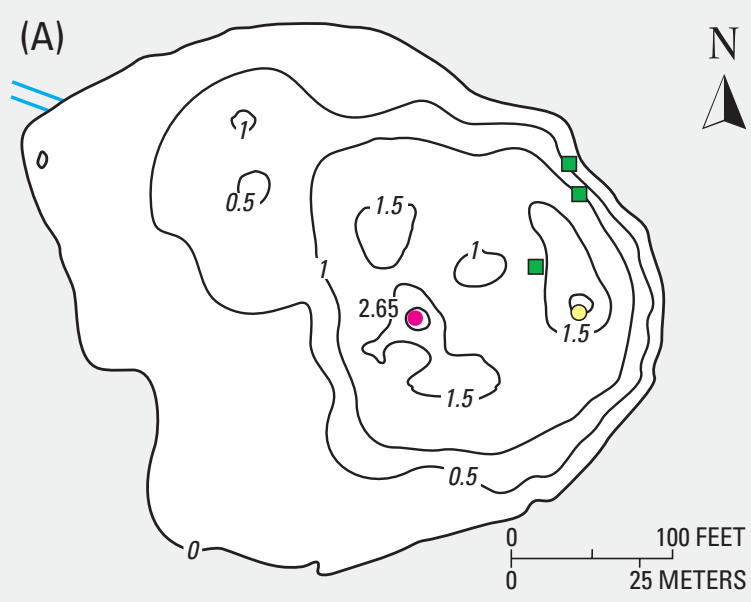

\section{EXPLANATION}

BATHYMETRIC CONTOURS - Depth in feet below wetland perimeter elevation of 46.35 feet above NGVD of 1929. Interval is 0.5 foot.

ロ VEGETATION PLOTS

- DEEPEST POINT - showing elevation in feet below elevation of wetland perimeter

O STAFF LOCATION

- BATHYMETRIC POINT - Location where bathymetric measurement made.

$=$ DITCH - with outflow elevation higher than elevation of wetland perimeter.

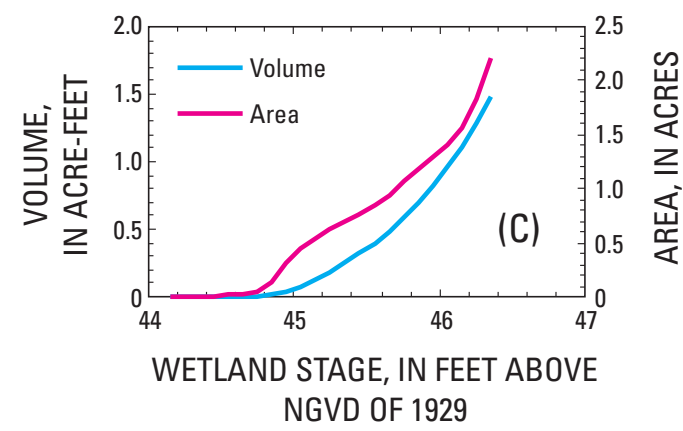

Figure 5. (A) Wetland bathymetric contours, $(B)$ density of bathymetric data points, and (C) stage-volume and stage-area curves for Hillsborough River State Park Marsh. 


\section{S-63 Cypress}

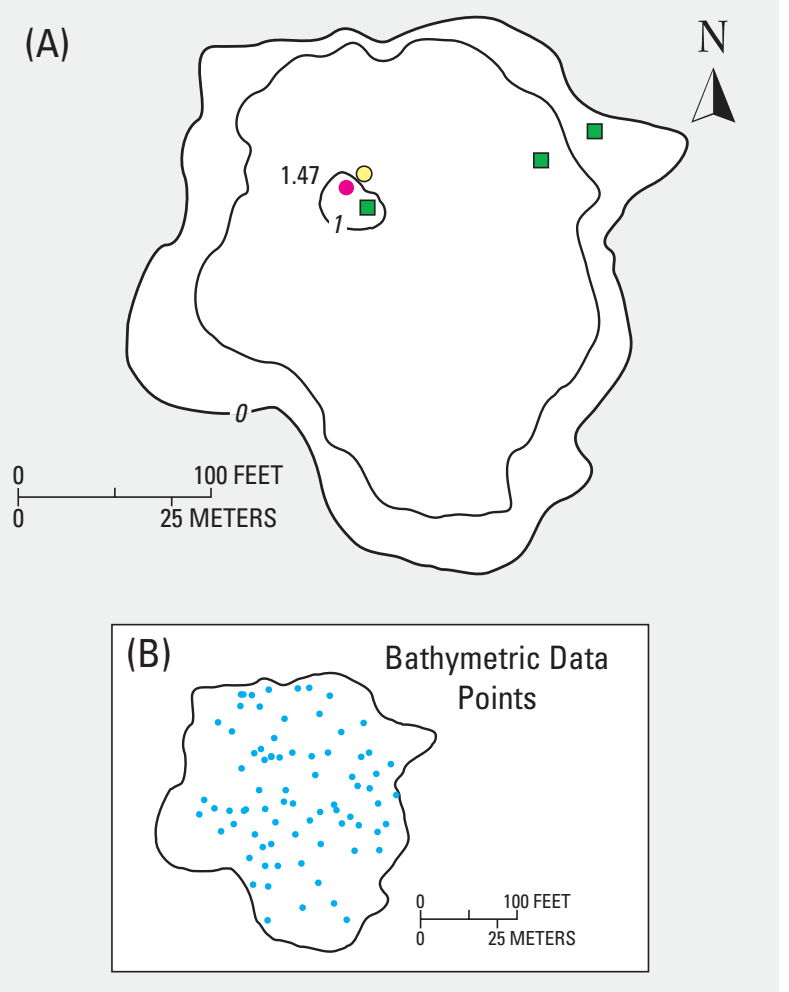

\section{EXPLANATION}

BATHYMETRIC CONTOURS - Depth in feet below wetland perimeter elevation of 42.32 feet above NGVD of 1929. Interval is 0.5 foot.

VEGETATION PLOTS

- DEEPEST POINT - showing elevation in feet below elevation of wetland perimeter

O STAFF LOCATION

- BATHYMETRIC POINT - Location where bathymetric measurement made.

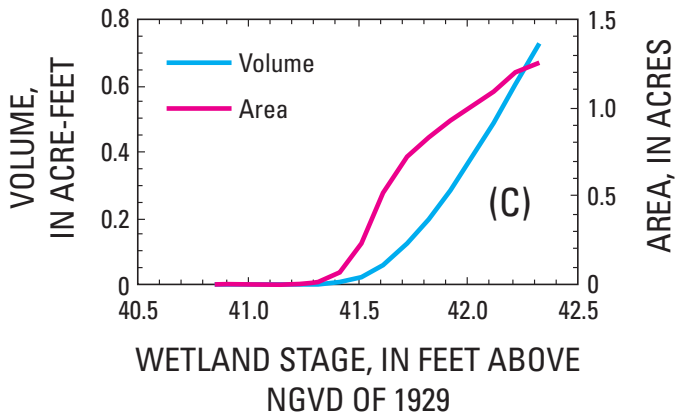

Figure 6. (A) Wetland bathymetric contours, (B) density of bathymetric data points, and (C) stage-volume and stage-area curves for S-63 Cypress.

\section{S-68 Cypress}

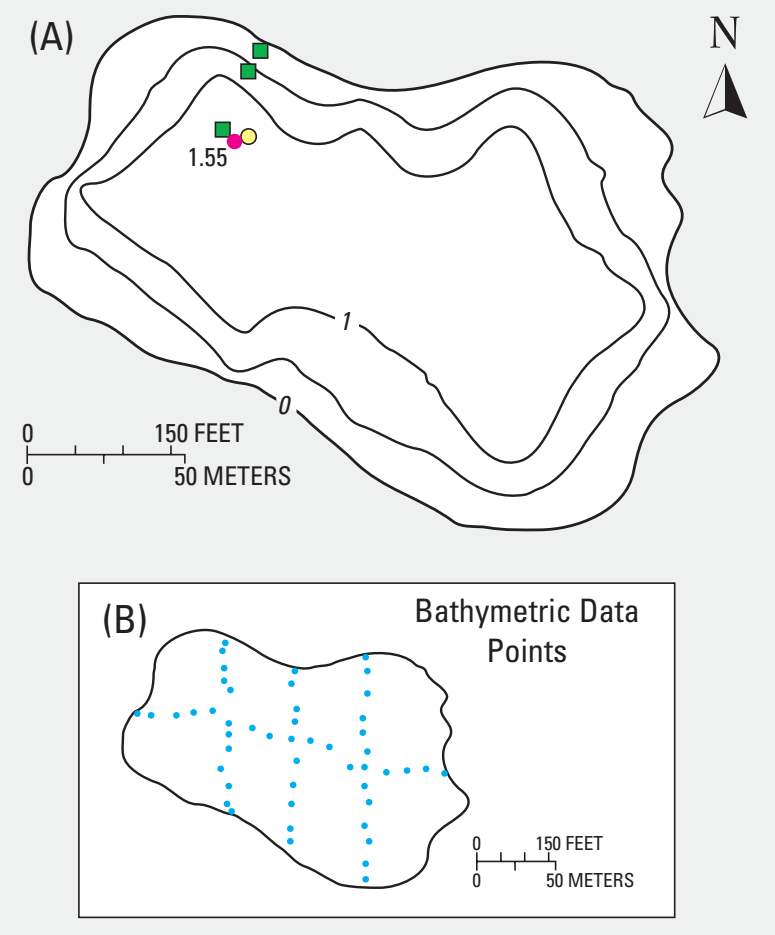

\section{EXPLANATION}

BATHYMETRIC CONTOURS - Depth in feet below wetland perimeter elevation of 43.66 feet above NGVD of 1929 Interval is 0.5 foot

$\square \quad$ VEGETATION PLOTS

- DEEPEST POINT - showing elevation in feet below elevation of wetland perimeter

O STAFF LOCATION

- BATHYMETRIC POINT - Location where bathymetric measurement made.

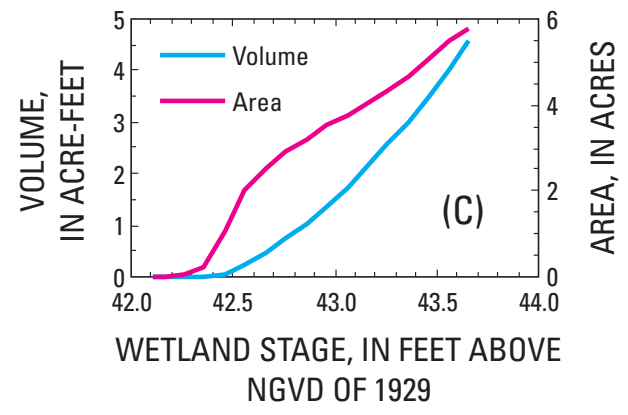

Figure 7. (A) Wetland bathymetric contours, (B) density of bathymetric data points, and (C) stage-volume and stage-area curves for S-68 Cypress. 


\section{W-03 Marsh}

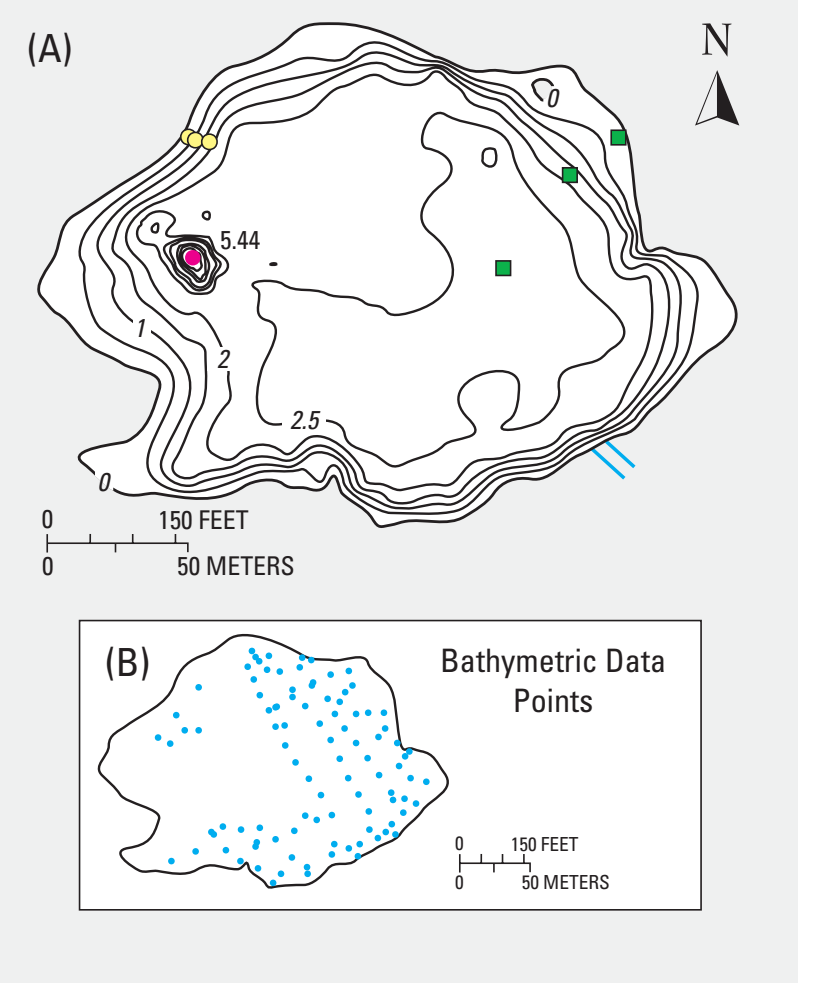

\section{EXPLANATION}

BATHYMETRIC CONTOURS - Depth in feet below wetland perimeter elevation of 72.44 feet above NGVD of 1929. Interval is 0.5 foot

VEGETATION PLOTS

- DEEPEST POINT - showing elevation in feet below elevation of wetland perimeter

O STAFF LOCATION

- $\quad$ BATHYMETRIC POINT - Location where bathymetric measurement made

DITCH - with outflow elevation higher than elevation of wetland perimeter.

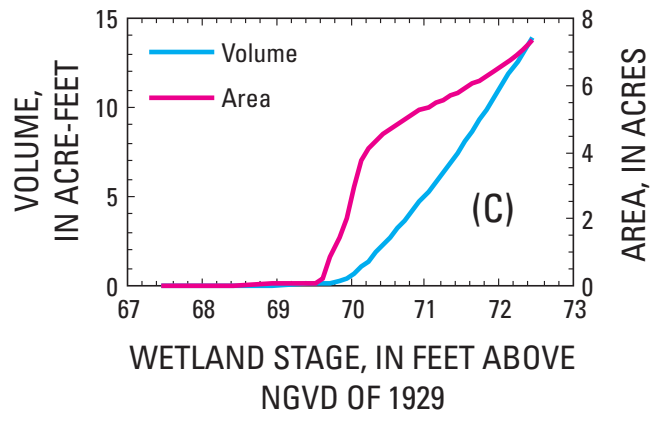

Figure 8. (A) Wetland bathymetric contours, $(B)$ density of bathymetric data points, and (C) stage-volume and stage-area curves for W-03 Marsh.

\section{W-05 Cypress}

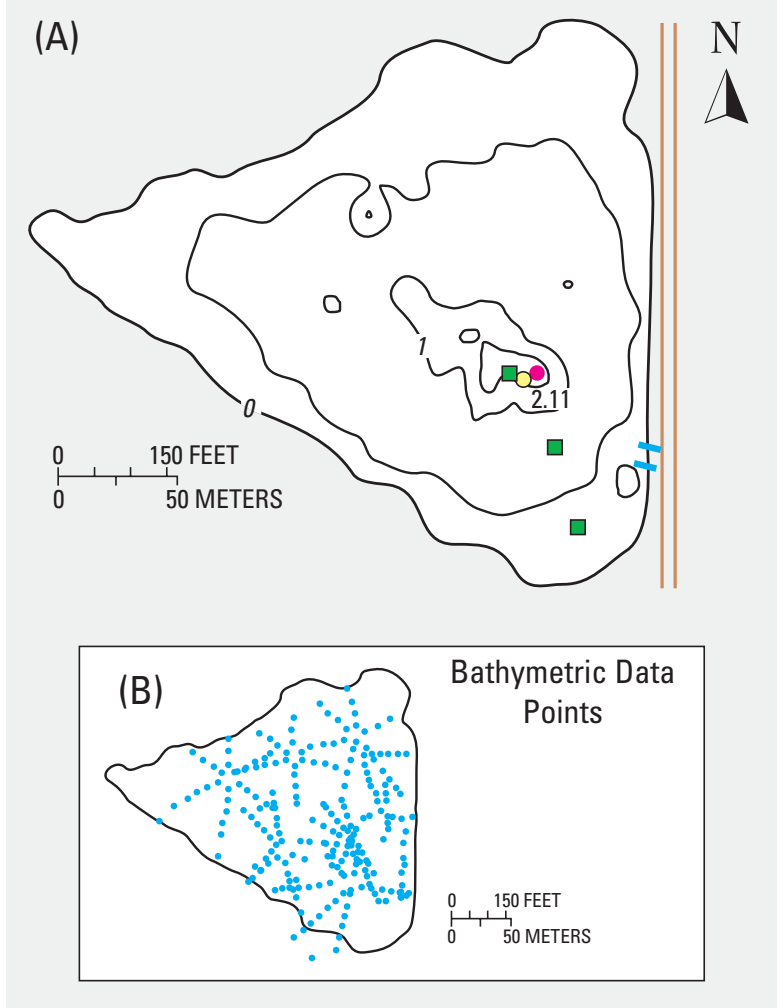

\section{EXPLANATION}

- BATHYMETRIC CONTOURS - Depth in feet below wetland perimeter elevation of 71.47 feet above NGVD of 1929. Interval is 0.5 foot

VEGETATION PLOTS

- DEEPEST POINT - showing elevation in feet below elevation of wetland perimeter

O STAFF LOCATION

- BATHYMETRIC POINT - Location where bathymetric measurement made

= DIRT ROADWAY - Elevation higher than wetland perimeter elevation

- WETLAND OUTFLOW - to roadside ditch at approximate elevation of 71.0 feet above NGVD of 1929

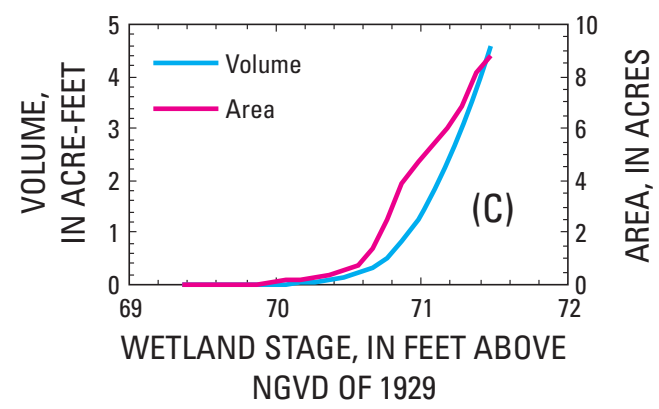

Figure 9. (A) Wetland bathymetric contours, $(B)$ density of bathymetric data points, and (C) stage-volume and stage-area curves for W-05 Cypress. 


\section{W-19 Cypress}

(A)
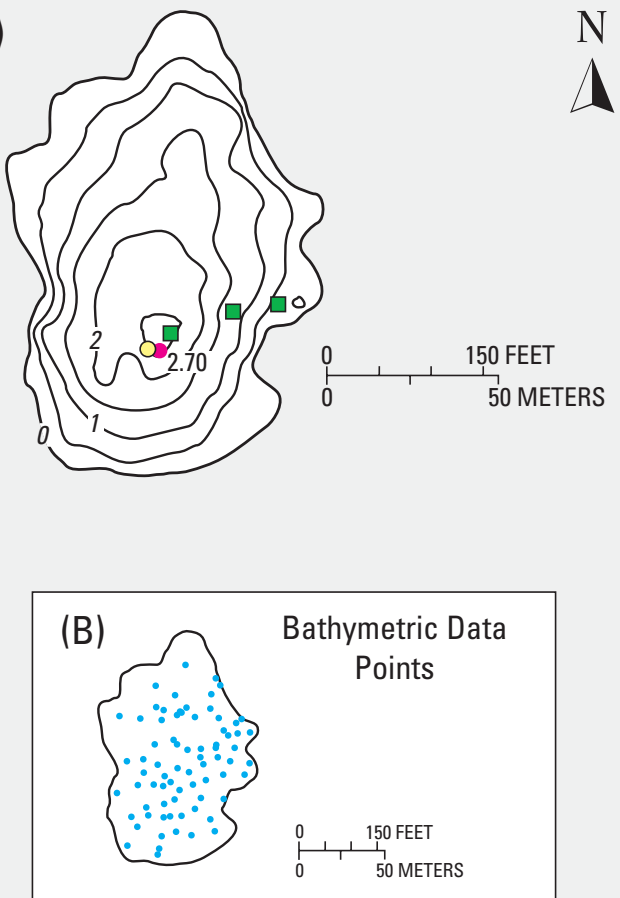

EXPLANATION

BATHYMETRIC CONTOURS - Depth in feet below wetland perimeter elevation of 63.23 feet above NGVD of 1929. Interval is 0.5 foot

VEGETATION PLOTS

- DEEPEST POINT - showing elevation in feet below elevation of wetland perimeter

O STAFF LOCATION

- $\quad$ BATHYMETRIC POINT - Location where bathymetric measurement made

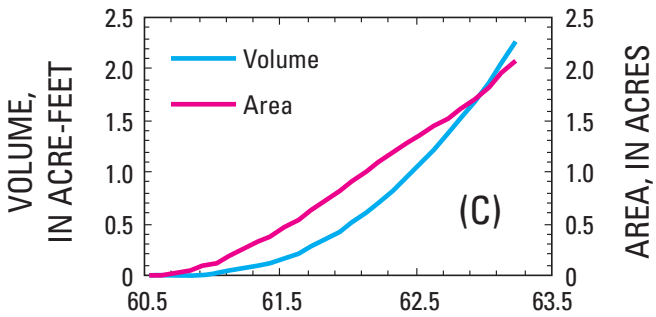

WETLAND STAGE, IN FEET ABOVE

NGVD OF 1929

Figure 10. (A) Wetland bathymetric contours, (B) density of bathymetric data points, and (C) stage-volume and stage-area curves for W-19 Cypress.

W-29 Marsh

(A)
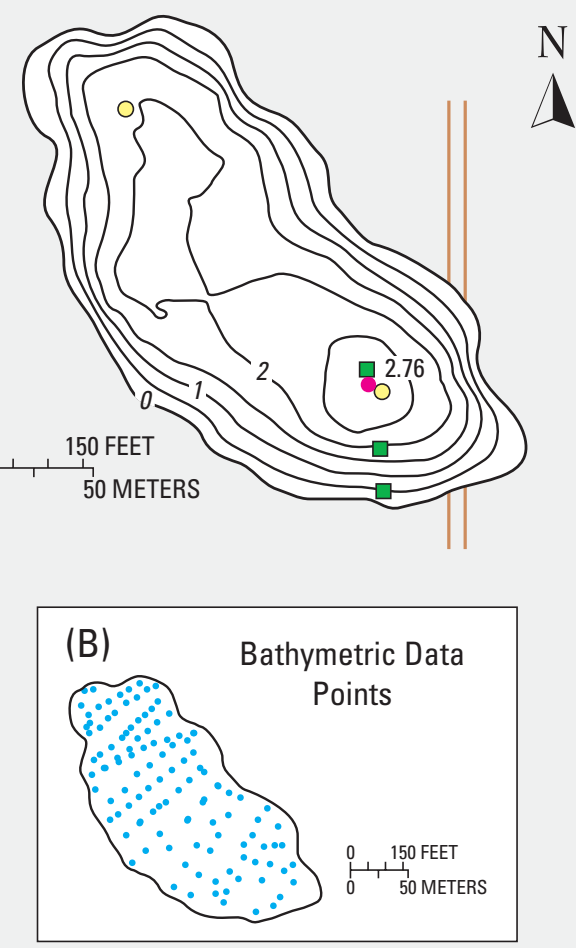

\section{EXPLANATION}

BATHYMETRIC CONTOURS - Depth in feet below wetland perimeter elevation of 69.92 feet above NGVD of 1929. Interval is 0.5 foot

VEGETATION PLOTS

- DEEPEST POINT - showing elevation in feet below elevation of wetland perimeter

O STAFF LOCATION

- BATHYMETRIC POINT - Location where bathymetric measurement made

- DIRT ROADWAY - Wetland outflow at an elevation higher than elevation of wetland perimeter

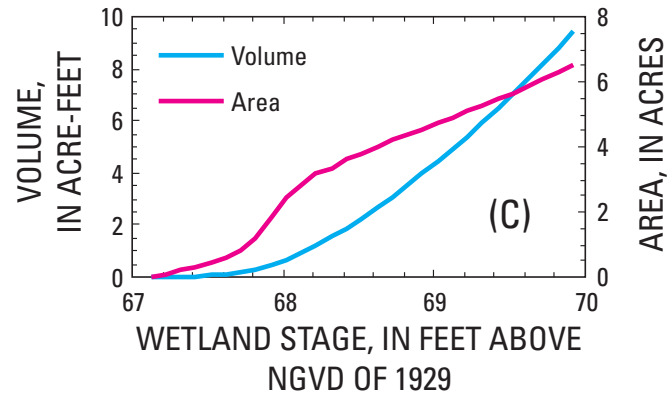

Figure 11. (A) Wetland bathymetric contours, (B) density of bathymetric data points, and (C) stage-volume and stage-area curves for W-29 Marsh. 
Ideally, a staff gage would be located at the deepest point in the deepest part of a radially symmetrical basin, in order to accurately describe the wetland as dry when the staff gage is dry. Many wetlands, however, are not radially symmetrical even though they commonly originate as subsidence features, and actual staff gage locations are not always ideal. Without bathymetric data, improperly placed staff gages can go unrecognized. For example, at W-29 Marsh (fig. 11A) the bathymetric map indicates that the wetland has two distinct basins. The original staff gage was not located at the deepest point in the wetland, and the longest historical record of stage at W-29 Marsh was collected from a staff gage located in the shallower (or higher) of the two basins. The land-surface elevation at this original staff gage is $68.00 \mathrm{ft}$ above NGVD of 1929. For this study a second staff gage and a continuous stage recorder were installed in the lower (or deeper) basin at a land-surface elevation of $67.30 \mathrm{ft}$ above NGVD of 1929. The elevation of the lowest point measured during collection of bathymetric data at W-29 Marsh was $67.20 \mathrm{ft}$ above NGVD of 1929. When the original staff gage at the higher elevation was used to determine stage, the wetland was commonly described as dry ( 0 percent inundation), when in reality the area inundated at W-29 Marsh could have ranged from 0 to 2.4 acres (app. 11).

Conversely, a bias results if the staff gage is located in an uncharacteristically deep hole in the lowest part of a wetland. Small deep holes are common in wetlands. They may be subsidence features or they may be dug by feral hogs or other animals that use wetlands as feeding areas, watering holes, or breeding grounds. The staff gage is not located in the small, deep hole at W-03 Marsh; however if it was, a water depth of $2 \mathrm{ft}$ would inundate less than 1 percent of the wetland-surface area. Although it is not possible to retroactively optimize the location of staff gages that have been used to collect historical data, a thorough knowledge of bathymetry allows for a much more accurate interpretation of available stage data.

Bathymetric data were used to summarize the relations between stage and area, and stage and volume for each of the wetlands in this study (figs. 2C-11C). The plots of stage-areavolume and the bathymetric maps indicate that the inundated surface area and stored water volume can change substantially over a relatively small increment of stage. In general, stage-area curves show the largest incremental changes in wetland area at lower stages. This pattern occurs because the relatively flat bottom of most of the wetlands causes a large increase in wetted area with a small increase in wetland stage. In contrast, the stage-volume curves show a slow increase in volume at lower stages because the increased area does not contribute to much increase in volume. W-03 Marsh is an exception to this pattern because it has one small depression about 3-ft deep in an otherwise flat wetland bottom. Thus, at low stages, a small increase in surface area results from a relatively large increase in water volume at W-03 Marsh (fig. 8C).

At higher wetland stages, as the flooded area approaches the perimeter (near 100 percent inundation), a large increase in wetland volume is required to produce a relatively small increase in surface area. For example, adding 3.0 acre-feet (acre-ft) of water to W-29 Marsh when it is dry (assuming no leakage losses or evaporation) would inundate 4.1 acres, or 63 percent of the total surface area (app. 11). An additional 3.0 acre-ft of water would inundate only 1.2 acres more, or 18 percent of the total surface area.

Hayashi and van der Kamp (2000) developed power functions to describe wetland area and stage for small wetlands in isolated and smoothly sloped depressions in the prairie pothole region of North America. This approach failed, however, when applied to the wetlands in this study (data not shown), because most of the 10 wetlands are not radially symmetrical, and they lack regularly sloping sides and a parabolic shape. Instead, several of the wetlands in this study have irregular shapes, and wetland bottoms have distinct breaks in slope from a relatively flat central area to steep sloped edges. Thus, the resulting stage-area curves for the 10 study wetlands had an S-shaped appearance so that wetland area could not be accurately represented over the entire range in stage by power functions or higher-order polynomials.

Ditches into wetlands or roadways intersecting the perimeter of wetlands can change the stage-area-volume relations by lowering the stage at which outflow begins to occur. For example at W-05 Cypress (fig. 9A), a roadway and the ditches flanking the roadway intersect the wetland perimeter causing outflow at an elevation that is lower than the palmetto fringe elevation of $71.47 \mathrm{ft}$ above NGVD of 1929. When the stage reaches $71.0 \mathrm{ft}$ above NGVD of 1929 at W-05 Cypress, outflow to a ditch adjacent to the road occurs. At a stage of $71.3 \mathrm{ft}$ above NGVD of 1929, outflow from the ditch flows south along the road and discharges into a nearby wetland. The "functioning perimeter" at W-05 Cypress likely occurs at an elevation between 71.0 and $71.3 \mathrm{ft}$ above NGVD of 1929, corresponding to an effective inundated area of between 4.9 and 7.2 acres, respectively. It is unlikely that the inundated area of $\mathrm{W}-05$ Cypress reaches the entire 8.8 acres encompassed by the palmetto fringe. Although HRSP Marsh (fig. 5A) and W-03 Marsh (fig. 8A) have outflow ditches, and W-29 Marsh (fig. 11A) has an intersecting roadway, the elevation of these ditches and the roadway are at or above the perimeter elevation, and do not reduce the effective total wetland area at these sites. Although areas of naturally occurring outflow were identified during the study (see figs. 2A-11A), for the purposes of this report stage-area and stagevolume curves assumed no outflow or inflow below the palmetto fringe. The practical use of these curves for the estimation of water budgets, however, would necessitate consideration of any such inflows or outflows.

\section{Potential Effects of Bathymetric Mapping Approach on Stage-Area and Stage-Volume Relations}

The error introduced by creating bathymetric maps from a lower density of data points was estimated by comparing the original stage-area and stage-volume curves for W-29 Marsh and GS Marsh to those created from the two reduced-density 
data sets. The maps created from a low density of data points lost information about the non-linearity of the basin topography. Fewer data points resulted in a more linear interpolation of the elevation between data points than actually existed. The resulting bathymetric maps generated from a lower density of data points can look convincing, but a comparison to maps created from a high density of data points collected at the same site clearly shows the differences (figs. 12A-C, 13A-C).
At W-29 Marsh, the data set using transect data alone provided a low density of bathymetric points in the area between the two circular basins of the marsh (fig. 12). This is the area of the wetland where the bottom is relatively flat. Within this middle range of stage (67.50-69.00 ft above NGVD of 1929) there is a large increase in inundated area associated with a small change in stage. Linear interpolation of the transect data alone tended to decrease the estimate of flooded area at intermediate water levels.

\section{W-29 Marsh}

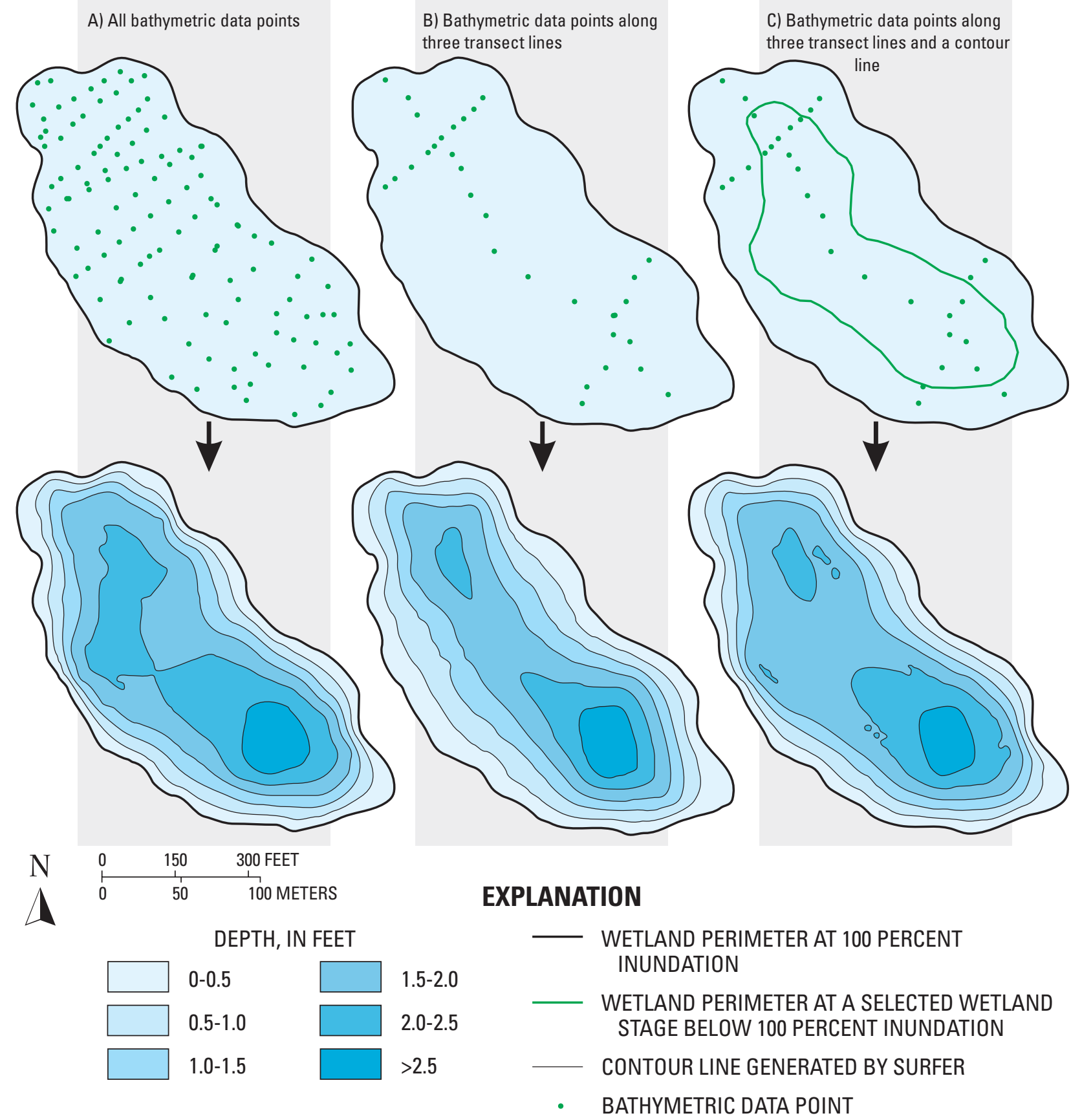

Figure 12. Contour lines developed for W-29 Marsh from (A) all bathymetric data points, $(B)$ a subset of bathymetric data points along three transect lines, and $(C)$ a subset of bathymetric data points along three transect lines and a contour line. 
For both W-29 Marsh and GS Marsh, transect data alone predicted substantially less flooded area at most values of stage. For example, at W-29 Marsh, the estimated flooded area at a stage of $68.02 \mathrm{ft}$ was 1.22 acres (fig. 14A) based on the transect data alone, or about 49 percent less than the 2.41 acres of flooded area predicted at the same stage by using the complete data set. At GS Marsh, the estimated flooded area at a stage of $92.60 \mathrm{ft}$ was 0.54 acres (fig. 15A) based on the transect data alone, or about 40 percent less than the 0.90 acres of flooded area predicted using the complete data set. Flooded area was slightly overpredicted by the transect approach at GS Marsh at higher stage because there is an area inside the wetland perimeter with an elevation higher than the palmetto fringe. This area was not described accurately by the transect data, causing an upward shift in the stage-area curve.

\section{Green Swamp Marsh}

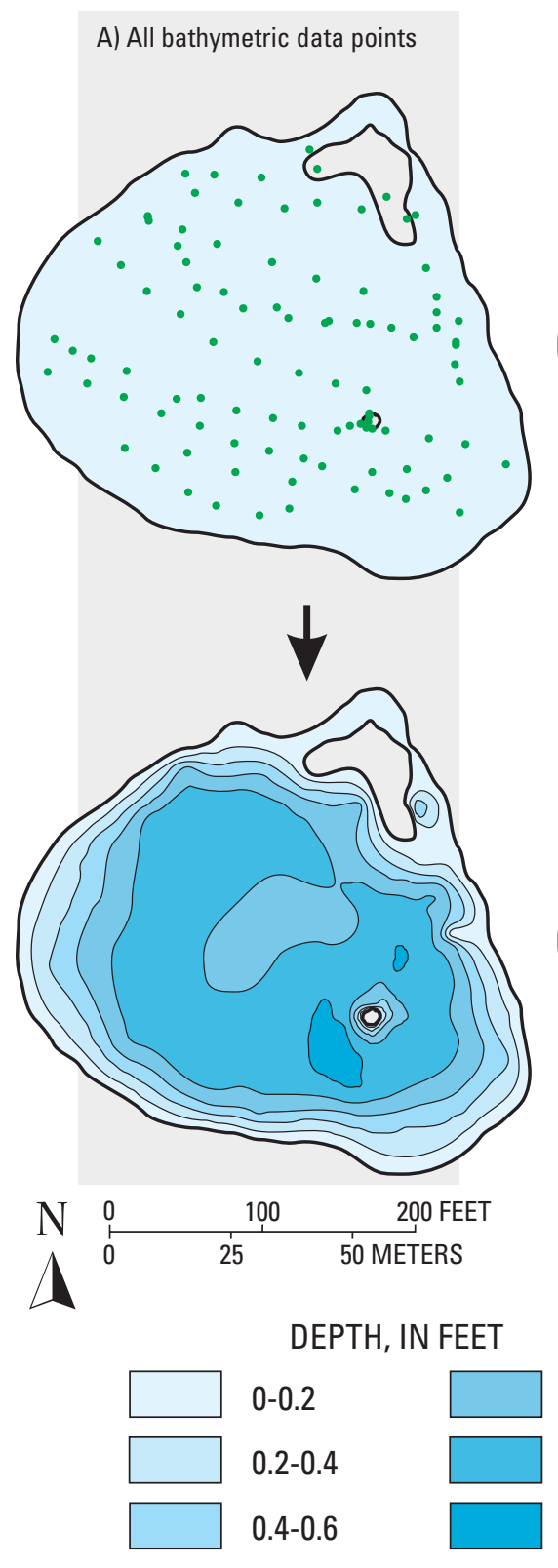

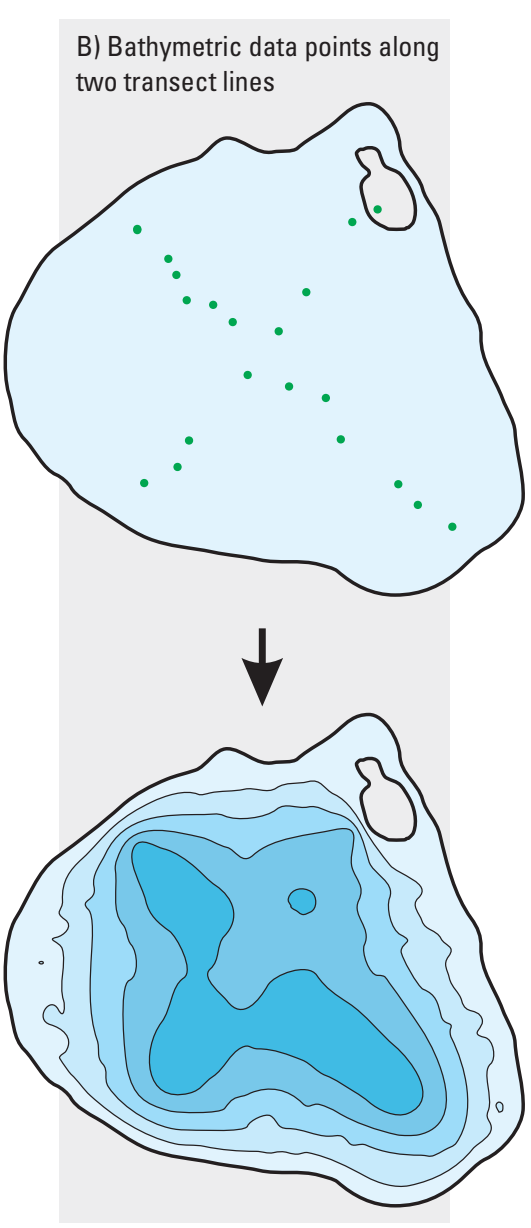

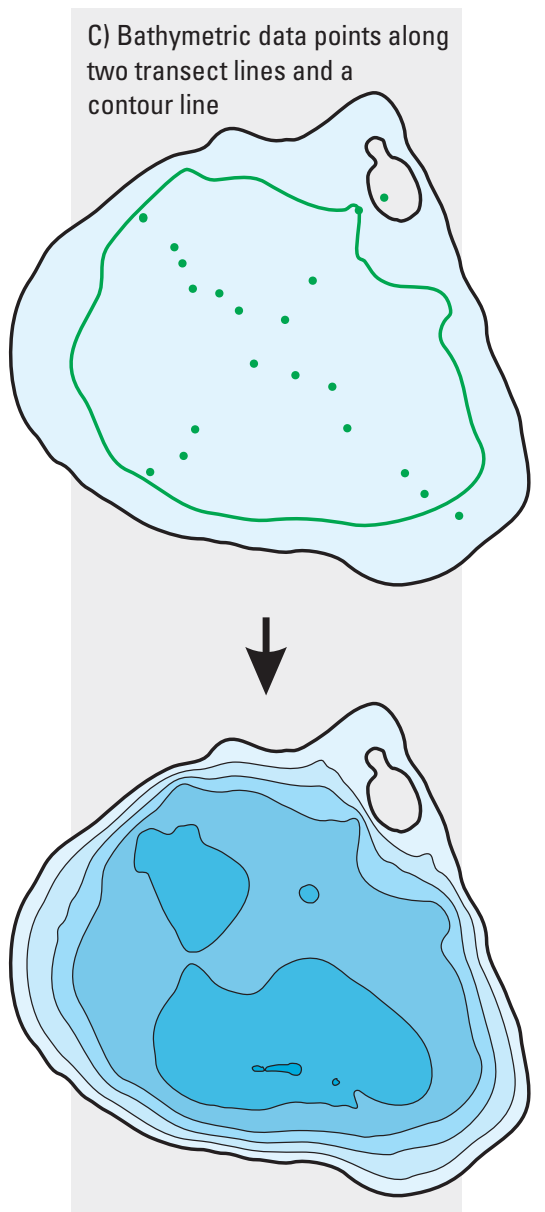

\section{EXPLANATION}

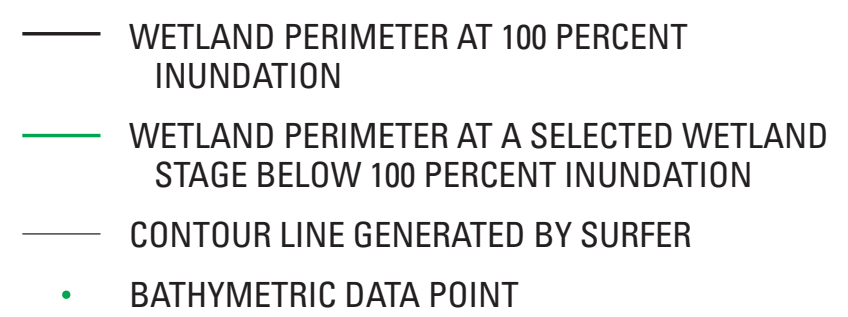

Figure 13. Contour lines developed for Green Swamp Marsh from (A) all bathymetric data points, $(B)$ a subset of bathymetric data points along two transect lines, and $(C)$ a subset of bathymetric data points along two transect lines and a contour line. 

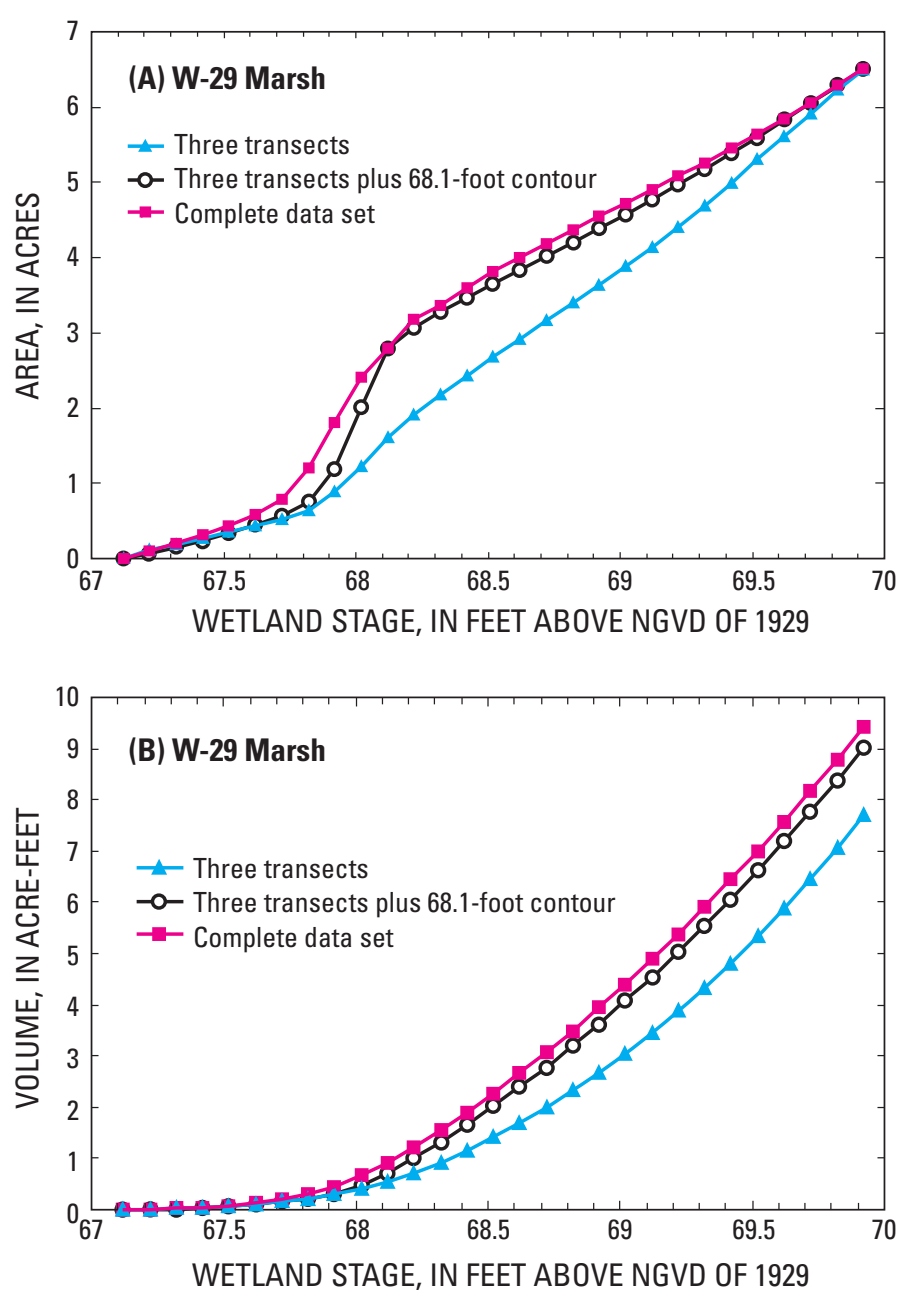

Figure 14. Effects of a reduced density of bathymetric data points at W-29 Marsh on (A) stage-area and (B) stage-volume relations.

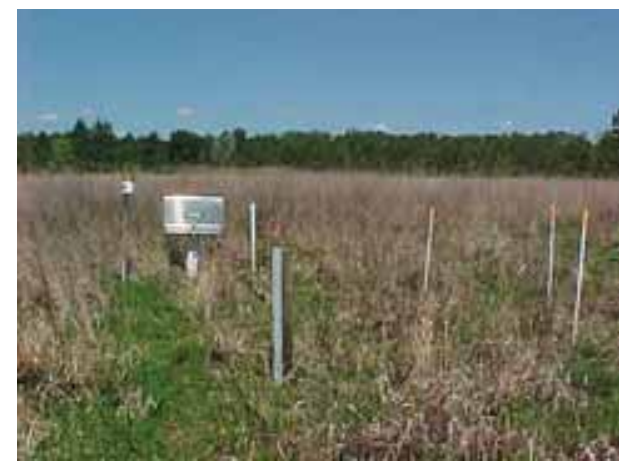

The center of W-29 Marsh supports blue maidencane, dog fennel, and broomsedge bluestem during a prolonged period of low water levels.
The percent error in the flooded-area estimates made using transect data alone increased as the flooded area became smaller at both wetlands, particularly at GS Marsh. For example, when the flooded area at GS Marsh was 0.25 acres, the transect approach (fig. 13B) estimated the flooded area at 0.02 acres or 92 percent less than the estimate using the complete data set. The increase in error occurred because as total area decreases, discrepancies in area estimates become proportionally larger. Moreover, the transect data sets were more likely to exclude the lowest elevation in the wetland. At GS Marsh, the minimum elevation used in the transect data set was $92.33 \mathrm{ft}$ above NGVD of 1929. The lowest elevation used in the complete data set was $92.25 \mathrm{ft}$ above NGVD of 1929. At W-29
Marsh, the transects traversed the deepest point in the wetland so the lowest elevation value in both the transect data set and the complete data set was the same. In contrast, the elevation of the wetland perimeter, or highest stage, and its location were determined independently of the bathymetric mapping and were consistent at a given wetland regardless of the mapping approach. For this reason, the values of predicted area tended to converge for all approaches as the stage approached 100 percent full (figs. 14A-15A).

Adding one elevation contour to the transect data sets greatly improved the accuracy of the flooded-area predictions for both wetland shapes, but flooded-area predictions made with transects and a contour line still tended to be lower than 

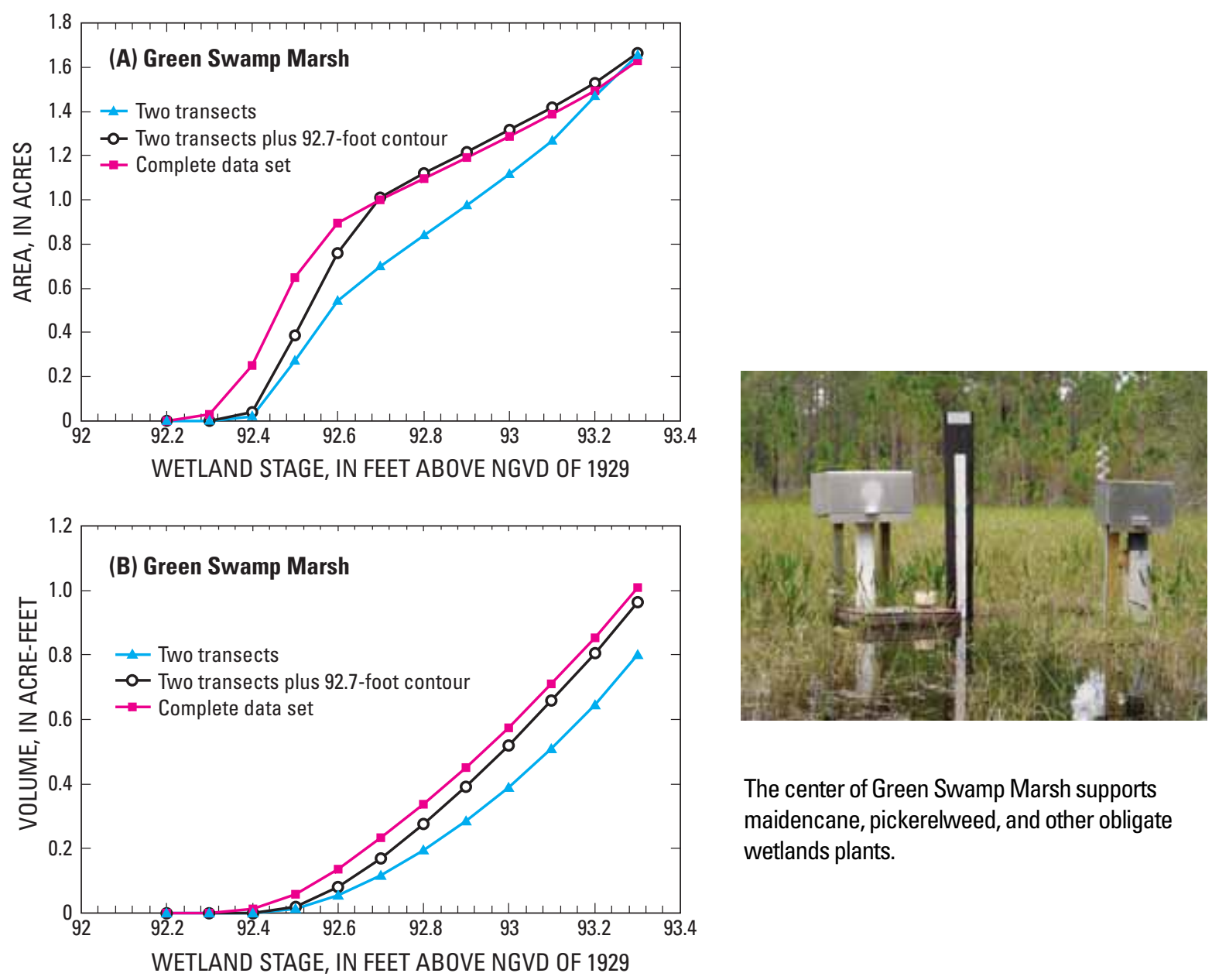

The center of Green Swamp Marsh supports maidencane, pickerelweed, and other obligate wetlands plants.

Figure 15. Effects of a reduced density of bathymetric data points at Green Swamp Marsh on (A) stage-area and (B) stage-volume relations.

those made using the complete data set. Contours added inside the wetland perimeters of W-29 Marsh (fig. 12C) and GS Marsh (fig. 13C) denoted the outline of the flooded area at an intermediate stage below the perimeter. For example, at W-29 Marsh, a contour line was added at $68.10 \mathrm{ft}$ above NGVD of 1929.

The addition of this contour reduced the error in flooded-area estimates at a stage of $68.02 \mathrm{ft}$ above NGVD of 1929 from 49 percent to 16 percent (fig. 14A). At GS Marsh, the contour was added at $92.70 \mathrm{ft}$ above NGVD of 1929. The addition of this contour decreased the error in the estimated flooded area at a stage of $92.60 \mathrm{ft}$ from 40 percent to about 16 percent (fig. $15 \mathrm{~A})$. The added contours tended to make the most improvement in the estimated areas at stage values equal to or greater than the elevation of the added contour.
At both wetlands, the simple mapping approach using transect data alone tended to predict substantially less wetland volume at a given stage than using the complete data set obtained from the Topcon mapping approach (fig. 14B, 15B). At W-29 Marsh, the wetland volume estimated at a stage of $68.02 \mathrm{ft}$ using the complete data set was 0.66 acre-ft. The wetland volume estimated using transect data alone was 0.40 acre- $\mathrm{ft}$ (about 39 percent less), and the volume estimated from the transect data with the contour line was 0.47 acre-ft (about 28 percent less). Filling the wetland to the perimeter required a water volume of 9.42 acre-ft, based on data obtained from the Topcon mapping approach. The volume estimated using transect data alone was about 20 percent less ( 7.69 acre-ft), whereas the volume estimated using the transect data and the 
additional contour line was 9.03 acre-ft (4 percent less). Similarly at GS Marsh, the discrepancies in estimated wetland volume were greatest using the transect data alone. The differences in estimated wetland volume between the complete data set and the other two data sets were greatest at smaller wetland volumes and were reduced as the wetland volume approached 100 percent inundation. The addition of a contour to the transect data method greatly improved the accuracy of wetland volume estimates. For example, when GS Marsh is full, the wetland holds a volume of 1.01 acre-ft based the data obtained from the Topcon mapping approach. Using transect data with an additional contour line provided an approximation within 5 percent of this volume ( 0.96 acre-ft), whereas the transect data alone underestimated the volume by about 20 percent ( 0.80 acre-ft).

Twelve months of daily stage data were analyzed using the three different stage-area relations developed for W-29 Marsh and GS Marsh. The weekly average percent area of inundation was plotted for the two sites (fig. 16A,B). The weekly average flooded areas estimated using the complete data sets are shown as vertical bars in figure 16. The estimates of flooded areas derived from the two simpler mapping approaches using data sets with fewer points also are shown for comparison.

Plots of the weekly average flooded area using the complete data sets (fig. 16) also highlight differences in the amount of flooded area occurring in the two wetlands during the same period of time (October 2001 - September 2002). At GS Marsh, which has not been affected by human activities, more than 60 percent of the wetland area was inundated for about 9 months of the year (fig. 16A). In contrast at W-29 Marsh, which has been affected by well field development, about 50 percent of the wetland was inundated for about 2 months of the year, and the entire wetland was dry for more than 8 months of the year (fig. 16B).

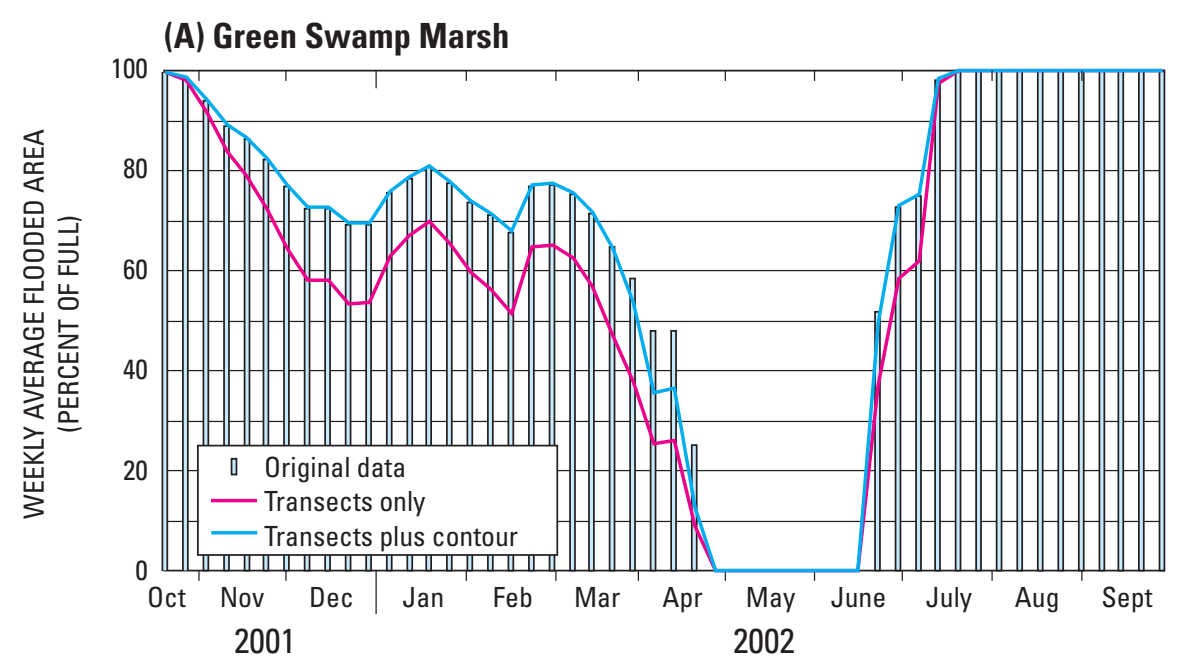

(B) W-29 Marsh

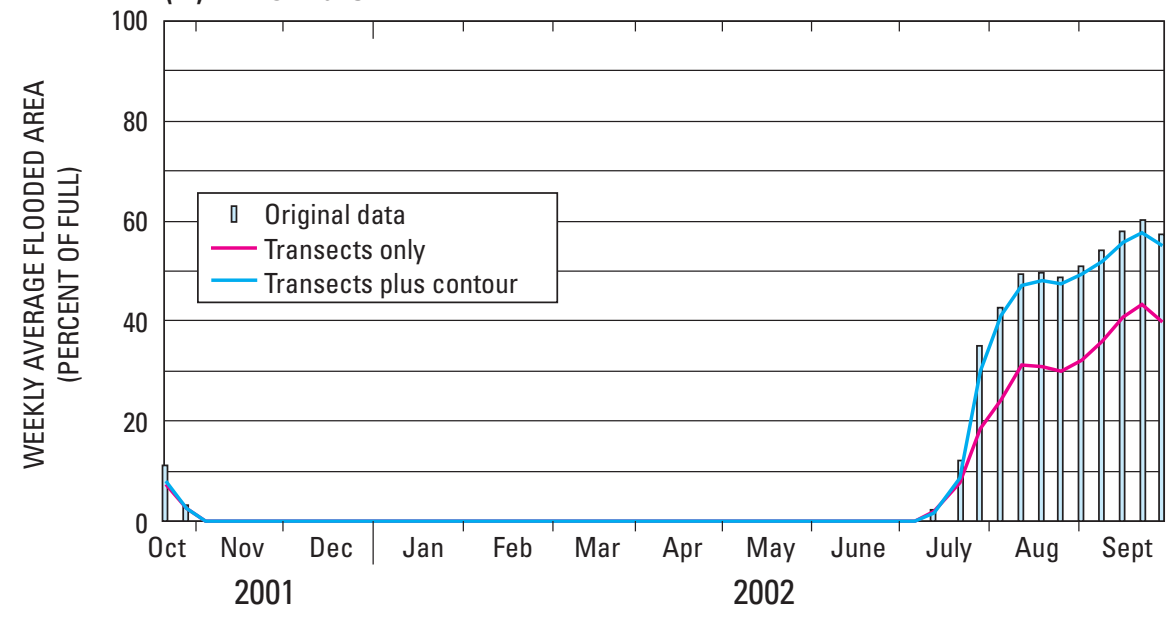

Figure 16. Changes in weekly average flooded area over time at Green Swamp Marsh and W-29 Marsh. 


\section{Relative Abundance of Wetland Plants in Fixed Plots}

In all 10 wetlands, vegetation growing in deep, intermediate, and transition plots was assessed semiannually from May 2002 to May 2004. Wetland water levels in May 2002 were distinctly lower than wetland water levels measured in the subsequent four assessments. Two factors most likely were responsible for the unanticipated water-level differences: rainfall amounts and the volume of ground-water withdrawal in well fields. During 2000-2002, rainfall in the west-central part of Florida was below average (Southwest Florida Water Management District, 2003b). During the latter part of 2002 and continuing through 2004, however, rainfall was above average (Southwest Florida Water Management District, 2003b). Moreover, with regard to the four wetlands located on the Cypress Creek well field (W-03 Marsh, W-05 Cypress, W-19 Cypress, and W-29 Marsh), there were effects on wetland water levels from a reduction in ground-water withdrawal rates beginning in 2003 (Tampa Bay Water, 2003). All of these conditions were reflected in the vegetation in the wetlands. Therefore, results of the initial vegetation assessment made during May 2002 (henceforth referred to as the "dry period") are reported separately, and results of the other four semiannual assessments (October 2002, May 2003, October 2003, and May 2004) (referred to as the "wet period") are combined and reported together in the vegetation tables.

The five semiannual vegetation assessments completed during this study produced lists of wetland plant species found in the 15 fixed plots at known elevations in each of the 10 wetlands. Although these lists are not exhaustive, the most common species found in this study have also been reported previously in these wetlands by the SWFWMD, Tampa Bay Water, and others during the previous one to two decades of periodic routine vegetation monitoring in well fields, parks, and other public areas in the NTB area (Rochow, 1994; Berryman and Henigar, 2001; Biological Research Associates, Inc., 2001; Reynolds, Smith \& Hills, Inc., 2001). SWFWMD in conjunction with Tampa Bay Water developed a Wetlands Assessment Procedure (WAP) in 1999 (Tampa Bay Water, 2000) to monitor ecological changes in a large number of wetlands in the NTB area. One component of the WAP, which currently is in use in more than 500 wetlands, evaluates vegetation trends by periodically assessing the percent cover, composition, and zonation of ground cover, shrubs, and trees along a transect line in each target wetland. Vegetation documented by SWFWMD in WAP evaluations during 2003 in the 10 wetlands described in this report is similar to vegetation found in USGS fixed plots in 2003 (Ted Rochow, SWFWMD, written commun., 2004).

\section{Natural Marsh Wetlands}

GS Marsh (fig. 4) and HRSP Marsh (fig. 5) are small isolated natural marsh wetlands that are similar to each other in basin size, shape, and bathymetry, and their surface-water levels have remained largely unaffected by human activities. Both wetlands typically are dry during the late-winter and spring, and the Serenoa repens (palmetto) fringe is well developed. The plant communities in these marshes consist primarily of OBL and FACW native wetland plants, which are well-adapted to the natural hydrologic regime. Continuous vegetation monitoring during 1977-1982 indicated that there was little or no terrestrial plant invasion at HRSP Marsh (Lopez, 1983), and more recent annual monitoring confirms these observations (Ted Rochow, SWFWMD, oral commun., 2002). There is a small, naturally occurring knoll near the center of HRSP Marsh where the elevation is slightly higher than the surrounding marsh, and where Acer rubrum (FACW) became established beginning in the 1970s (Mumme, 1978; Lopez, 1980).

In May 2002, deep plots in both wetlands contained no standing water, although the soil was saturated. Panicum hemitomon (OBL), the dominant plant, covered 25-50 percent of deep plots in both wetlands. Pontederia cordata (OBL) also was abundant in the deep plots at HRSP Marsh. Soils in intermediate plots of both wetlands were saturated to dry. Panicum hemitomon (OBL) and Eriocaulon compressum (OBL) were abundant in intermediate plots at GS Marsh, whereas Amphicarpum muhlenbergianum (FACW) and Rhynchospora inundata (OBL) were abundant in intermediate plots at HRSP Marsh. In transition plots at both sites, Amphicarpum muhlenbergianum (FACW) was abundant (tables 4A, 5A).

During the wet period, water depths were very similar in deep plots at both natural wetlands (about 8-12 inches). Abundant vegetation in deep plots at both sites (tables 4B, 5B) included the OBL species Panicum hemitomon, Pontederia cordata, Utricularia purpurea (at GS Marsh), and U. foliosa (at HRSP Marsh) (tables 4B, 5B). In intermediate and transition plots, water depth tended to be greater at GS Marsh than at HRSP Marsh during the wet period. Nearly all species found in intermediate plots at GS Marsh in the wet period were OBL plants, whereas plants in intermediate plots at HRSP included a mixture of OBL and FACW plants. The plant communities found in transition plots at both sites during October 2002 - May 2004 included a mixture of FAC, FACW, and OBL species.

\section{Impaired Marsh Wetland}

W-29 Marsh (fig. 11) is a relatively large, shallow marsh wetland located in the Cypress Creek Well Field. The marsh water-level regime reflects the ambient climate coupled with the cumulative effects of 25 years of ground-water pumping in the well field. The palmetto fringe is evident around much of the wetland perimeter. Water levels in the marsh have declined since 1979 when the well field achieved full-scale production (Reynolds, Smith \& Hills, Inc., 2001). Utricularia sp., Nymphoides sp., and other submersed and floating species declined in abundance soon after well-field production began and were replaced by emergent rushes and sedges. Amphicarpum muhlenbergianum and Hypericum myrtifolium were common in the marsh during the 1980s; encroachment by Andropogon sp. has occurred since 1995 (Reynolds, Smith \& Hills, Inc., 2001). 
Table 4. Vegetation in fixed plots in Green Swamp Marsh.

[Shaded species make up 10 percent or more of the vegetation cover in a plot]

\begin{tabular}{|c|c|c|}
\hline \multicolumn{3}{|c|}{ Depth below land-surface elevation at palmetto fringe ${ }^{1}$} \\
\hline $\begin{array}{c}\text { Transitional plots } \\
0-0.5 \text { feet }\end{array}$ & $\begin{array}{c}\text { Intermediate plots } \\
0.5-1.0 \text { feet }\end{array}$ & $\begin{array}{l}\text { Deep plots } \\
1.0-2.0 \text { feet }\end{array}$ \\
\hline \multicolumn{3}{|l|}{ A. May 2002} \\
\hline Amphicarpum muhlenbergianum (FACW) & Carex joorii (FACW) & \multirow[t]{5}{*}{ Panicum hemitomon (OBL) } \\
\hline Andropogon vivginicus (FAC) & Eriocaulon compressum (OBL) & \\
\hline Lachnanthes caroliana (FAC) & Panicum hemitomon (OBL) & \\
\hline Proserpinaca pectinata (OBL) & Proserpinaca pectinata (OBL) & \\
\hline Xyris fimbriata $(\mathrm{OBL})$ & Xyris fimbriata (OBL) & \\
\hline \multicolumn{3}{|c|}{ B. October 2002, May 2003, October 2003, and May 2004} \\
\hline Amphicarpum muhlenbergianum (FACW) & Carex verrucosa (FACW) & \multirow{9}{*}{$\begin{array}{l}\text { Carex verrucosa }(\mathrm{FACW}) \\
\text { Panicum hemitomon }(\mathrm{OBL}) \\
\text { Pontederia cordata }(\mathrm{OBL}) \\
\text { Utricularia purpurea }(\mathrm{OBL})\end{array}$} \\
\hline Andropogon virginicus (FAC) & Eriocaulon compressum (OBL) & \\
\hline Lachnanthes caroliana (FAC) & Panicum hemitomon (OBL) & \\
\hline Panicum hemitomon (OBL) & Proserpinaca pectinata (OBL) & \\
\hline Proserpinaca pectinata (OBL) & Saccharum giganteum (OBL) & \\
\hline Rhynchospora cephalantha (OBL) & Utricularia purpurea $(\mathrm{OBL})$ & \\
\hline Sagittaria graminea $(\mathrm{OBL})$ & & \\
\hline Utricularia purpurea (OBL) & & \\
\hline Xyris fimbriata $(\mathrm{OBL})$ & & \\
\hline
\end{tabular}

193.30 feet above NGVD of 1929.

Table 5. Vegetation in fixed plots in Hillsborough River State Park Marsh.

[Shaded species make up 10 percent or more of the vegetation cover in a plot; $>$, greater than]

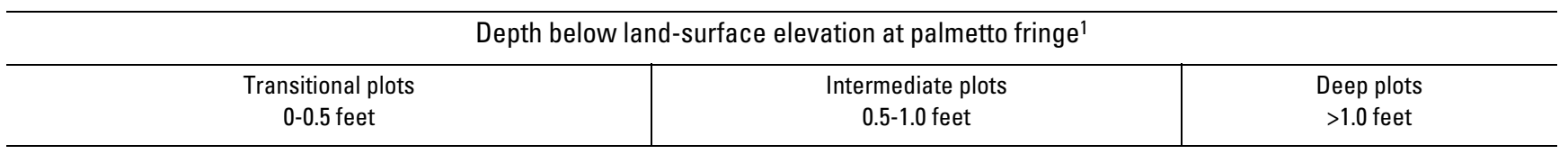

A. May 2002

\begin{tabular}{l|l|l}
\hline Amphicarpum muhlenbergianum (FACW) & $\begin{array}{l}\text { Amphicarpum muhlenbergianum }(\mathrm{FACW}) \\
\text { Andropogon virginicus }(\mathrm{FAC})\end{array}$ & $\begin{array}{l}\text { Panicum hemitomon }(\mathrm{OBL}) \\
\text { Pontederia cordata }(\mathrm{OBL})\end{array}$ \\
$\begin{array}{l}\text { Panicum hemitomon }(\mathrm{OBL}) \\
\text { Pluchea rosea }(\mathrm{FACW})\end{array}$ & & \\
\hline
\end{tabular}

B. October 2002, May 2003, October 2003, and May 2004

\begin{tabular}{l|l}
\hline $\begin{array}{l}\text { Amphicarpum muhlenbergianum (FACW) } \\
\text { Andropogon virginicus }(\mathrm{FAC})\end{array}$ & $\begin{array}{l}\text { Amphicarpum muhlenbergianum }(\mathrm{FACW}) \\
\text { Leersia hexandra }(\mathrm{OBL})\end{array}$ \\
$\begin{array}{l}\text { Juncus maiginatus }(\mathrm{FACW}) \\
\text { Leersia hexandra }(\mathrm{OBL})\end{array}$ & $\begin{array}{l}\text { Oxypolis filiformis }(\mathrm{OBL}) \\
\text { Panicum verrucosum }(\mathrm{FACW})\end{array}$ \\
Ludwigia linearis $(\mathrm{OBL})$ & Polygonum hydropiperoides $(\mathrm{OBL})$ \\
Panicum hemitomon $(\mathrm{OBL})$ & Proserpinaca pectinata $(\mathrm{OBL})$ \\
Panicum verrucosum $(\mathrm{FACW})$ & Rhynchospora inundata $(\mathrm{OBL})$ \\
Panicum virgatum $(\mathrm{FACW})$ & Sagittaria graminea $(\mathrm{OBL})$ \\
Pluchea rosea $(\mathrm{FACW})$ & Scleria baldwinii $(\mathrm{FACW})$ \\
Polygonum hydropiperoides $(\mathrm{OBL})$ & Utricularia foliosa $(\mathrm{OBL})$ \\
\hline
\end{tabular}

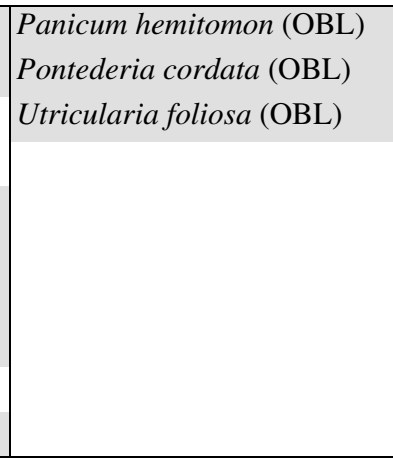

146.35 feet above NGVD of 1929. 
During May 2002, the entire wetland was dry, and vegetation was not similar to vegetation in any of the other marsh sites. In the deep plots, Eupatorium capillifolium (FAC) and dead stands of Panicum hemitomon (OBL) were abundant. The plant community in the intermediate plots consisted of an upland species (Conyza canadensis) and several abundant FACW and FAC species including Amphicarpum muhlenbergianum, Eupatorium capillifolium, and Andropogon virginicus, which was the only plant present in transition plots (table 6A).

Heavy rains during the autumn of 2002 and during much of 2003 inundated the deep and intermediate plots at W-29 Marsh, and OBL and FACW species were evident in subsequent vegetation assessments, presumably regrowing from the seed bank in the substrate (Brock and others, 2003). Water depths ranged from 24 inches in May 2003 to 36 inches in October 2003 in deep plots, where Panicum hemitomon (OBL) and Nymphaea odorata (OBL) were abundant (table 6B). Water depth in intermediate plots ranged from 12 inches (May 2003) to 26 inches (October 2003). Abundant plants included Euthamia caroliniana (FAC), Eupatorium capillifolium (FAC), Hypericum fasiculatum (OBL), Panicum hemitomon (OBL), Sagittaria graminea (OBL), and Utricularia purpurea (OBL). Transition plots had 2-3 inches of water in May 2003, 4-8 inches of water in October 2003, and were dry in May 2004.
The most abundant plants in these plots during 2003 included Panicum hemitomon (OBL) and Xyris fimbriata (OBL).

There has been an incursion of Pinus elliottii (slash pines) (upland) at W-29 Marsh. Photographs taken annually beginning in 1985 (Ted Rochow, SWFWMD, written commun., 2003) indicate that the slash pines began to appear sometime between 1991 and 1995, when conditions were dry. These slash pines presumably were seeded from slash pines in the surrounding landscape, and they became distributed throughout the marsh by 1998 (fig. 17). Although none of the slash pines were located in the vegetation plots established at the site, field observations during May 2002 - October 2003 (the wet period) indicate that most of the slash pine trees in the marsh had died. Wet conditions are stressful to young slash pines (less than 10 years old), and the slash pines in W-29 Marsh appeared to have died in response to inundation from the higher water levels, which began to occur during late 2002. Field data collected in January February 2004 indicate that the slash pine trees ranged in size from 0.78 inches dbh to 12.20 inches $\mathrm{dbh}$, with an average dbh of 4.7 inches. As of that date, all slash pines growing at or below an elevation of $68.42 \mathrm{ft}$ above NGVD of 1929 were dead. Of the nearly 120 trees assessed at the site growing at or below the palmetto fringe elevation (69.92 ft above NGVD of 1929), only 12 percent were still alive in January - February 2004.

Table 6. Vegetation in fixed plots in W-29 Marsh.

[Shaded species make up 10 percent or more of the vegetation cover in a plot; $>$, greater than]

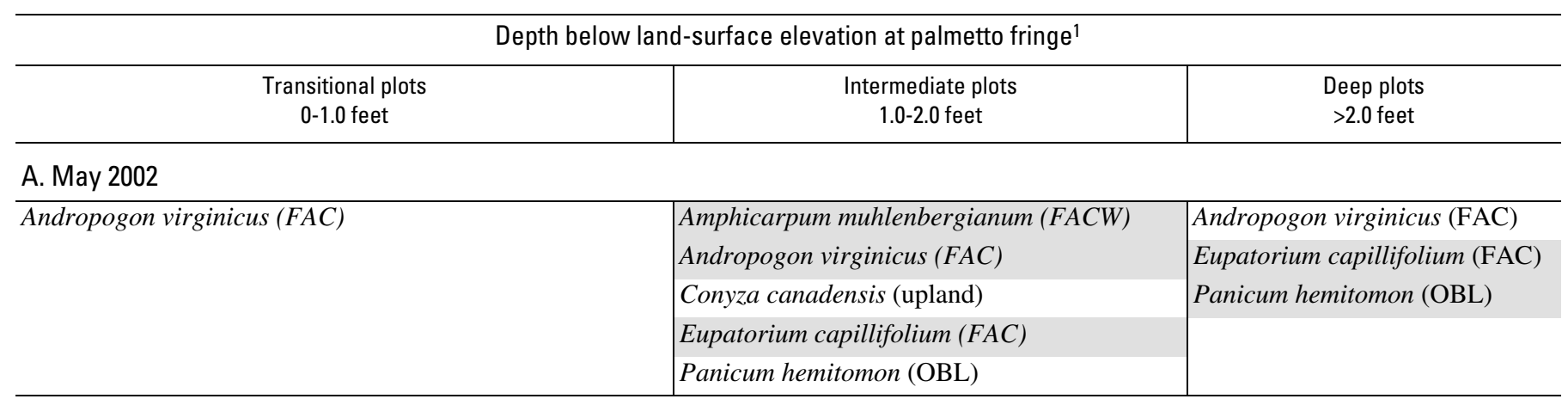

B. October 2002, May 2003, October 2003, and May 2004

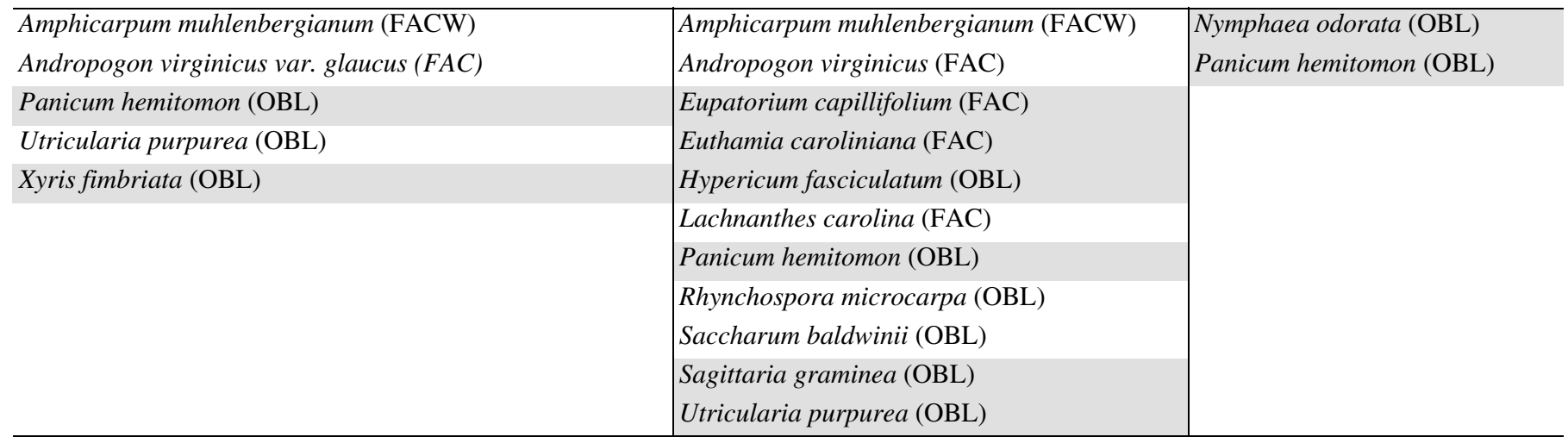

${ }^{1} 69.92$ feet above NGVD of 1929. 


\section{W-29 Marsh}

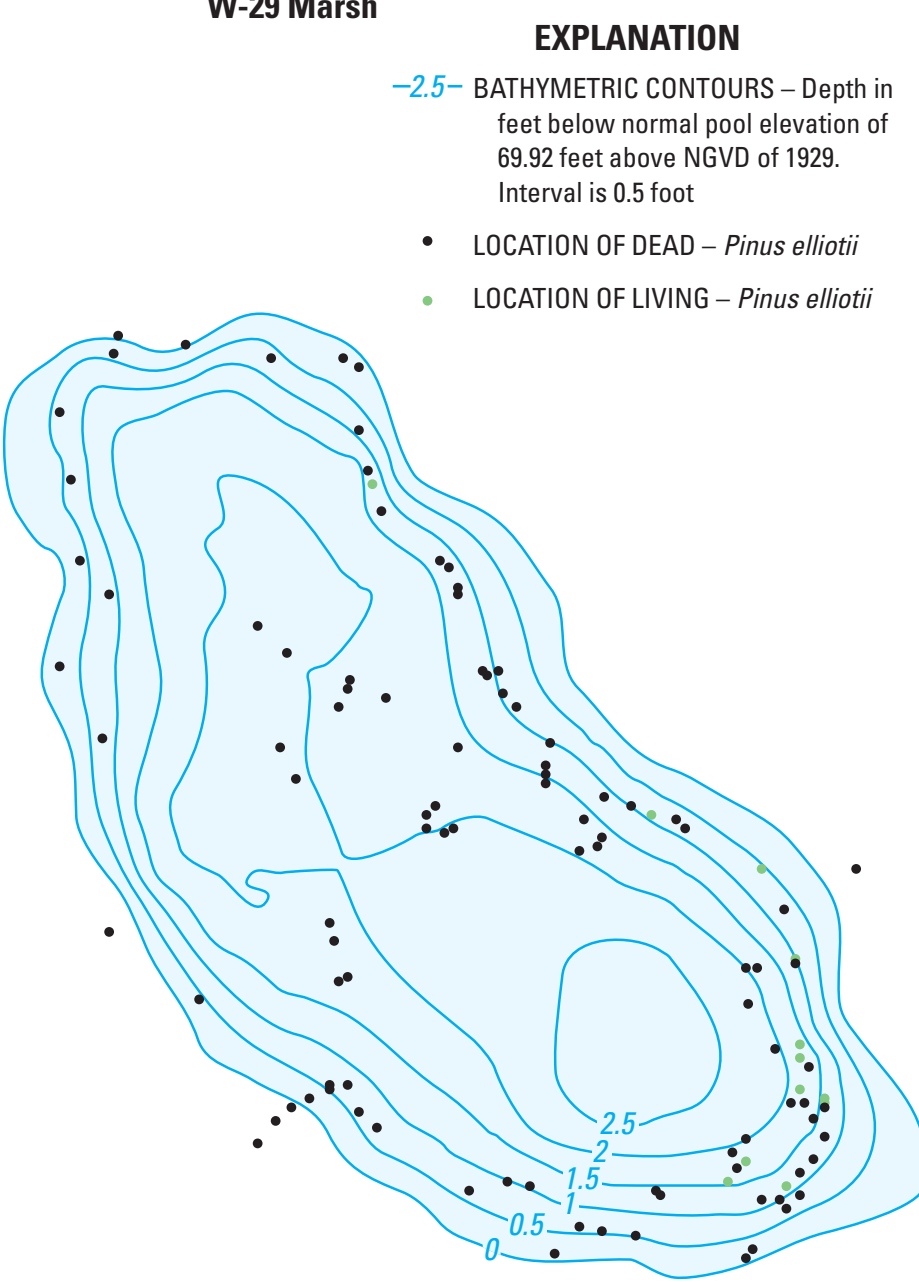

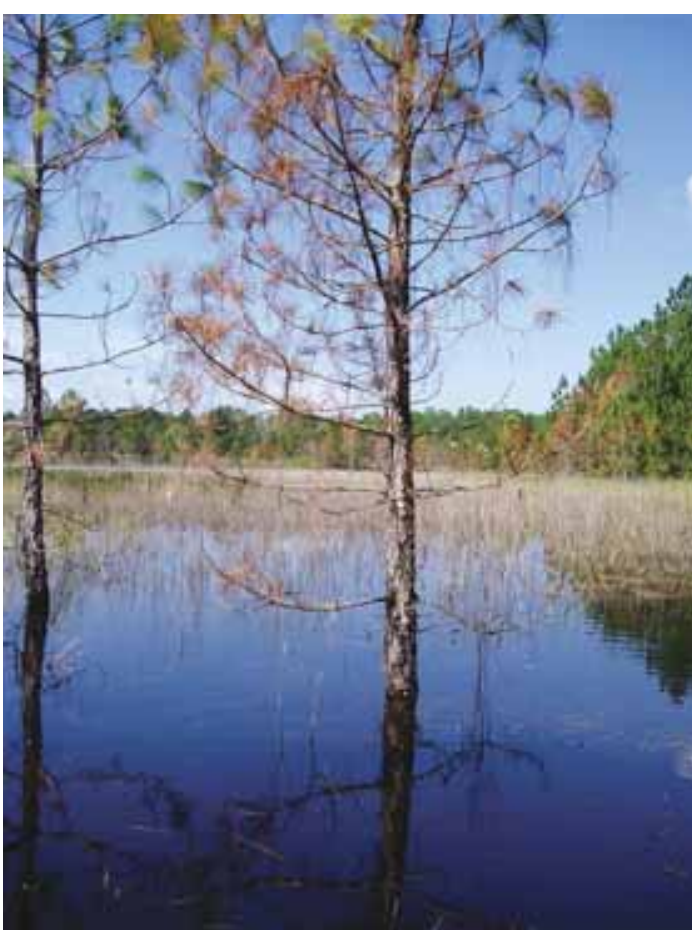

An 18-month period of high water at W-29 Marsh caused the death of slash pines that had encroached during more than 10 years of low water.

Figure 17. Distribution and status of Pinus elliotiit trees in W-29 Marsh during January-February, 2004.

\section{Augmented Marsh Wetlands}

W-03 (fig. 8) is a shallow, augmented marsh wetland with a small and relatively deep area that is inundated year-round. Before well-field operation began in 1976, W-03 Marsh contained a variety of broad-leaf emergent and floating wetland plants (Reynolds, Smith \& Hills, Inc., 2001). Soon after production began in 1976, water levels in the wetland declined and wetland soils became dry and fissured. Grasses and woody species quickly invaded the site (Reynolds, Smith \& Hills, Inc., 2001). Augmentation of W-03 Marsh with ground water began in 1978. Although water levels have varied, the marsh has never been allowed to dry out completely and a thick layer of partially decomposed vegetation (muck) has developed. Although water is below land surface throughout much of the marsh for many months each year, the thick organic muck substrate remains saturated and wetland vegetation is dense throughout those areas. Periphyton (attached algae) is abundant on aquatic plant stems and on the decomposing vegetation when water is in the marsh.
There are several areas covered with Typha latifolia (OBL) across the western part of the wetland, and isolated stands of Salix carolinana $(\mathrm{OBL})$ in the southern part of the wetland. Recent monitoring indicates that Typha latifolia is increasing its areal coverage (Reynolds, Smith \& Hills, Inc., 2001). Acer rubrum (FACW) is encroaching in several areas, particularly along the eastern edge of the wetland.

In May 2002 (the dry period), water depth was 8-10 inches in deep plots, and much of the western part of the wetland had no water at land surface. The plant community in deep plots included OBL species similar to those found in the natural marshes (Panicum hemitomon, Sagittaria latifolia, and Nymphaea odorata) (table 7A). Intermediate plots were saturated (no standing water) and abundant OBL species included Sagittaria latifolia and Panicum hemitomon. In transition plots along the shallow margins of the wetland, Callicarpa americana (upland) was abundant. Numerous FAC species and the vine Berchemia scandens contributed to the dense foliage cover. 
Table 7. Vegetation in fixed plots in W-03 Marsh.

[Shaded species make up 10 percent or more of the vegetation cover in a plot; >, greater than; --, not determined]

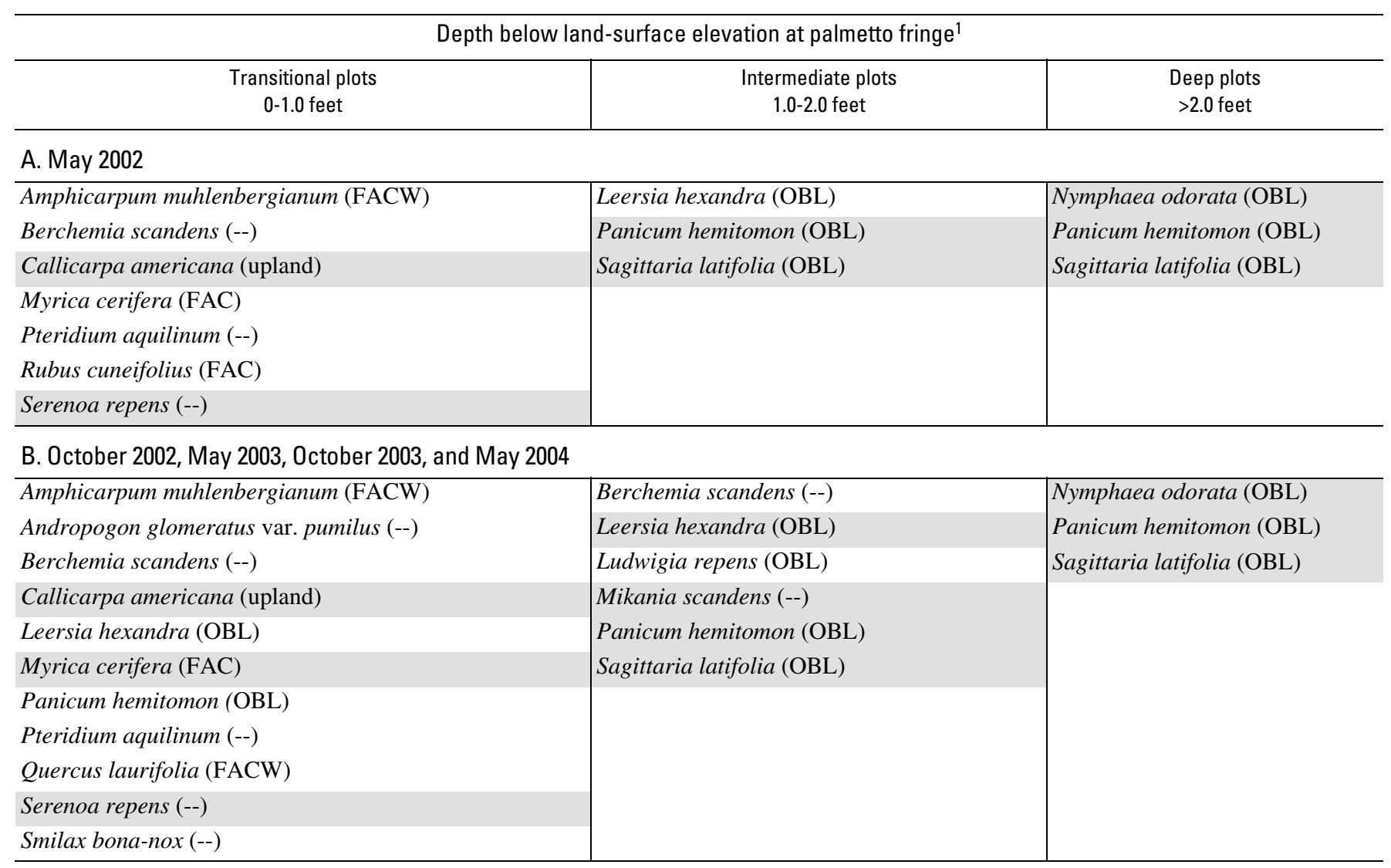

172.44 feet NGVD of 1929.

Water levels in W-03 were much deeper during the wet period (October 2002 - May 2004) than during the previous dry period. In October 2003, water depths were 26-34 inches in the deep plots, and 15-17 inches in the intermediate plots. The plant community in deep and intermediate plots, however, consisted of OBL species, and did not change appreciably from what was found in May 2002. The soil in the transition plots was dry in May 2004, and despite wetter weather the plant community was similar to that found in May 2002.

Duck Pond Marsh (fig. 2) is a deep (mean depth $3.20 \mathrm{ft}$ ), augmented marsh wetland located in the Cross Bar Ranch Well Field. There is no palmetto fringe because of past and present land-management practices. The well field was constructed in 1979 and ground-water withdrawal for public supply began in 1980. Before ground-water withdrawal, Duck Pond Marsh contained a variety of broad-leaf emergent and floating wetland plants (Biological Research Associates, Inc., 2001). Augmentation of Duck Pond Marsh with ground water began in 1987. Since 1997, the marsh water level has typically been kept between 67.2 and $70.4 \mathrm{ft}$ above NGVD of 1929, providing continuous inundation of 45-98 percent of the wetland in order to provide year-round wildlife habitat in the well field (Dave Slonena, Pinellas County, written commun., 2004). Duck Pond
Marsh does not have Panicum hemitomon (a characteristic marsh species) in the deep plots because of its uniformly greater depth compared to the natural marshes in this study. A thick layer of unconsolidated, partially decomposed vegetation has accumulated on the wetland bottom since augmentation began. Periphyton is abundant on macrophyte stems and on the decomposing vegetation substrate.

In May 2002, vegetation in deep plots consisted of OBL floating and emergent vegetation including Nuphar advena, Nymphoides aquatica, Sagittaria latifolia, and Eleocharis equisetoides (table 8A). Chara sp. (musk grass), a species that typically is found in calcium carbonate-enriched waters, was abundant in deep plots. In the intermediate plots in May 2002, there was no standing water. The vegetation was a mix of OBL plants (Eleocharis equisetoides, Leersia hexandra, and Sagittaria latifolia), FACW plants (Amphicarpum muhlenbergianum and Hydrocotyle umbellata), and FAC plants (Andropogon virginicus and Phyla nodiflora). Transition plots were dry during May 2002 and FAC plants such as Phyla nodiflora were abundant.

During the wet period, the plant community in deep plots was similar to that found in May 2002 (table 8B), although Eleocharis vivipara (OBL) also was abundant in May 2004. 
28 Bathymetry and Vegetation in Isolated Marsh and Cypress Wetlands in the Northern Tampa Bay Area, 2000-2004

Table 8. Vegetation in fixed plots in Duck Pond Marsh.

[Shaded species make up 10 percent or more of the vegetation cover in a plot; >, greater than; --, not determined]

\begin{tabular}{c|c|c}
\hline \multicolumn{3}{c}{ Depth below land-surface elevation at hydric-soils indicator ${ }^{1}$} \\
\hline Transitional plots & Intermediate plots & Deep plots \\
$0.0-2.0$ feet & $2.0-4.0$ feet & $>4.0$ feet \\
\hline
\end{tabular}

A. May 2002

\begin{tabular}{|c|c|c|}
\hline Andropogon virginicus (FAC) & Amphicarpum muhlenbergianum (FACW) & Chara sp. (--) \\
\hline Erigeron quercifolius (FAC) & Andropogon virginicus (FAC) & Eleocharis equisetoides (OBL) \\
\hline Phyla nodiflora (FAC) & Centella asiatica (FACW) & Nuphar aduena (OBL) \\
\hline Rhynchospora microcarpa (OBL) & $\begin{array}{l}\text { Cyperus haspan (OBL) } \\
\text { Eleocharis equisetoides (OBL) } \\
\text { Hydrocotyle umbellata (FACW) } \\
\text { Leersia hexandra }(\mathrm{OBL}) \\
\text { Mikania scandens }(--) \\
\text { Phyla nodiflora (FAC) } \\
\text { Sagittaria latifolia }(\mathrm{OBL})\end{array}$ & $\begin{array}{l}\text { Nymphoides aquatica (OBL) } \\
\text { Sagittaria latifolia }(\mathrm{OBL})\end{array}$ \\
\hline
\end{tabular}

B. October 2002, May 2003, October 2003, and May 2004

\begin{tabular}{|c|c|c|}
\hline Amphicarpum muhlenbergianum (FACW) & Chara sp. (--) & Chara sp. (--) \\
\hline Andropogon glomeratus var. pumilus (--) & Centella asiatica (FACW) & Eleocharis equisetoides (OBL) \\
\hline Andropogon virginicus (FAC) & Cyperus haspan (OBL) & Eleocharis vivipara $(\mathrm{OBL})$ \\
\hline Centella asiatica (FACW) & Eleocharis equisetoides (OBL) & Nuphar advena (OBL) \\
\hline Erigeron quercifolius (FAC) & Fuirena squarrosa (OBL) & Nymphoides aquatica (OBL) \\
\hline Fuirena squarrosa (OBL) & Hydrocotyle umbellata (FACW) & Sagittaria latifolia (OBL) \\
\hline Hydrocotyle umbellata (FACW) & Leersia hexandra (OBL) & \\
\hline Ludwigia microcarpa (OBL) & Mikania scandens (--) & \\
\hline Panicum hemitomon (OBL) & Panicum hemitomon (OBL) & \\
\hline Panicum rigidulum (FACW) & Proserpinaca palustris (OBL) & \\
\hline Phyla nodiflora (FAC) & Sagittaria latifolia (OBL) & \\
\hline Rhynchospora microcarpa (OBL) & & \\
\hline
\end{tabular}

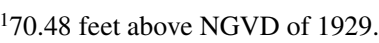

Water depth in intermediate plots was much greater during the wet period (16-18 inches) than in May 2002, when intermediate plots were dry. Abundant vegetation included many of the same OBL species, with the addition of Fuirena squarrosa and Panicum hemitomon, but FAC species were not found. Transition plots were still dry during May 2004. Although there was no standing water in these plots, OBL plants such as Fuirena squarrosa, Ludwigia microcarpa, and Rhynchospora microcarpa, and the FACW species Panicum rigidulum were abundant.

\section{Natural Cypress Wetlands}

Green Swamp Cypress (fig. 3) is a natural wetland in which water levels fluctuate seasonally, sustaining healthy stands of Taxodium ascendens (OBL) and maintaining a welldeveloped palmetto fringe (Rochow and Lopez, 1984). Lyonia lucida (FACW) is widespread on cypress buttresses. GS Cypress is largely unaffected by human activities that can affect groundwater levels.
During May 2002, there was no standing water in GS Cypress. Taxodium ascendens (OBL) and Cephalanthus occidentalis (OBL) were the only plants present in deep plots in the wetland. Lyonia lucida (FACW) and Woodwardia virginica (FACW) were present in intermediate plots. In the transition plots FAC (Lachnanthes caroliniana) and FACW (Woodwardia virginica and Lyonia lucida) species were abundant (table 9A).

Although water depths were much greater during the wet period than during the dry period at GS Cypress (16-21 inches in deep plots; 8-10 inches in intermediate plots), the vegetation community remained virtually the same in these plots during both periods. The absence of nonwoody vegetation in deep and intermediate plots may be a result of the relatively high tree density in the wetland and the deep, darkly stained water in the wetland center, which may naturally inhibit growth of rooted aquatic plants. In transition plots, water depth was 1-3 inches. Ludwigia lanceolata (OBL) was found in October 2003, in response to increased water levels occurring in the wet period (table 9B). 
Table 9. Vegetation in fixed plots in Green Swamp Cypress.

[Shaded species make up 10 percent or more of the vegetation cover in a plot; >, greater than; --, not determined]

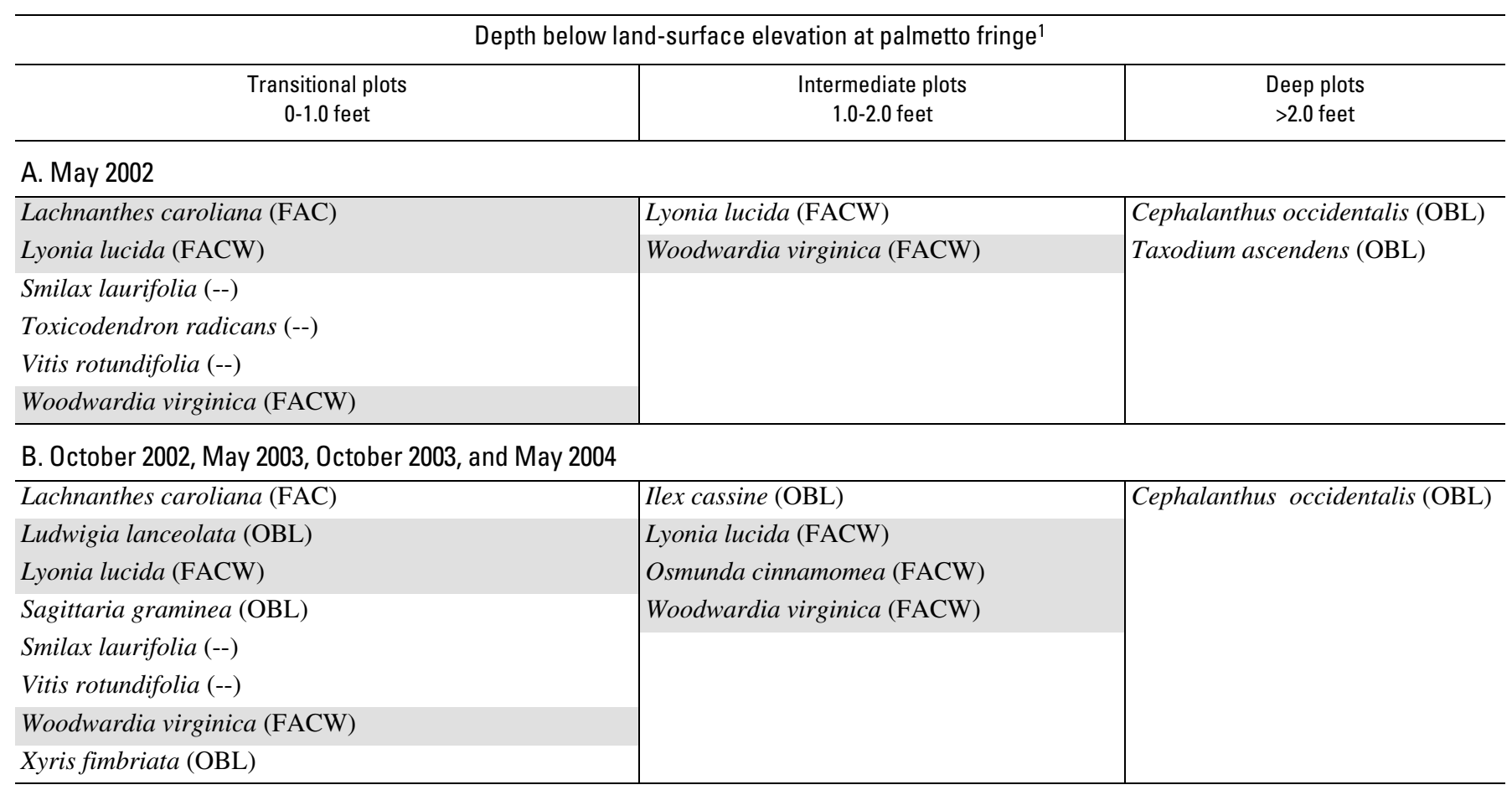

198.56 feet above NGVD of 1929.

S-68 Cypress (fig. 7) is a natural wetland located in the Jay B. Starkey Wilderness Park. S-68 Cypress is in a part of the park far removed from production wells. It is unlikely that the wetland was affected by municipal ground-water withdrawals from the well field during 2002-2003, because of its remote location. In June 2000, there was evidence of soil subsidence (Berryman and Henigar, Inc., 2001), but this subsidence was most likely due to seasonal dry conditions rather than land-use activities. There is more herbaceous vegetation in S-68 Cypress compared to GS Cypress, perhaps because it has a more open tree canopy.

In May 2002, all plots were dry at S-68 Cypress. The plant community in deep plots included Panicum hemitomon (OBL) and Rhynchospora corniculata (OBL). In intermediate plots, OBL (Hypericum fasiculatum) and FACW (Coelorachis rugosa), plants were abundant (table 10A). Andropogon virginicus (FAC) was abundant in transition plots.

In the wet period, water levels throughout the wetland were much higher than during the dry period. In October 2003, the deep plots had 15-16 inches of water, and the OBL plants Panicum hemitomon and Utricularia purpurea were abundant (table 10B). Intermediate plots contained 7-8 inches of water; FACW (Coelorachis rugosa) and OBL plants (Panicum hemitomon and Utricularia purpurea) were abundant. Transition plots were saturated at land surface, but the plant community was similar to the May 2002 assessment.

\section{Impaired Cypress Wetland}

W-19 Cypress (fig. 10) is an impaired wetland affected by ground-water withdrawal and other activities in the Cypress Creek Well Field. Before ground-water withdrawal, W-19 Cypress contained a healthy stand of Taxodium ascendens, as well as OBL (Cladium jamaicense and Pontederia cordata), and FACW species (Blechnum serrulatum, Woodwardia virginica, and Rhynchospora sp.) (Reynolds, Smith, \& Hills, Inc., 2001). Well-field production began in 1976, and water levels in W-19 Cypress have declined since that time. Water levels in the swamp fluctuate seasonally; however, water has been typically below land surface during many months of the year. There has been tree fall of Taxodium ascendens in the wetland. Machinery used to cut a firebreak through the wetland in 2002 grazed numerous trees and contributed to tree mortality. Acer rubrum (FACW) and Quercus laurifolia $(\mathrm{FACW})$ are now found growing in the wetland.

All plots were dry in May 2002. In the deep plots, Paspalum repens (OBL) and Carex longii (FACW) were abundant (table 11A). The intermediate and transition plots contained very little herbaceous vegetation. The wetland became inundated during the wet period beginning in October 2002. By October 2003, floating (Lemna obscura) and submersed (Utricularia foliosa, and $U$. inflata) OBL plants were abundant in the deep plots (table 11B), where water depth was 29-32 inches. These two species also were present in intermediate plots (water depth 10-17 inches). In transition plots, Serenoa repens (overhanging, but not rooted in the plots) remained the only abundant species. 
Table 10. Vegetation in fixed plots in S-68 Cypress.

[Shaded species make up 10 percent or more of the vegetation cover in a plot; >, greater than; --, not determined]

Depth below land-surface elevation at palmetto fringe ${ }^{1}$

\begin{tabular}{c|c|c}
\hline Transitional plots & Intermediate plots & Deep plots \\
$0-1.0$ feet & $1.0-2.0$ feet & feet \\
\hline
\end{tabular}

\section{A. May 2002}

\begin{tabular}{|c|c|c|}
\hline Amphicarpum muhlenbergianum (FACW) & Aristida palustris (OBL) & Panicum hemitomon $(O B L)$ \\
\hline Andropogon virginicus (FAC) & Coelorachis rugosa (FACW) & Rhynchospora corniculata (OBL) \\
\hline Aristida stricta var. beyrichiana (FAC) & \multirow{7}{*}{$\begin{array}{l}\text { Eupatorium capillifolium (FAC) } \\
\text { Dichanthelium erectifolium }(\mathrm{OBL}) \\
\text { Hypericum fasciculatum }(\mathrm{OBL}) \\
\text { Panicum hemitomon }(\mathrm{OBL}) \\
\text { Pluchea rosea }(\mathrm{FACW})\end{array}$} & \\
\hline Dichanthelium ensifolium var. unciphyllum (FAC) & & \\
\hline Hypericum fasciculatum (OBL) & & \\
\hline Hypericum myrtifolium (FACW) & & \\
\hline Ilex glabra (--) & & \\
\hline Lachnanthes caroliana (FAC) & & \\
\hline Serenoa repens $(--)$ & & \\
\hline \multicolumn{3}{|l|}{ B. October 2002, May 2003, October 2003, and May 2004} \\
\hline Amphicarpum muhlenbergianum (FACW) & Aristida condensata (--) & Panicum hemitomon (OBL) \\
\hline Andropogon virginicus (FAC) & Aristida palustris (OBL) & Rhynchospora corniculata (OBL) \\
\hline Andropogon virginicus var. glaucus (FAC) & Coelorachis rugosa (FACW) & Utricularia purpurea $(\mathrm{OBL})$ \\
\hline Aristida stricta var. beyrichiana (FAC) & \multirow{7}{*}{$\begin{array}{l}\text { Hypericum fasciculatum (OBL) } \\
\text { Panicum hemitomon }(\mathrm{OBL}) \\
\text { Utricularia purpurea }(\mathrm{OBL})\end{array}$} & \\
\hline Dichanthelium ensifolium var. unciphyllum (FAC) & & \\
\hline Hypericum fasciculatum (OBL) & & \\
\hline Hypericum myrtifolium (FACW) & & \\
\hline Ilex glabra (--) & & \\
\hline Lachnanthes caroliana (FAC) & & \\
\hline Serenoa repens (--) & & \\
\hline
\end{tabular}

${ }^{143.66}$ feet above NGVD of 1929.

Table 11. Vegetation in fixed plots in W-19 Cypress.

[Shaded species make up 10 percent or more of the vegetation cover in a plot; $>$, greater than; --, not determined]

\begin{tabular}{c|c|c}
\hline \multicolumn{3}{c}{ Depth below land-surface elevation at palmetto fringe } \\
\hline Transitional plots & Intermediate plots & Deep plots \\
$0-1.0$ feet & $1.0-2.0$ feet & $>2.0$ feet \\
\hline
\end{tabular}

A. May 2002

Melothria pendula (--)

Serenoa repens (--)

Toxicodendron radicans (--)

\begin{tabular}{|l|l|} 
Acer rubrum (FACW) & Carex longii $(\mathrm{FACW})$ \\
Dichanthelium ensifolium var. unciphyllum & Paspalum repens $(\mathrm{OBL})$ \\
(FAC) & Pichanthelium sp. (--) \\
$\begin{array}{l}\text { Myrica cerifera } \text { (FAC) } \\
\text { Toxicodendron radicans (--) }\end{array}$ & \\
\hline
\end{tabular}

B. October 2002, May 2003, October 2003, and May 2004

Carex verrucosa $(\mathrm{FACW})$
Habenaria floribunda $(\mathrm{FACW})$
Mikania scandens $(--)$
Serenoa repens $(--)$
Toxicodendron radicans $(--)$

${ }^{1} 61.99$ feet above NGVD of 1929.

\begin{tabular}{|l|l}
\hline Lemna obscura $(\mathrm{OBL})$ & Carex longii $(\mathrm{FACW})$ \\
Utricularia foliosa $(\mathrm{OBL})$ & Lemna obscura $(\mathrm{OBL})$ \\
Utricularia inflata $(\mathrm{OBL})$ & $\begin{array}{l}\text { Utricularia foliosa }(\mathrm{OBL}) \\
\text { Utricularia inflata }(\mathrm{OBL})\end{array}$ \\
\hline
\end{tabular}




\section{Augmented Cypress Wetlands}

S-63 Cypress (fig. 6) is a shallow, augmented wetland located in the Jay B. Starkey Wilderness Park. The wetland was dry for extended periods of time after well-field production began in 1974, and there was evidence of soil subsidence and compaction (Berryman and Henigar, 2001). Augmentation of the wetland began in 1990. Even with augmentation, the water level is below land surface for many months of the year. The canopy is dominated by Taxodium ascendens. This site had a greater diversity of plant species (greater than 35) than any of the other cypress sites in the study. Contributing factors could be the relatively low tree density, which allows greater light penetration to the wetland floor, and shallow but intermittent water levels, which facilitate germination and growth of many wetland plants.

During May 2002, deep plots had saturated soil, whereas transition and intermediate plots were dry. Dense vegetation in deep and intermediate plots included a mix of OBL, FACW, and FAC species. Abundant species included Aster elliotii (OBL), Lycopus rubellus (OBL), Rhynchospora corniculata
(OBL), and Pluchea odorata (FACW) (table 12A). In the transition plots, abundant species included Andropogon virginicus (FAC) and Myrica cerifera (FAC).

During the wet period, water levels in the wetland varied, and declined quickly when the augmentation pump was not operating. Water depth in deep plots ranged from less than 1 to 15 inches, and intermediate plots ranged from dry to a water depth of 9 inches. Aster elliottii (OBL) was found throughout the wetland and commonly filled 20-60 percent of deep and intermediate plots (table 12B). More OBL species were found in deep plots during October 2002 - May 2004 than during May 2002 , in response to deeper water. In contrast, vegetation did not differ greatly in intermediate plots between the May 2002 dry period and the wet period. In transition plots, OBL species such as Rhynchospora microcarpa and $R$. miliacea were abundant during October 2002 - May 2004.

W-05 Cypress (fig. 9) is an augmented wetland located in the Cypress Creek Well Field. Before ground-water withdrawal, W-05 Cypress was a forested wetland dominated by Taxodium ascendens, and Eriocaulon sp. (pipeworts) were abundant in the wetland. W-05 Cypress has been augmented

Table 12. Vegetation in fixed plots in S-63 Cypress.

[Shaded species make up 10 percent or more of the vegetation cover in a plot; $>$, greater than; --, not determined]

\begin{tabular}{c|c|c}
\hline \multicolumn{3}{c}{ Depth of plots below land-surface elevation at palmetto fringe ${ }^{1}$} \\
\hline Transitional plots \\
$0-0.5$ feet & Intermediate plots & Deep plots \\
$>1.0$ feet
\end{tabular}

A. May 2002

Amphicarpum muhlenbergianum (FACW)

Andropogon virginicus (FAC)

Aristida stricta var. beyrichiana (FAC)

Aster elliottii (OBL)

Blechnum serrulatum (FACW)

Myrica cerifera (FAC)

Rubus cuneifolius (FAC)

B. October 2002, May 2003, October 2003, and May 2004

\begin{tabular}{|c|c|c|}
\hline Acer rubrum (FACW) & Acer rubrum (FACW) & Aster elliottii (OBL) \\
\hline Amphicarpum muhlenbergianum (FACW) & Aster elliottii (OBL) & Blechnum serrulatum (FACW) \\
\hline Andropogon virginicus (FAC) & Coelorachis rugosa (FACW) & Coelorachis rugosa (FACW) \\
\hline Aster elliottii (OBL) & Lycopus rubellus (OBL) & Ludwigia repens $(\mathrm{OBL})$ \\
\hline Myrica cerifera (FAC) & Mikania scandens (--) & Mikania scandens (--) \\
\hline Panicum hemitomon (OBL) & \multirow{6}{*}{$\begin{array}{l}\text { Myrica cerifera }(\mathrm{FAC}) \\
\text { Panicum hemitomon }(\mathrm{OBL}) \\
\text { Rhynchospora miliacea }(\mathrm{OBL}) \\
\text { Saccharum baldwinii }(\mathrm{OBL}) \\
\text { Woodwardia virginica }(\mathrm{FACW})\end{array}$} & Myrica cerifera (FAC) \\
\hline Persea palustris (OBL) & & Rhynchospora corniculata (OBL) \\
\hline Rhynchospora microcarpa (OBL) & & \\
\hline Rhynchospora miliacea (OBL) & & \\
\hline Saccharum baldwinii (OBL) & & \\
\hline Woodwardia virginica (FACW) & & \\
\hline
\end{tabular}

142.32 feet above NGVD of 1929.

\begin{tabular}{|l|l} 
Acer rubrum $(\mathrm{FACW})$ & Blechnum serrulatum $(\mathrm{FACW})$ \\
Aster elliottii $(\mathrm{OBL})$ & Cyperus distinctus $(\mathrm{OBL})$ \\
Lycopus rubellus $(\mathrm{OBL})$ & Ludwigia repens $(\mathrm{OBL})$ \\
Mikania scandens $(--)$ & Lycopus rubellus $(\mathrm{OBL})$ \\
Myrica cerifera $(\mathrm{FAC})$ & Mikania scandens $(--)$ \\
Panicum hemitomon $(\mathrm{OBL})$ & Pluchea odorata $(\mathrm{FACW})$ \\
Woodwardia virginica $(\mathrm{FACW})$ & Rhynchospora corniculata $(\mathrm{OBL})$
\end{tabular}


since 1978 . The water level typically is kept at 6-12 inches above land surface near the deepest point in the wetland, and the center of the wetland is not allowed to dry out seasonally. Following the onset of augmentation, Proserpinaca pectinata (OBL) and Riccia fluitans, which were previously absent, began to flourish (Ted Rochow, SWFWMD, written commun., 2003). Growth of Riccia fluitans, a floating liverwort, was most likely due to changes in water quality (an increased concentration of calcium carbonate), and growth of Proserpinaca pectinata could have been spurred by increased water clarity in the wetland. Beginning in 1985, a buildup of unconsolidated bottom sediment (4-6 inches) was observed in the wetland (Ted Rochow, SWFWMD, written commun., 2003). This flocculent material may inhibit growth of some wetland species, including pipeworts, which have not been found in W-05 Cypress since 1985.

In May 2002, water depth was about 5 inches in deep plots and Riccia fluitans was the only plant present (table 13A). The ground was saturated in intermediate plots and the OBL species Rhynchospora corniculata was abundant. Transition plots were dry, and contained a mixture of FACW and FAC plants. By October 2003, deep plots had 14 inches of water, but Riccia fluitans was still the only nonwoody plant present. Intermediate plots had 3-7 inches of standing water during October 2002 May 2004. Understory plants that were abundant in intermediate plots included several OBL species such as Rhynchospora corniculata, R. miliacea, and Sagittaria graminea (table 13B).
Transition plots generally were saturated, but without standing water, and contained FAC or FACW species including Dichanthelium commutatum, Oplismenus hirtellus, Panicum anceps, and Panicum rigidulum (table 13B).

\section{Relation of Wetland Vegetation to Bathymetry}

Locating vegetation plots at distinctly different elevations along wetland transects was a useful design element in this study because it allowed vegetation assessment results to be directly related to wetland stage. Bathymetric data further extended the usefulness of stage and vegetation data because it allowed vegetation data to be related to inundated wetland area. For example, bathymetric data indicated that at GS Cypress when the wetland stage rose to the elevation of the intermediate plots, less than 30 percent of the wetland area was flooded (table 14), and about 70 percent of the wetland area at or above this elevation was dry. Recall that intermediate plots are located at a point along a transect line where the wetland elevation is approximately halfway between the deepest point in the wetland and the wetland perimeter. By comparison at GS Marsh, nearly 60 percent of the wetland area was inundated when water reached the intermediate plots, and about 40 percent of the wetland was dry. At the 10 wetlands in this study, the percentages of the wetland-surface areas that were flooded when stage

Table 13. Vegetation in fixed plots in W-05 Cypress.

[Shaded species make up 10 percent or more of the vegetation cover in a plot; >, greater than; --, not determined]

\begin{tabular}{|c|c|c|}
\hline \multicolumn{3}{|c|}{ Depth below land-surface elevation at palmetto fringe ${ }^{1}$} \\
\hline $\begin{array}{c}\text { Transitional plots } \\
0-0.5 \text { feet }\end{array}$ & $\begin{array}{c}\text { Intermediate plots } \\
0.5-1.0 \text { feet }\end{array}$ & $\begin{array}{c}\text { Deep plots } \\
>1.0 \text { feet }\end{array}$ \\
\hline \multicolumn{3}{|l|}{ A. May 2002} \\
\hline Callicarpa americana (upland) & Lycopus rubellus $(O B L)$ & \multirow[t]{7}{*}{ Riccia fluitans (--) } \\
\hline Dichanthelium commutatum (FAC) & Rhynchospora corniculata (OBL) & \\
\hline Erechtites hieracifolia (FAC) & & \\
\hline Melothria pendula (--) & & \\
\hline Oplismenus hirtellus (FAC) & & \\
\hline Panicum rigidulum (FACW) & & \\
\hline Smilax bona-nox (--) & & \\
\hline
\end{tabular}

B. October 2002, May 2003, October 2003, and May 2004

\begin{tabular}{l|l|l}
\hline Callicarpa americana (upland) & Lycopus rubellus $(\mathrm{OBL})$ & Riccia fluitans $(--)$ \\
Dichanthelium commutatum $(\mathrm{FAC})$ & Panicum rigidulum $(\mathrm{FACW})$ \\
Melothria pendula $(--)$ & Polygonum hydropiperoides $(\mathrm{OBL})$ & \\
Oplismenus hirtellus $(\mathrm{FAC})$ & Rhynchospora corniculata $(\mathrm{OBL})$ \\
Panicum anceps (FAC) & Rhynchospora miliacea $(\mathrm{OBL})$ \\
Panicum rigidulum $(\mathrm{FACW})$ & Sagittaria graminea $(\mathrm{OBL})$ \\
Quercus laurifolia (FACW) & Thelypteris palustris $(--)$ & \\
Smilax bona-nox $(--)$ & & \\
\hline
\end{tabular}

171.47 feet above NGVD of 1929. 
Table 14. Elevation of vegetation plots and percent of wetland area inundated at specified elevations.

[Elevation is in feet above NGVD of 1929]

\begin{tabular}{|c|c|c|c|c|c|c|c|c|c|c|}
\hline \multirow[b]{2}{*}{$\begin{array}{l}\text { Wetland } \\
\text { name }\end{array}$} & \multirow[b]{2}{*}{$\begin{array}{l}\text { Wetland } \\
\text { perimeter } \\
\text { elevation }\end{array}$} & \multicolumn{3}{|c|}{ Transitional plots } & \multicolumn{3}{|c|}{ Intermediate plots } & \multicolumn{3}{|c|}{ Deep plots } \\
\hline & & $\begin{array}{c}\text { Plot } \\
\text { elevation }\end{array}$ & $\begin{array}{l}\text { Position } \\
\text { of plots } \\
\text { below } \\
\text { wetland } \\
\text { perimeter } \\
\text { (feet) }\end{array}$ & $\begin{array}{l}\text { Percent of } \\
\text { wetland } \\
\text { area } \\
\text { inundated } \\
\text { when } \\
\text { plots } \\
\text { are } \\
\text { inundated }\end{array}$ & $\begin{array}{l}\text { Plot } \\
\text { elevation }\end{array}$ & $\begin{array}{l}\text { Position } \\
\text { of plots } \\
\text { below } \\
\text { wetland } \\
\text { perimeter } \\
\text { (feet) }\end{array}$ & $\begin{array}{l}\text { Percent of } \\
\text { wetland } \\
\text { area } \\
\text { inundated } \\
\text { when } \\
\text { plots } \\
\text { are } \\
\text { inundated }\end{array}$ & $\begin{array}{l}\text { Plot } \\
\text { elevation }\end{array}$ & $\begin{array}{l}\text { Position } \\
\text { of plots } \\
\text { below } \\
\text { wetland } \\
\text { perimeter } \\
\text { (feet) }\end{array}$ & $\begin{array}{l}\text { Percent of } \\
\text { wetland } \\
\text { area } \\
\text { inundated } \\
\text { when } \\
\text { plots } \\
\text { are } \\
\text { inundated }\end{array}$ \\
\hline Duck Pond Marsh & 70.48 & 70.18 & 0.30 & 93.1 & 68.48 & 2.00 & 59.3 & 66.65 & 3.83 & 36.4 \\
\hline Green Swamp Cypress & 98.56 & 98.32 & 0.24 & 65.3 & 97.90 & 0.66 & 29.3 & 97.09 & 1.47 & 1.0 \\
\hline Green Swamp Marsh & 93.30 & 93.06 & 0.24 & 82.8 & 92.64 & 0.66 & 57.7 & 92.53 & 0.77 & 44.5 \\
\hline $\begin{array}{l}\text { Hillsborough River } \\
\text { State Park Marsh }\end{array}$ & 46.35 & 45.80 & 0.55 & 51.1 & 45.60 & 0.75 & 40.0 & 45.13 & 1.22 & 23.5 \\
\hline S-63 Cypress & 42.32 & 42.00 & 0.32 & 78.7 & 41.50 & 0.82 & 15.6 & 41.14 & 1.18 & 0.2 \\
\hline S-68 Cypress & 43.66 & 43.43 & 0.23 & 84.9 & 42.78 & 0.88 & 51.2 & 42.23 & 1.43 & 0.4 \\
\hline W-03 Marsh & 72.44 & 72.24 & 0.20 & 93.8 & 70.69 & 1.75 & 66.5 & 69.82 & 2.62 & 17.8 \\
\hline W-05 Cypress & 71.47 & 70.87 & 0.60 & 44.8 & 70.62 & 0.85 & 12.2 & 70.04 & 1.43 & 1.6 \\
\hline W-19 Cypress & 63.23 & 62.70 & 0.53 & 72.2 & 61.82 & 1.41 & 34.2 & 60.70 & 2.53 & 0.8 \\
\hline W-29 Marsh & 69.92 & 69.30 & 0.62 & 80.3 & 68.22 & 1.70 & 48.8 & 67.12 & 2.80 & 0.1 \\
\hline
\end{tabular}

reached the elevation of the intermediate plots ranged from about 12 percent at W-05 Cypress to about 66 percent at W-03 Marsh (table 14). The volumes of water required to fill the individual wetlands to the elevation of their respective intermediate plots also varied greatly, from about 0.02 acre-ft at GS Cypress to 8.4 acre-ft at Duck Pond Marsh. Without bathymetric data, these water volumes would be difficult to predict.

The differences in wetland bathymetry have important implications with respect to both the impacts of declining water levels and the benefits of raising water levels with augmentation. Theoretically, if vegetation surveys indicate the encroachment of upland plants in intermediate plots at GS Cypress and GS Marsh, the proportional wetland areas affected by such encroachment would vary between 40 and 60 percent, depending on the shape of the wetland depression. Bathymetry data can provide context and a basis for interpretation of other elevation and vegetation data as well. For example, a cypress wetland is described as "significantly harmed" in the NTB area if the median water level over a long-term period is more than $1.8 \mathrm{ft}$ below normal pool elevation (Southwest Florida Water Management District, 2003a). Four of the five cypress wetlands mapped in this study would be dry if the water level was $1.8 \mathrm{ft}$ below normal pool elevation. The fifth and deepest cypress wetland, W-19 (maximum depth $2.7 \mathrm{ft}$ ), would be flooded to about 18 percent of its total surface area if the water level was $1.8 \mathrm{ft}$ below normal pool elevation.

Bathymetry data combined with routinely collected wetland stage data can be used to describe seasonal changes in the flooded area of impaired and natural wetlands (refer to fig. 16, W-29 Marsh and GS Marsh). One or more years of stage data can be used to describe a frequency distribution of the flooded area for a given wetland, which would indicate the amount of time different percentage areas of the wetland would be flooded during those years. The distribution of vegetation in wetlands is directly related to this inundation frequency, because wetland plants have adapted to survive and flourish under a somewhat predictable range of water depth. As a result, within a given period of time, the potential effects of human water-level alterations on wetland vegetation can be assessed by comparing and contrasting the flooded-area frequencies of an impaired wetland with that of a comparable natural wetland.

Inundated area was compared at an impaired wetland (W-29 Marsh) and a natural wetland (HRSP Marsh) during the same time period. W-29 Marsh is located on a municipal well field and for 15 years or more, its annual inundation period has been shortened by the effects of ground-water withdrawal (Reynolds, Smith and Hills, 2001). During the period July 17, 2001 - July 16, 2002, the two production wells closest to W-29 (both within 1,300 ft) yielded an annual average of 740.82 million gallons (well CC-04) and 564.92 million gallons (well CC-05), for a combined total of 1,305.74 million gallons. During July 17, 2001 - July 16, 2002, W-29 Marsh had 20 percent or less of its surface area flooded about 80 percent of the period (fig. 18A), and for most of that time, the marsh was dry throughout. Only 21-60 percent of the total surface area of the wetland was inundated for the remaining 15 percent of the year (fig. 18A). In contrast, during the same period, HRSP Marsh, a natural wetland not affected by human activities including ground-water withdrawal, had more than 40 percent of its surface area inundated for about 75 percent of the time (fig. 18B). Rainfall amounts were comparable at the two wetlands during the period from July 17, 2001 - July 16, 2002: 51.59 inches at W-29 Marsh and 52.15 inches at HRSP Marsh. Therefore, it is likely that well-field pumping was responsible for the low stages and 


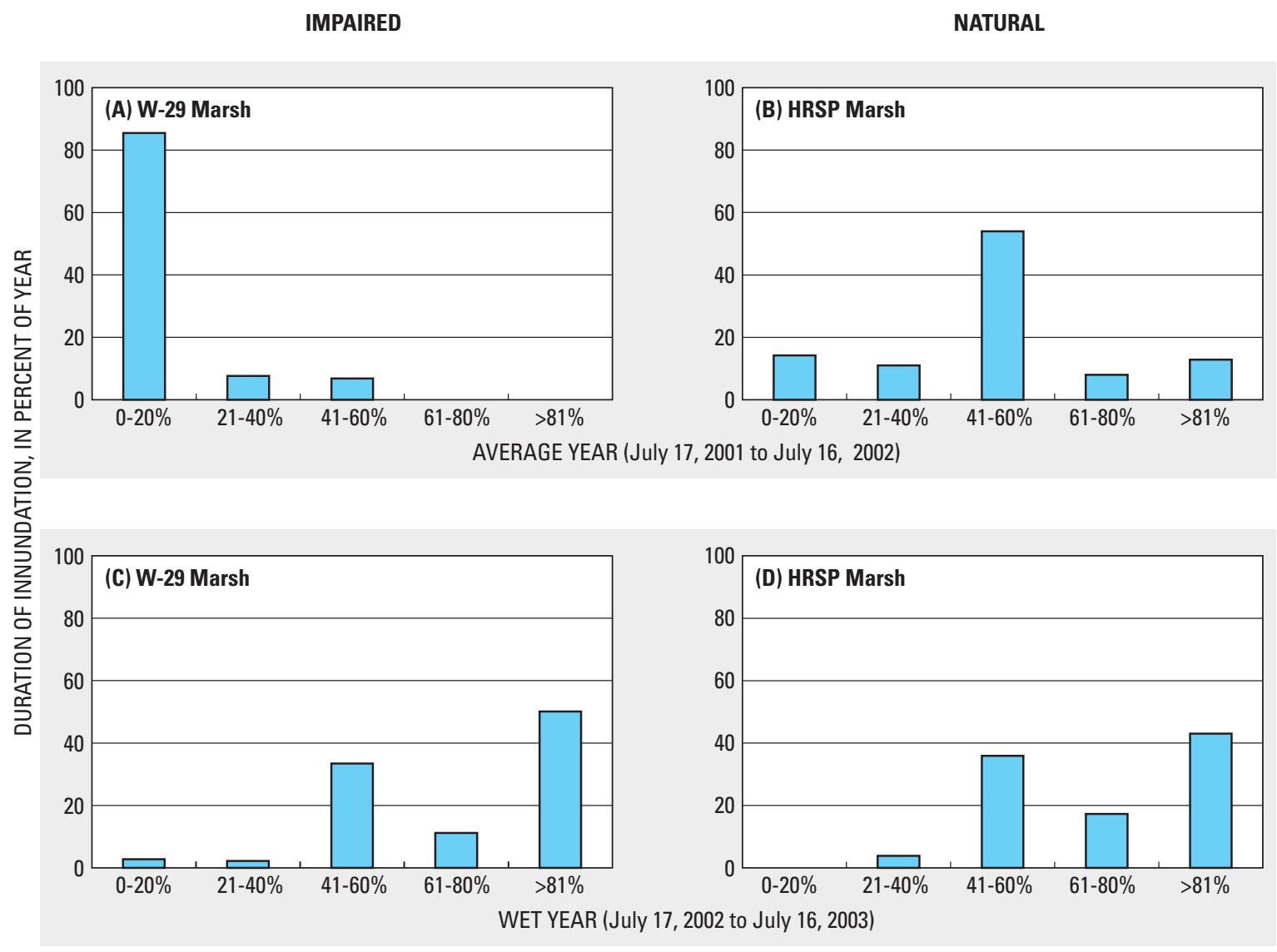

INUNDATED AREA, AS A PERCENT OF TOTAL WETLAND AREA

Figure 18. Inundated area at an impaired marsh and a natural marsh during an average year and a wet year.

small wetted areas observed at W-29 Marsh compared with HRSP Marsh during this average rainfall year (Southwest Florida Water Management District, 2003b).

In the following year (July 17, 2002 - July 16, 2003), which was wetter than the previous period, both W-29 Marsh and HRSP Marsh had more than 60 percent of their wetlandsurface areas inundated for about 60-65 percent of the year (fig. $18 \mathrm{C}, \mathrm{D})$. The similarity in flooded area between the natural wetland and the impaired wetland during this second year reflected the substantially reduced quantities of ground-water withdrawals in the vicinity of W-29 Marsh, and the increased rainfall at W-29 Marsh compared with HRSP Marsh. In fact, production at well CC-04 decreased by 40 percent and production at well CC-05 decreased by 14 percent (Tampa Bay Water, 2003).

Moreover, W-29 Marsh received almost 53 percent more rainfall and HRSP Marsh received about 25 percent more rainfall during July 2002 - July 2003 than during the previous year. As a result of the reduced pumping and increased rainfall, Upper Floridan aquifer water levels beneath W-29 Marsh averaged about $14 \mathrm{ft}$ higher during July 2002 - July 2003 than during the previous year.
Histograms were developed for W-29 Marsh and HRSP Marsh for these 2 consecutive years to show the frequency of inundation at the elevations of the transition, intermediate, and deep vegetation plots. The contrast between the natural site and the impaired site was again greatest during the average year (July 17, 2001- July 16, 2002) (fig. 19A,B). Deep plots at W-29 Marsh were inundated only 30 percent of the time (fig. 19A). A late-summer 2001 inundation may have been sufficient to support the one OBL species that grew in deep plots in May 2002. Intermediate plots were inundated less than 10 percent of the time during July 2001- July 2002, and standing water was never present in the transition plots at W-29 Marsh. The long periods of dry conditions in deep and intermediate plots at this impaired site may have prevented the growth of other OBL species and inhibited the growth of FACW species as well. Deep plots at HRSP Marsh, however, were inundated about 80 percent of the year during July 2001- July 2002 (fig. 19B). Intermediate plots were inundated for more than 70 percent of the time, and the transition plots had water at the surface more than 40 percent of the time. Long periods of inundation enhanced the survival of OBL and FACW species in deep and intermediate plots at this natural site. 


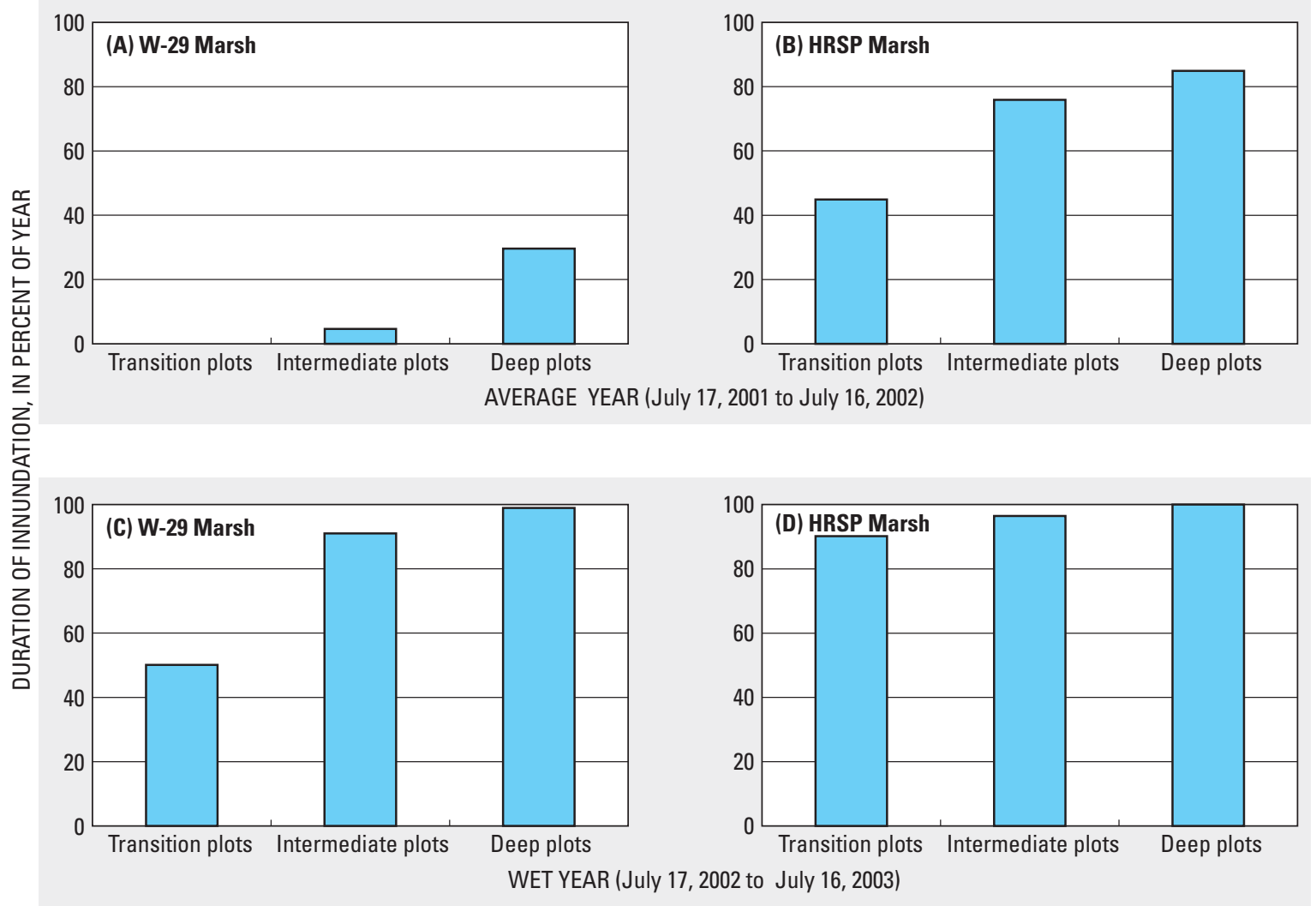

Figure 19. Duration of inundation of vegetation plots at an impaired marsh and a natural marsh during an average year and a wet year.

The following year (July 17, 2002 - July 16, 2003), the flooded area histograms for these two marshes indicate similar periods of inundation at the vegetation plots (fig. 19C,D). Intermediate and deep plots were inundated 90-100 percent of the year in both wetlands. The greatest difference occurred at the elevation of the transition plots. At W-29 Marsh, the transition plots were inundated for about 50 percent of the year (fig. 19C), whereas at HRSP Marsh transition plots had water at the surface almost 90 percent of the year (fig. 19D).

Vegetative surveys alone can be an ambiguous indicator of the frequency of flooding in different areas of some wetlands. Many herbaceous species display variable tolerances for flooding and desiccation; in this study, several species were observed across a gradient of elevation in both the impaired and natural wetlands. For example, at Green Swamp Marsh, the OBL grass Panicum hemitomon was present in deep and intermediate plots in May 2002 when the ground was saturated, with no standing water. The species was again found at this site in deep and intermediate plots in October 2003 when water depths were 10-15 inches. P. hemitomon was present (albeit at a lower density and with numerous plants apparently dead) in deep and intermediate plots at W-29 Marsh in May 2002 when those plots were dry. At W-29 Marsh in October 2003, P. hemitomon was found in all three plots where water depth ranged from 8-36 inches.
Spatial and temporal patterns of inundation sustained over a period of years determines the distribution of long-lived wetland vegetation, including trees and shrubs, and allows the longterm maintenance of viable habitat for wetland wildlife. Constructing flooded-area frequencies for natural wetlands based on long-term stage record would provide a more representative indication of long-term average conditions compared to sporadic vegetation assessments with little or no associated stage data. The utility and robustness of estimates of long-term average conditions would be enhanced if a large number of natural wetlands representing a range of hydrologic conditions could be included.

\section{Summary and Conclusions}

A careful determination of the wetland perimeter is essential for reliable stage-area and stage-volume estimates. At 9 of the 10 wetland sites in this study, the palmetto fringe was used to delineate the perimeter of the wetland and the elevation that corresponded to 100 percent inundation. The palmetto fringe was shown in separate work done by the SWFWMD to be a dependable indicator of a wetland boundary in the NTB area, both because of its low tolerance for flooding and because of the close correlation between the elevation of this plant and the 


\section{Bathymetry and Vegetation in Isolated Marsh and Cypress Wetlands in the Northern Tampa Bay Area, 2000-2004}

elevation of vegetative normal pool indicators in the interior of Florida wetlands. Hydric-soils indicators, which are considerably more labor-intensive to determine, were used to delineate the wetland perimeter at Duck Pond Marsh because no palmetto fringe or other vegetative normal pool indicators were present.

More than one approach was needed to collect bathymetric data in this study because the wetlands differ in their depth, size, extent of inundation, and density of vegetation. Choosing the appropriate density of data points needed to determine wetland bathymetry depends on the intended use of the data and the physical characteristics of the site. For example, a bathymetric map based upon fewer data points may be adequate for describing the fraction of total wetland area flooded in 20-percent intervals. In contrast wetland water budgets, which are used to estimate the volume of ground water flowing through a wetland, are very sensitive to uncertainties in stage-area and stagevolume relations, and therefore, require the greatest density of bathymetric data points possible.

For small, shallow wetlands such as those found throughout the NTB area, the most detailed bathymetric data collected were data sets collected using the Topcon method. This method requires a clear line of sight and it maps elevation data points across the entire wetland bottom at frequent and regular spatial intervals. This method was used whenever possible in this study. Simpler approaches were used when necessary to accommodate physical characteristics of the study wetlands. The collection of bathymetric data along two or three transect lines across a wetland was the simplest method tested in this study. The transect method generated values of wetland area and volume at intermediate wetland stages that were 50-100 percent lower than the approach that used a high density of data points. An alternative simple approach, which added data points along a single water-level contour to the transect data set, generated area and volume estimates that agreed much more closely with the approach using a high density of data points. In wetlands such as those in this study, the bathymetric data points along a contour line could be collected readily by using a DGPS unit to map the water's edge when the wetland is less than 100 percent inundated. Errors associated with estimates of wetland area and water volume in both of the simpler approaches were lowest when stage approached the elevation of the wetland perimeter. All three methods were subject to additional bathymetry measurement errors attributable to the vegetative cover and the rough surface of the wetland landscape.

Bathymetric data greatly extended the physical importance of stage data collected at a single point in a wetland, particularly if the point was in the deepest area of the wetland. Stage-area curves created from bathymetric data show that in all 10 wetlands, the flooded area changes markedly, and non-linearly, with wetland stage. The wetland perimeter indicates the flooded area at highest stage, but at stages below 100 percent full, bathymetric data are essential to predict flooded area. Further, it is the extent of flooded surface area, and not water level at the staff gage, that determines whether a wetland will be "wet" or "dry." When no bathymetric data are available, it is difficult to estimate flooded area from stage data. With bathymetry, stage data could be translated into spatial data on flooded area, which could then be tracked over time. Staff gages located at the lowest topographic position in a wetland were advantageous because they provided flooded-area information over the most complete range of stage and time.

Placing vegetation plots at distinct and predetermined elevations along a transect allowed wetland vegetation to be related to flooded area. A knowledge of the location and elevation of the plots can create the basis for extrapolating the composition of the vegetation community in those plots to areas of similar elevation throughout the entire wetland. Wetland bathymetry results expanded wetland vegetation community assessment into the landscape scale. The results allowed waterlevel alterations to be interpreted in terms of wetland area, and loss (or gain) of habitat. Vegetation assessments in wetlands were enhanced as a quantitative management tool when coupled with data on the elevation of vegetation plots and the location of transects and by combining vegetation results with information on wetland bathymetry.

Bathymetric data can be used to provide useful insights to water managers who may need to augment water levels of multiple impaired wetlands as well as optimize the use of a finite allocation of augmentation water. Bathymetric contours derived for the 10 wetland sites in this study indicated that at lower stages a relatively small volume of water, and sometimes a small incremental rise in stage, often increased the flooded wetland area by a large amount. When the stage approached the elevation of the palmetto fringe, a large volume of water was required to increase the surface area by a small amount. With improved information on wetland stage, area, and volume, water managers could recommend target stages in order to flood predetermined wetland-surface areas with a certain frequency.

Ideally, wetland mitigation using augmentation would attempt to approximate natural wetland flooding cycles. This would entail not only timing the presence or absence of water at the deepest point in the wetland, but also restoring the natural frequency of flooding across a range of wetland elevations. Bathymetric and long-term stage data can be used to characterize the flooded-area frequencies in natural wetlands for a given year, for different climatic cycles, and for longer historical periods. Comparing the flooded-area frequencies of natural wetlands to augmented wetlands provides a quantitative guidepost for evaluating the success of mitigation efforts in augmented wetlands from a spatial perspective. Flooded-area frequencies of impaired wetlands can be analyzed to determine the extent of hydrologic change spatially, and to select the best candidate wetlands for augmentation. Dominant plant species associated with different flooded-area frequencies in natural wetlands could provide a parallel goal for restoring vegetation in augmented wetlands, given similar bathymetry and rainfall. A drop in stage caused by human activities at an impaired wetland could be related to a decrease in flooded area, an altered vegetation community at specified elevations, and an associated 
change in wetland wildlife habitat. If these changes could be compared with contemporary natural wetlands, a semiquantitative assessment of impact could be derived even in the absence of long-term stage data or long-term monitoring.

\section{References}

Bartoldus, C.C., 1999a, A comprehensive review of wetland assessment procedures: A guide for wetland practitioners: St. Michaels, Md., Environmental Concern, Inc., 196 p.

Bartoldus, C.C., 1999b, A standard guide for the assessment of wetland functions (E1983-98): W. Conshohocken, Pa., American Society for Testing and Materials (ASTM), 27 p.

Bartoldus, C.C., 2000, The process of selecting a wetland assessment procedure: Steps and considerations: Wetland Journal, v. 12, no. 4, p. 4-40.

Berryman and Henigar, Inc., 1995, Evaluation of groundwater augmentation of wetland and aquatic habitats: Clearwater, Fla., Consultant's report prepared for West Coast Regional Water Supply Authority, 45 p.

Berryman and Henigar, Inc., 2001, J.B. Starkey wellfield and north Pasco regional wellfield ecological/hydrological monitoring program, water year 2000 annual monitoring report: Clearwater, Fla., Consultant's report prepared for Tampa Bay Water, variously paged.

Biological Research Associates, Inc., 1996, Use of lasting indicators of historic inundation patterns in isolated wetlands as reference elevations to determine areal extent and intensity of reduced water levels near areas of groundwater withdrawals: Clearwater, Fla., Consultant's report prepared for Tampa Bay Water, $10 \mathrm{p}$.

Biological Research Associates, Inc., 2001, Hydrological and ecological environmental assessment report for the Cross Bar Ranch Wellfield, Water Year 2000: Clearwater, Fla., Consultant's report prepared for Tampa Bay Water, variously paged.

Brock, M.A., Nielsen, D.L., Shiel, R.J., Green, J.D., and Langley, J.D., 2003, Drought and aquatic community resilience: The role of eggs and seeds in sediments of temporary wetlands: Freshwater Biology, v. 48, p.1207-1218.

Brooks, R.T., and Hayashi, M., 2002, Depth-area-volume and hydroperiod relationships of ephemeral (vernal) forest pools in southern New England: Wetlands, v. 22, no. 2, p. 247-255.

Buchanan, T.J., and Somers, W.P., 1982, Stage measurement at gaging stations: U.S. Geological Survey Techniques of Water-Resources Investigations, book 3, chap. A7, 28 p.

Carter, V., 1986, An overview of the hydrologic concerns related to wetlands in the United States: Canadian Journal of Botany, v. 64, p. 364-374.

Carr, D.W., and Rochow, T.F., 2004, Comparison of six biologic indicators of hydrology in isolated Taxodium ascendens domes: Brooksville, Southwest Florida Water Management District, Technical Memoranum, April 19, 2004, 4 p.
$\mathrm{CH}_{2} \mathrm{M}$ HILL, 1996, Wetlands impact, mitigation, and planninglevel cost estimating procedure: Gainesville, Fla., Technical Memorandum E.1.F, 196 p.

Darst, M.R., Light, H.M., and McPherson, B.F., 1995, Florida wetland resources, in Fretwell, J.D., Williams, J.S., and Redman, P.J. compilers, National Water Summary on Wetland Resources: U.S. Geological Survey Water-Supply Paper 2425, p. 153-160.

Dooris, P.M., Dooris, G.M., Rochow, T.F., and Lopez, M., 1990, The effects of wetland vegetation and habitat value caused by altered hydroperiods resulting from groundwater withdrawals in central Florida: Brooksville, Southwest Florida Water Management District, Environmental Section Technical Report 1990-1, 18 p.

Duever, M.J., 1988, Hydrologic processes for models of freshwater wetlands, in Mitsch, W.J., Straskraba, M., and Jorgensen, W.E., eds., Wetland Modeling, Amsterdam, Elsevier Science, p. 9-39.

Florida Department of Environmental Protection, 2004, Wetland evaluation and delineation program: Accessed June 16, 2004 at http://www.dep.state.fl.us/water/wetlands/ delineation/vegindex/vegindex.htm.

Florida Department of State, 1994, Delineation of the landward extent of wetlands and surface waters, in Florida Administrative Code, chap. 62-340, sec. 62-340.450: Vegetative index.

Gosselink, J.G., and Turner, R.E., 1978, The role of hydrology in freshwater wetland ecosystems, in Good, R.E., Whigham, D.F., and Simpson R.L., eds: Freshwater wetlands: Ecological processes and management potential: New York, Academic Press, p. 63-78.

Harris, S.W., and Marshall, W.H., 1963, Ecology of water-level manipulations on a northern marsh: Ecology, v. 44, no. 2, p. 332-343.

Hart, R., and Newman, J.R., 1995, The importance of isolated wetlands to fish and wildlife in Florida: Non-game Wildlife Program Project NG88-102: Tallahassee, Florida Game and Freshwater Fish Commission, 145 p.

Hayashi, M., and van der Kamp, G., 2000, Simple equations to represent the volume-area-depth relations of shallow wetlands in small topographic depressions: Journal of Hydrology, v. 237, p. 74-85.

Hurt, G.W., Watts, F.C., and Carlisle, V.W., 2000, Using soil morphology for the identification of seasonal high saturation, in Carlisle, V.W., and Hurt, G.W., eds., 2000, Hydric soils of Florida handbook ( $3 \mathrm{~d}$ ed.): Florida Association of Environmental Soil Scientists, p. 51-54.

Keckler, Doug, 1997, Surfer for Windows, Version 6 user's guide: Contouring and 3D surface mapping: Golden, Colo., Golden Software, Inc., variously paged.

Leibowitz, S.G., 2003, Isolated wetlands and their functions: An ecological perspective, Wetlands, v. 23, no. 3, p. 517-531.

Lewis, W.M., 2001, Wetlands explained-Wetland science, policy, and politics in America: New York, Oxford University Press, $47 \mathrm{p}$.

Lopez, Manuel, 1980, Hydrobiological monitoring of Morris Bridge well field, Hillsborough County, Florida, 1978-79 
update: Brooksville, Southwest Florida Water Management District Environmental Section Technical Report 1980-1, $68 \mathrm{p}$.

Lopez, Manuel, 1983, Hydrobiological monitoring of Morris Bridge well field, Hillsborough County, Florida, A review: 1977-1982: Brooksville, Southwest Florida Water Management District Environmental Section Technical Report 1983$5,96 \mathrm{p}$.

Mitsch, W.J., and Gosselink, J.G., 1993, Wetlands: New York, Van Nostrand Reinhold, 722 p.

Mumme, R.L., 1978, Hydrobiological monitoring of Morris Bridge well field, Hillsborough County, Florida: Southwest Florida Water Management District Environmental Section Technical Report 1978-3, 42 p.

Myers, R.L., and Ewel J.J., eds., 1990, Ecosystems of Florida: Orlando, University of Central Florida Press, 765 p.

National Research Council, 1995, Wetlands-Characteristics and boundaries: Washington, National Academy Press.

Ramsey, E.W., Nelson, G.A., Laine, S.C., Kirkman, R.G., Topham, W., 1998, Generation of coastal marsh topography with radar and ground-based measurements: Journal of Coastal Research, v. 14, no. 3, p. 1158-1164.

Reed, P.B., Jr., 1988, National list of plant species that occur in wetlands: 1988-Florida: St. Petersburg, Florida National Wetlands Inventory, U.S. Fish and Wildlife Service, 140 p.

Reynolds, Smith \& Hills, Inc., 2001, Final annual comprehensive report: Ecological and hydrological monitoring of the Cypress Creek Well Field and vicinity, Pasco County, Florida, Water Year 2000: Clearwater, Fla., Consultant's report prepared for Tampa Bay Water.

Richardson, J.L., and Vepraskas, M.J., 2001, Wetland soils: Genesis, hydrology, landscapes, and classification: Boca Raton, Fla., Lewis Publishers, 440 p.

Rochow, T.F., 1985, Hydrologic and vegetational changes resulting from underground pumping at the Cypress Creek well field, Pasco County, Florida: Florida Scientist, v. 48, no. 2, p. 65-80.

Rochow, T.F., 1994, The effects of water table level changes on freshwater marsh and cypress wetlands in the northern Tampa Bay region-A review: Brooksville, Southwest Florida Water Management District, Environmental Section Technical Report 1994-1, 21 p.

Rochow, T.F., 1998, The effects of water table level changes on freshwater marsh and cypress wetlands in the northern Tampa Bay region-A review: Brooksville, Southwest Florida Water Management District, Environmental Section Technical Report 1998-1, 64 p.

Rochow, T.F., and Lopez, M., 1984, Hydrobiological monitoring of cypress domes in the Green Swamp area of Lake and Sumter Counties, Florida, 1979-1982: Brooksville, Southwest Florida Water Management District Environmental Section Technical Report 1984-1, 79 p.

Ross, M.S., Reed, D.L., Sah, J.P., Ruiz, P.L., and Lewin, M.T., 2003, Vegetation: Environment relationships and water management in Shark Slough, Everglades National Park: Wetlands Ecology and Management, v. 11, p. 291-303.
Schalles, J.F., and Shure, D.J., 1989, Hydrology, community structure, and productivity patterns of a dystrophic Carolina bay wetland. Ecological Monographs, v. 59, p. 365-385.

Southwest Florida Water Management District, 1985, The Green Swamp Project Environmental Report: Brooksville, variously paged.

Southwest Florida Water Management District, 1999, Northern Tampa Bay Phase II Scope of Work: Brooksville, Accessed February 20, 2004 at http://www.swfwmd.state.fl.us/ waterres/ntb/files/ntbii.pdf.

Southwest Florida Water Management District, 2003a, Rules of the Southwest Florida Water Management District: Water levels and rates of flow: Brooksville, chap. 40 D-8, 52 p.

Southwest Florida Water Management District, 2003b, Rainfall data summaries: Brooksville, Accessed October 15, 2004 at http://www.swf-wmd.state.fl.us/data/wmdbweb/ rainsum.htm.

Spence, D.H.N., 1982, The zonation of plants in freshwater lakes: Advances in Ecological Research, v. 12, p. 37-125.

Squires, L., and van der Valk, A.G., 1992, Water-depth tolerances of the dominant emergent macrophytes of the Delta Marsh, Manitoba: Canadian Journal of Botany, v. 70, p. 1860-1867.

Tampa Bay Water, 2000, Environmental management plan for the Tampa Bay Water central system wellfields, March 4, 2000: Clearwater, $58 \mathrm{p}$.

Tampa Bay Water, 2003, Optimized regional operations plan annual report for water year 2003: Prepared for Southwest Florida Water Management District: Clearwater, 36 p.

U.S. Fish and Wildlife Service, 2004, National Wetlands Inventory (NWI) Metadata: Accessed June 1, 2004, at http://wetlands.fws.gov/other/metadata/nwi_meta.txt.

van der Valk, A.G., and Welling, C.H., 1988, The development of zonation in freshwater wetlands: An experimental approach, in During, H.J., Werger, M.J., and Willems, J.H., Diversity and pattern in plant communities: The Hague, Netherlands, S.P.B. Academic Publishing.

Ward, G.M., 1998, A preliminary analysis of hydrodynamic characteristics of a small lotic wetland ecosystem: Verhein International Verein, Limnologie, v. 26, p. 1373-1376.

White, W.A., 1970. The geomorphology of the Florida Peninsula: Tallahassee, Bureau of Geology Bulletin 5, 164 p.

Winter, T.C., 1988, A conceptual framework for assessing cumulative impacts on the hydrology of non-tidal wetlands: Environmental Management, v. 12, no. 5, p. 605-620.

Winter, T.C., and LaBaugh, J.W., 2003, Hydrologic considerations in defining isolated wetlands: Wetlands, v. 23, no. 3, p. 532-540.

Wise, W.R., Annable, M.D., Walser, J.A.E., Swift, R.S., Shaw, D.T., 2000, A wetland-aquifer interaction test: Journal of Hydrology, v. 227, p. 257-272.

Wunderlin, R.P., 1998, Guide to the vascular plants of Florida: Gainesville, University Press of Florida, 809 p.

Wunderlin, R.P., and Hansen, B.F., 2004, Atlas of Florida Vascular Plants: Tampa, Institute for Systematic Botany, University of South Florida, Accessed June 28, 2004 at http://www.plantatlas.usf.edu. 


\section{Appendixes 1-13}


Appendix 1. Comprehensive list of wetland staff gages and offsets to NGVD of 1929.

[SWFWMD, Southwest Florida Water Management District; $N$, north; $W$, west; latitude and longitude in degrees $\left({ }^{\circ}\right)$, minutes $\left({ }^{\prime}\right)$, and seconds (").

\begin{tabular}{|c|c|c|c|c|}
\hline \multirow{2}{*}{ Staff gage designation } & \multirow{2}{*}{$\begin{array}{l}\text { Reading at top } \\
\text { of designated } \\
\text { staff gage } \\
\text { (feet) }\end{array}$} & \multicolumn{2}{|c|}{ Staff gage location } & \multirow{2}{*}{$\begin{array}{c}\text { Staff gage } \\
\text { offset } \\
\text { (feet) }\end{array}$} \\
\hline & & Latitude & Longitude & \\
\hline Duck Pond Marsh shallow & 10.04 & $28^{\circ} 21^{\prime} 59.04^{\prime \prime} \mathrm{N}$ & $82^{\circ} 28^{\prime} 01.92^{\prime \prime} \mathrm{W}$ & 63.82 \\
\hline Duck Pond Marsh SWFWMD & 71.30 & $28^{\circ} 21^{\prime} 59.04^{\prime \prime} \mathrm{N}$ & $82^{\circ} 28^{\prime} 01.92^{\prime \prime} \mathrm{W}$ & -0.08 \\
\hline Duck Pond Marsh deep & 6.66 & $28^{\circ} 21^{\prime} 58.68^{\prime \prime} \mathrm{N}$ & $82^{\circ} 28^{\prime} 02.64^{\prime \prime} \mathrm{W}$ & 63.83 \\
\hline Green Swamp Cypress & 2.00 & $28^{\circ} 24^{\prime} 46.80^{\prime \prime} \mathrm{N}$ & $81^{\circ} 57^{\prime} 39.60^{\prime \prime} \mathrm{W}$ & 0.02 \\
\hline Green Swamp Marsh & 98.54 & $28^{\circ} 21^{\prime} 15.48^{\prime \prime} \mathrm{N}$ & $82^{\circ} 01^{\prime} 02.28^{\prime \prime} \mathrm{W}$ & -0.15 \\
\hline $\begin{array}{l}\text { Hillsborough River } \\
\text { State Park Marsh }\end{array}$ & 50.94 & $28^{\circ} 08^{\prime} 49.20^{\prime \prime} \mathrm{N}$ & $82^{\circ} 13^{\prime} 40.80^{\prime \prime} \mathrm{W}$ & 0.27 \\
\hline S-63 Cypress & 3.33 & $28^{\circ} 14^{\prime} 55.32^{\prime \prime} \mathrm{N}$ & $82^{\circ} 35^{\prime} 00.24^{\prime \prime} \mathrm{W}$ & 40.41 \\
\hline S-68 Cypress & 47.53 & $28^{\circ} 14^{\prime} 18.24^{\prime \prime} \mathrm{N}$ & $82^{\circ} 34^{\prime} 29.64^{\prime \prime} \mathrm{W}$ & -0.06 \\
\hline W-03 Marsh 1 & 3.33 & $28^{\circ} 18^{\prime} 12.60^{\prime \prime} \mathrm{N}$ & $82^{\circ} 22^{\prime} 40.08^{\prime \prime} \mathrm{W}$ & 69.33 \\
\hline W-03 Marsh SWFWMD & 74.74 & $28^{\circ} 18^{\prime} 12.60^{\prime \prime} \mathrm{N}$ & $82^{\circ} 22^{\prime} 39.72^{\prime \prime} \mathrm{W}$ & -2.02 \\
\hline W-03 Marsh 3 & 3.33 & $28^{\circ} 18^{\prime} 12.60^{\prime \prime} \mathrm{N}$ & $82^{\circ} 22^{\prime} 39.72^{\prime \prime} \mathrm{W}$ & 69.32 \\
\hline W-05 Cypress & 9.99 & $28^{\circ} 18^{\prime} 18.36^{\prime \prime} \mathrm{N}$ & $82^{\circ} 22^{\prime} 55.20^{\prime \prime} \mathrm{W}$ & 63.30 \\
\hline W-19 Cypress & 6.65 & $28^{\circ} 16^{\prime} 42.24^{\prime \prime} \mathrm{N}$ & $82^{\circ} 23^{\prime} 51.72^{\prime \prime} \mathrm{W}$ & 60.14 \\
\hline W-29 Marsh B1 & 9.99 & $28^{\circ} 17^{\prime} 58.20^{\prime \prime} \mathrm{N}$ & $82^{\circ} 23^{\prime} 16.80^{\prime \prime} \mathrm{W}$ & 64.11 \\
\hline W-29 Marsh B2 USGS & 3.34 & $28^{\circ} 17^{\prime} 53.88^{\prime \prime} \mathrm{N}$ & $82^{\circ} 23^{\prime} 12.84^{\prime \prime} \mathrm{W}$ & 67.20 \\
\hline
\end{tabular}

${ }^{1}$ Reading at top of staff gage was used to distinguish between multiple unmarked or poorly marked staff gages at a single wetland. 
Appendix 2. Estimated area and volume of water corresponding to stage and depth below land surface elevation at palmetto fringe in Duck Pond Marsh.

[Stage, elevation in feet above NGVD of 1929. Area and volume values derived using SURFER]

\begin{tabular}{|c|c|c|c|}
\hline $\begin{array}{l}\text { Depth } \\
\text { (feet) }\end{array}$ & Stage & $\begin{array}{c}\text { Area } \\
\text { (acres) }\end{array}$ & $\begin{array}{c}\text { Volume } \\
\text { (acre-feet) }\end{array}$ \\
\hline 0 & 70.48 & 5.19 & 16.61 \\
\hline 0.1 & 70.38 & 5.08 & 16.10 \\
\hline 0.2 & 70.28 & 4.97 & 15.60 \\
\hline 0.3 & 70.18 & 4.86 & 15.11 \\
\hline 0.4 & 70.08 & 4.75 & 14.63 \\
\hline 0.5 & 69.98 & 4.64 & 14.16 \\
\hline 0.6 & 69.88 & 4.54 & 13.70 \\
\hline 0.7 & 69.78 & 4.44 & 13.25 \\
\hline 0.8 & 69.68 & 4.33 & 12.81 \\
\hline 0.9 & 69.58 & 4.23 & 12.38 \\
\hline 1.0 & 69.48 & 4.13 & 11.96 \\
\hline 1.1 & 69.38 & 4.02 & 11.56 \\
\hline 1.2 & 69.28 & 3.91 & 11.16 \\
\hline 1.3 & 69.18 & 3.81 & 10.77 \\
\hline 1.4 & 69.08 & 3.70 & 10.40 \\
\hline 1.5 & 68.98 & 3.59 & 10.03 \\
\hline 1.6 & 68.88 & 3.48 & 9.68 \\
\hline 1.7 & 68.78 & 3.38 & 9.34 \\
\hline 1.8 & 68.68 & 3.28 & 9.00 \\
\hline 1.9 & 68.58 & 3.18 & 8.68 \\
\hline 2.0 & 68.48 & 3.08 & 8.37 \\
\hline 2.1 & 68.38 & 2.98 & 8.06 \\
\hline 2.2 & 68.28 & 2.90 & 7.77 \\
\hline 2.3 & 68.18 & 2.81 & 7.48 \\
\hline 2.4 & 68.08 & 2.73 & 7.21 \\
\hline 2.5 & 67.98 & 2.66 & 6.94 \\
\hline 2.6 & 67.88 & 2.59 & 6.68 \\
\hline 2.7 & 67.78 & 2.52 & 6.42 \\
\hline 2.8 & 67.68 & 2.45 & 6.17 \\
\hline 2.9 & 67.58 & 2.39 & 5.93 \\
\hline 3.0 & 67.48 & 2.31 & 5.69 \\
\hline 3.5 & 66.98 & 2.05 & 4.60 \\
\hline 4.0 & 66.48 & 1.79 & 3.64 \\
\hline 4.5 & 65.98 & 1.56 & 2.81 \\
\hline 5.0 & 65.48 & 1.37 & 2.07 \\
\hline 5.5 & 64.98 & 1.18 & 1.44 \\
\hline 6.0 & 64.48 & 0.98 & 0.90 \\
\hline 6.5 & 63.98 & 0.75 & 0.47 \\
\hline 7.0 & 63.48 & 0.43 & 0.16 \\
\hline 7.5 & 62.98 & 0.15 & 0.025 \\
\hline 8.0 & 62.48 & 0.003 & 0.000 \\
\hline
\end{tabular}

Appendix 3. Estimated area and volume of water corresponding to stage and depth below land surface elevation at palmetto fringe in Green Swamp Cypress.

[Stage, elevation in feet above NGVD of 1929. Area and volume values derived using SURFER]

\begin{tabular}{cccc}
\hline $\begin{array}{c}\text { Depth } \\
\text { (feet) }\end{array}$ & Stage & $\begin{array}{c}\text { Area } \\
\text { (acres) }\end{array}$ & $\begin{array}{c}\text { Volume } \\
\text { (acre-feet) }\end{array}$ \\
\hline 0 & 98.56 & 1.67 & 0.81 \\
0.1 & 98.46 & 1.49 & 0.65 \\
0.2 & 98.36 & 1.19 & 0.52 \\
0.3 & 98.26 & 0.94 & 0.41 \\
0.4 & 98.16 & 0.76 & 0.33 \\
0.5 & 98.06 & 0.64 & 0.26 \\
0.6 & 97.96 & 0.55 & 0.20 \\
0.7 & 97.86 & 0.45 & 0.15 \\
0.8 & 97.76 & 0.37 & 0.10 \\
0.9 & 97.66 & 0.30 & 0.071 \\
1.0 & 97.56 & 0.23 & 0.045 \\
1.1 & 97.46 & 0.16 & 0.025 \\
1.2 & 97.36 & 0.085 & 0.013 \\
1.3 & 97.26 & 0.050 & 0.007 \\
1.4 & 97.16 & 0.029 & 0.003 \\
1.5 & 97.06 & 0.012 & 0.001 \\
1.6 & 96.96 & 0.002 & 0.000 \\
\hline
\end{tabular}




\section{Bathymetry and Vegetation in Isolated Marsh and Cypress Wetlands in the Northern Tampa Bay Area, 2000-2004}

Appendix 4. Estimated area and volume of water corresponding to stage and depth below land surface elevation at palmetto fringe in Green Swamp Marsh.

[Stage, elevation in feet above NGVD of 1929. Area and volume values derived using SURFER]

\begin{tabular}{lccc}
\hline $\begin{array}{c}\text { Depth } \\
\text { (feet) }\end{array}$ & Stage & $\begin{array}{c}\text { Area } \\
\text { (acres) }\end{array}$ & $\begin{array}{c}\text { Volume } \\
\text { (acre-feet) }\end{array}$ \\
\hline 0 & 93.30 & 1.63 & 1.01 \\
0.1 & 93.20 & 1.49 & 0.85 \\
0.2 & 93.10 & 1.39 & 0.71 \\
0.3 & 93.00 & 1.29 & 0.58 \\
0.4 & 92.90 & 1.19 & 0.45 \\
0.5 & 92.80 & 1.10 & 0.34 \\
0.6 & 92.70 & 1.00 & 0.23 \\
0.7 & 92.60 & 0.90 & 0.14 \\
0.8 & 92.50 & 0.65 & 0.059 \\
0.9 & 92.40 & 0.25 & 0.012 \\
1.0 & 92.30 & 0.029 & 0.001 \\
1.1 & 92.20 & 0.000 & 0.000 \\
\hline
\end{tabular}

Appendix 5. Estimated area and volume of water corresponding to stage and depth below land surface elevation at palmetto fringe in Hillsborough River State Park Marsh.

[Stage, elevation in feet above NGVD of 1929. Area and volume values derived using SURFER]

\begin{tabular}{|c|c|c|c|}
\hline $\begin{array}{l}\text { Depth } \\
\text { (feet) }\end{array}$ & Stage & $\begin{array}{c}\text { Area } \\
\text { (acres) }\end{array}$ & $\begin{array}{c}\text { Volume } \\
\text { (acre-feet) }\end{array}$ \\
\hline 0 & 46.35 & 2.21 & 1.48 \\
\hline 0.1 & 46.25 & 1.82 & 1.28 \\
\hline 0.2 & 46.15 & 1.55 & 1.11 \\
\hline 0.3 & 46.05 & 1.41 & 0.96 \\
\hline 0.4 & 45.95 & 1.30 & 0.83 \\
\hline 0.5 & 45.85 & 1.19 & 0.70 \\
\hline 0.6 & 45.75 & 1.07 & 0.59 \\
\hline 0.7 & 45.65 & 0.93 & 0.49 \\
\hline 0.8 & 45.55 & 0.84 & 0.40 \\
\hline 0.9 & 45.45 & 0.76 & 0.32 \\
\hline 1.0 & 45.35 & 0.69 & 0.25 \\
\hline 1.1 & 45.25 & 0.62 & 0.18 \\
\hline 1.2 & 45.15 & 0.54 & 0.12 \\
\hline 1.3 & 45.05 & 0.44 & 0.075 \\
\hline 1.4 & 44.95 & 0.31 & 0.037 \\
\hline 1.5 & 44.85 & 0.13 & 0.015 \\
\hline 1.6 & 44.75 & 0.043 & 0.008 \\
\hline 1.7 & 44.65 & 0.025 & 0.004 \\
\hline 1.8 & 44.55 & 0.015 & 0.002 \\
\hline 1.9 & 44.45 & 0.009 & 0.001 \\
\hline 2.0 & 44.35 & 0.005 & 0.001 \\
\hline 2.1 & 44.25 & 0.002 & 0.000 \\
\hline
\end{tabular}


Appendix 6. Estimated area and volume of water corresponding to stage and depth below land surface elevation at palmetto fringe in S-63 Cypress.

[Stage, elevation in feet above NGVD of 1929. Area and volume values derived using SURFER]

\begin{tabular}{cccc}
\hline $\begin{array}{c}\text { Depth } \\
\text { (feet) }\end{array}$ & Stage & $\begin{array}{c}\text { Area } \\
\text { (acres) }\end{array}$ & $\begin{array}{c}\text { Volume } \\
\text { (acre-feet) }\end{array}$ \\
\hline 0 & 42.32 & 1.26 & 0.73 \\
0.1 & 42.22 & 1.19 & 0.60 \\
0.2 & 42.12 & 1.10 & 0.49 \\
0.3 & 42.02 & 1.01 & 0.38 \\
0.4 & 41.92 & 0.92 & 0.29 \\
0.5 & 41.82 & 0.83 & 0.20 \\
0.6 & 41.72 & 0.72 & 0.12 \\
0.7 & 41.62 & 0.52 & 0.057 \\
0.8 & 41.52 & 0.23 & 0.018 \\
0.9 & 41.42 & 0.066 & 0.005 \\
1.0 & 41.32 & 0.016 & 0.002 \\
1.1 & 41.22 & 0.006 & 0.001 \\
1.2 & 41.12 & 0.002 & 0.000 \\
1.3 & 41.02 & 0.000 & 0.000 \\
\hline
\end{tabular}

Appendix 7. Estimated area and volume of water corresponding to stage and depth below land surface elevation at palmetto fringe in S-68 Cypress.

[Stage, elevation in feet above NGVD of 1929. Area and volume values derived using SURFER]

\begin{tabular}{lccc}
\hline $\begin{array}{c}\text { Depth } \\
\text { (feet) }\end{array}$ & Stage & $\begin{array}{c}\text { Area } \\
\text { (acres) }\end{array}$ & $\begin{array}{c}\text { Volume } \\
\text { (acre-feet) }\end{array}$ \\
\hline 0 & 43.66 & 5.79 & 4.57 \\
0.1 & 43.56 & 5.48 & 4.00 \\
0.2 & 43.46 & 5.03 & 3.48 \\
0.3 & 43.36 & 4.65 & 3.00 \\
0.4 & 43.26 & 4.33 & 2.55 \\
0.5 & 43.16 & 4.05 & 2.13 \\
0.6 & 43.06 & 3.78 & 1.74 \\
0.7 & 42.96 & 3.51 & 1.37 \\
0.8 & 42.86 & 3.21 & 1.04 \\
0.9 & 42.76 & 2.90 & 0.73 \\
1.0 & 42.66 & 2.52 & 0.46 \\
1.1 & 42.56 & 2.04 & 0.23 \\
1.2 & 42.46 & 1.05 & 0.069 \\
1.3 & 42.36 & 0.25 & 0.012 \\
1.4 & 42.26 & 0.030 & 0.001 \\
1.5 & 42.16 & 0.000 & 0.000 \\
\hline & & & \\
\hline
\end{tabular}


Appendix 8. Estimated area and volume of water corresponding to stage and depth below land surface elevation at palmetto fringe in W-03 Marsh.

[Stage, elevation in feet above NGVD of 1929. Area and volume values derived using SURFER]

\begin{tabular}{|c|c|c|c|}
\hline $\begin{array}{l}\text { Depth } \\
\text { (feet) }\end{array}$ & Stage & $\begin{array}{c}\text { Area } \\
\text { (acres) }\end{array}$ & $\begin{array}{c}\text { Volume } \\
\text { (acre-feet) }\end{array}$ \\
\hline 0 & 72.44 & 7.38 & 13.95 \\
\hline 0.1 & 72.34 & 7.15 & 13.23 \\
\hline 0.2 & 72.24 & 6.92 & 12.52 \\
\hline 0.3 & 72.14 & 6.73 & 11.84 \\
\hline 0.4 & 72.04 & 6.56 & 11.18 \\
\hline 0.5 & 71.94 & 6.41 & 10.53 \\
\hline 0.6 & 71.84 & 6.27 & 9.90 \\
\hline 0.7 & 71.74 & 6.14 & 9.28 \\
\hline 0.8 & 71.64 & 6.02 & 8.67 \\
\hline 0.9 & 71.54 & 5.91 & 8.07 \\
\hline 1.0 & 71.44 & 5.79 & 7.49 \\
\hline 1.1 & 71.34 & 5.68 & 6.91 \\
\hline 1.2 & 71.24 & 5.57 & 6.35 \\
\hline 1.3 & 71.14 & 5.46 & 5.80 \\
\hline 1.4 & 71.04 & 5.35 & 5.26 \\
\hline 1.5 & 70.94 & 5.23 & 4.73 \\
\hline 1.6 & 70.84 & 5.11 & 4.21 \\
\hline 1.7 & 70.74 & 4.98 & 3.71 \\
\hline 1.8 & 70.64 & 4.84 & 3.22 \\
\hline 1.9 & 70.54 & 4.69 & 2.74 \\
\hline 2.0 & 70.44 & 4.53 & 2.28 \\
\hline 2.1 & 70.34 & 4.35 & 1.83 \\
\hline 2.2 & 70.24 & 4.11 & 1.41 \\
\hline 2.3 & 70.14 & 3.73 & 1.02 \\
\hline 2.4 & 70.04 & 2.92 & 0.68 \\
\hline 2.5 & 69.94 & 2.02 & 0.36 \\
\hline 2.6 & 69.84 & 1.43 & 0.26 \\
\hline 2.7 & 69.74 & 0.84 & 0.15 \\
\hline 2.8 & 69.64 & 0.21 & 0.10 \\
\hline 2.9 & 69.54 & 0.090 & 0.085 \\
\hline 3.0 & 69.44 & 0.064 & 0.078 \\
\hline 3.5 & 68.94 & 0.046 & 0.050 \\
\hline 4.0 & 68.44 & 0.035 & 0.030 \\
\hline 4.5 & 67.94 & 0.025 & 0.015 \\
\hline 5.0 & 67.44 & 0.016 & 0.005 \\
\hline
\end{tabular}

Appendix 9. Estimated area and volume of water corresponding to stage and depth below land surface elevation at palmetto fringe in W-05 Cypress.

[Stage, elevation in feet above NGVD of 1929. Area and volume values derived using SURFER]

\begin{tabular}{|c|c|c|c|}
\hline $\begin{array}{l}\text { Depth } \\
\text { (feet) }\end{array}$ & Stage & $\begin{array}{c}\text { Area } \\
\text { (acres) }\end{array}$ & $\begin{array}{c}\text { Volume } \\
\text { (acre-feet) }\end{array}$ \\
\hline 0 & 71.47 & 8.78 & 4.58 \\
\hline 0.1 & 71.37 & 8.13 & 3.74 \\
\hline 0.2 & 71.27 & 6.86 & 2.99 \\
\hline 0.3 & 71.17 & 6.05 & 2.35 \\
\hline 0.4 & 71.07 & 5.40 & 1.77 \\
\hline 0.5 & 70.97 & 4.73 & 1.27 \\
\hline 0.6 & 70.87 & 3.93 & 0.83 \\
\hline 0.7 & 70.77 & 2.49 & 0.51 \\
\hline 0.8 & 70.67 & 1.36 & 0.32 \\
\hline 0.9 & 70.57 & 0.78 & 0.21 \\
\hline 1.0 & 70.47 & 0.55 & 0.15 \\
\hline 1.1 & 70.37 & 0.39 & 0.10 \\
\hline 1.2 & 70.27 & 0.30 & 0.068 \\
\hline 1.3 & 70.17 & 0.23 & 0.041 \\
\hline 1.4 & 70.07 & 0.16 & 0.022 \\
\hline 1.5 & 69.97 & 0.093 & 0.009 \\
\hline 1.6 & 69.87 & 0.031 & 0.003 \\
\hline 1.7 & 69.77 & 0.015 & 0.001 \\
\hline 1.8 & 69.67 & 0.006 & 0.000 \\
\hline 1.9 & 69.57 & 0.000 & 0.000 \\
\hline
\end{tabular}


Appendix 10. Estimated area and volume of water corresponding to stage and depth below land surface elevation at palmetto fringe in W-19 Cypress.

[Stage, elevation in feet above NGVD of 1929. Area and volume values derived using SURFER]

\begin{tabular}{|c|c|c|c|}
\hline $\begin{array}{l}\text { Depth } \\
\text { (feet) }\end{array}$ & Stage & $\begin{array}{c}\text { Area } \\
\text { (acres) }\end{array}$ & $\begin{array}{c}\text { Volume } \\
\text { (acre-feet) }\end{array}$ \\
\hline 0 & 63.23 & 2.08 & 2.26 \\
\hline 0.1 & 63.13 & 1.96 & 2.06 \\
\hline 0.2 & 63.03 & 1.83 & 1.87 \\
\hline 0.3 & 62.93 & 1.72 & 1.69 \\
\hline 0.4 & 62.83 & 1.62 & 1.53 \\
\hline 0.5 & 62.73 & 1.53 & 1.37 \\
\hline 0.6 & 62.63 & 1.44 & 1.22 \\
\hline 0.7 & 62.53 & 1.36 & 1.08 \\
\hline 0.8 & 62.43 & 1.28 & 0.95 \\
\hline 0.9 & 62.33 & 1.19 & 0.82 \\
\hline 1.0 & 62.23 & 1.10 & 0.71 \\
\hline 1.1 & 62.13 & 1.01 & 0.60 \\
\hline 1.2 & 62.03 & 0.91 & 0.51 \\
\hline 1.3 & 61.93 & 0.82 & 0.42 \\
\hline 1.4 & 61.83 & 0.72 & 0.34 \\
\hline 1.5 & 61.73 & 0.63 & 0.28 \\
\hline 1.6 & 61.63 & 0.54 & 0.22 \\
\hline 1.7 & 61.53 & 0.47 & 0.17 \\
\hline 1.8 & 61.43 & 0.38 & 0.12 \\
\hline 1.9 & 61.33 & 0.32 & 0.089 \\
\hline 2.0 & 61.23 & 0.26 & 0.060 \\
\hline 2.1 & 61.13 & 0.19 & 0.038 \\
\hline 2.2 & 61.03 & 0.13 & 0.022 \\
\hline 2.3 & 60.93 & 0.082 & 0.011 \\
\hline 2.4 & 60.83 & 0.051 & 0.005 \\
\hline 2.5 & 60.73 & 0.022 & 0.001 \\
\hline 2.6 & 60.63 & 0.004 & 0.000 \\
\hline 2.7 & 60.53 & 0.000 & 0.000 \\
\hline
\end{tabular}

Appendix 11. Estimated area and volume of water corresponding to stage and depth below land surface elevation at palmetto fringe in W-29 Marsh.

[Stage, elevation in feet above NGVD of 1929. Area and volume values derived using SURFER]

\begin{tabular}{|c|c|c|c|}
\hline $\begin{array}{l}\text { Depth } \\
\text { (feet) }\end{array}$ & Stage & $\begin{array}{c}\text { Area } \\
\text { (acres) }\end{array}$ & $\begin{array}{c}\text { Volume } \\
\text { (acre-feet) }\end{array}$ \\
\hline 0 & 69.92 & 6.52 & 9.42 \\
\hline 0.1 & 69.82 & 6.30 & 8.78 \\
\hline 0.2 & 69.72 & 6.07 & 8.16 \\
\hline 0.3 & 69.62 & 5.85 & 7.57 \\
\hline 0.4 & 69.52 & 5.64 & 6.99 \\
\hline 0.5 & 69.42 & 5.45 & 6.44 \\
\hline 0.6 & 69.32 & 5.27 & 5.90 \\
\hline 0.7 & 69.22 & 5.09 & 5.38 \\
\hline 0.8 & 69.12 & 4.91 & 4.88 \\
\hline 0.9 & 69.02 & 4.73 & 4.40 \\
\hline 1.0 & 68.92 & 4.55 & 3.94 \\
\hline 1.1 & 68.82 & 4.37 & 3.49 \\
\hline 1.2 & 68.72 & 4.19 & 3.07 \\
\hline 1.3 & 68.62 & 4.01 & 2.66 \\
\hline 1.4 & 68.52 & 3.81 & 2.26 \\
\hline 1.5 & 68.42 & 3.60 & 1.89 \\
\hline 1.6 & 68.32 & 3.37 & 1.54 \\
\hline 1.7 & 68.22 & 3.18 & 1.22 \\
\hline 1.8 & 68.12 & 2.80 & 0.92 \\
\hline 1.9 & 68.02 & 2.41 & 0.66 \\
\hline 2.0 & 67.92 & 1.82 & 0.45 \\
\hline 2.1 & 67.82 & 1.21 & 0.30 \\
\hline 2.2 & 67.72 & 0.79 & 0.20 \\
\hline 2.3 & 67.62 & 0.59 & 0.13 \\
\hline 2.4 & 67.52 & 0.43 & 0.083 \\
\hline 2.5 & 67.42 & 0.31 & 0.046 \\
\hline 2.6 & 67.32 & 0.20 & 0.020 \\
\hline 2.7 & 67.22 & 0.10 & 0.005 \\
\hline 2.8 & 67.12 & 0.000 & 0.000 \\
\hline
\end{tabular}


Appendix 12. Names and status of wetland plants identified in fixed plots at wetland sites.

[sp., species; --, not determined; FACW, facultative wet; FAC, facultative; OBL, obligate]

\begin{tabular}{|c|c|c|}
\hline Scientific name & Common name & Status ${ }^{1,2}$ \\
\hline Acer rubrum & Red maple & FACW \\
\hline Amphicarpum muhlenbergianum & Blue maidencane & FACW \\
\hline Andropogon glomeratus var. pumilus & Bushy bluestem & -- \\
\hline Andropogon virginicus & Broomsedge bluestem & FAC \\
\hline Andropogon virginicus var. glaucus & Chalky bluestem & FAC \\
\hline Aristida condensata & Big threeawn & -- \\
\hline Aristida palustris & Longleaf threeawn & OBL \\
\hline Aristida stricta var. beyrichiana & Wiregrass & FAC \\
\hline Aster elliottii & Elliott's aster & OBL \\
\hline Berchemia scandens & Rattan vine & -- \\
\hline Blechnum serrulatum & Swamp fern & FACW \\
\hline Boehmeria cylindrica & Bog hemp & OBL \\
\hline Callicarpa americana & American beautyberry & upland \\
\hline Carex joorii & Cypress swamp sedge & FACW \\
\hline Carex longii & Long's sedge & FACW \\
\hline Carex verrucosa & Warty sedge & FACW \\
\hline Celtis laevigata & Sugarberry & FACW \\
\hline Centella asiatica & Asiatic pennywort & FACW \\
\hline Cephalanthus occidentalis & Common buttonbush & OBL \\
\hline Chara sp. & Musk-grass & -- \\
\hline Cladium jamaicense & Jamaica swamp sawgrass & OBL \\
\hline Coelorachis rugosa & Wrinkled jointtailgrass & FACW \\
\hline Conyza canadensis & Canadian horseweed & upland \\
\hline Cyperus distinctus & Swamp flatsedge & OBL \\
\hline Cyperus haspan & Haspan flatsedge & OBL \\
\hline Cyperus polystachyos & Manyspike flatsedge & FACW \\
\hline Dichanthelium commutatum & Variable witchgrass & FAC \\
\hline Dichanthelium ensifolium var. unciphyllum & Cypress witchgrass & FAC \\
\hline Dichanthelium erectifolium & Erectleaf witchgrass & OBL \\
\hline Dichanthelium sp. & Witchgrass & -- \\
\hline Eleocharis baldwinii & Baldwin's spikerush & OBL \\
\hline Eleocharis elongata & Slim spikerush & OBL \\
\hline Eleocharis equisetoides & Jointed spikerush & OBL \\
\hline Eleocharis vivipara & Viviparous spikerush & OBL \\
\hline Eragrostis spectabilis & Purple lovegrass & FAC \\
\hline Erechtites hieraciifolius & Fireweed & FAC \\
\hline Erigeron quercifolius & Oakleaf fleabane & FAC \\
\hline Eriocaulon compressum & Flattened pipewort & OBL \\
\hline Eupatorium capillifolium & Dogfennel & FAC \\
\hline Eupatorium leptophyllum & Falsefennel & OBL \\
\hline Euthamia caroliniana & Slender flattop goldenrod & FAC \\
\hline Fimbristylis autumnalis & Slender fimbry & OBL \\
\hline Fuirena squarrosa & Hairy umbrellasedge & OBL \\
\hline Galium tinctorium & Stiff marsh bedstraw & FACW \\
\hline Habeneria floribunda & Mignonette orchid & FACW \\
\hline Hydrocotyle umbellata & Manyflower marshpennywort & FACW \\
\hline Hypericum fasciculatum & Peelbark St. Johns-wort & OBL \\
\hline Hypericum myrtifolium & Myrtleleaf St. Johns-wort & FACW \\
\hline
\end{tabular}


Appendix 12. Names and status of wetland plants identified in fixed plots at wetland sites. (Continued)

[sp., species; --, not determined; FACW, facultative wet; FAC, facultative; OBL, obligate]

\begin{tabular}{|c|c|c|}
\hline Scientific name & Common name & Status ${ }^{1,2}$ \\
\hline Ilex cassine & Dahoon holly & OBL \\
\hline Ilex glabra & Gallberry & -- \\
\hline Juncus marginatus & Shore rush & FACW \\
\hline Lachnanthes caroliana & Carolina redroot & FAC \\
\hline Leersia hexandra & Southern cutgrass & OBL \\
\hline Lemna obscura & Little duckweed & OBL \\
\hline Ludwigia lanceolata & Lanceleaf primrosewillow & OBL \\
\hline Ludwigia linearis & Narrowleaf primrosewillow & OBL \\
\hline Ludwigia microcarpa & Smallfruit primrosewillow & OBL \\
\hline Ludwigia octovalis & Mexican primrosewillow & OBL \\
\hline Ludwigia repens & Creeping primrosewillow & OBL \\
\hline Lycopus rubellus & Taperleaf waterhorehound & OBL \\
\hline Lyonia lucida & Fetterbush & FACW \\
\hline Melothria pendula & Creeping cucumber & -- \\
\hline Mikania scandens & Climbing hempvine & -- \\
\hline Myrica cerifera & Wax myrtle & FAC \\
\hline Nuphar advena & Yellow pondlily & OBL \\
\hline Nymphaea odorata & American white waterlily & OBL \\
\hline Nymphoides aquatica & Big floatingheart & OBL \\
\hline Oldenlandia uniflora & Clustered mille graines & FACW \\
\hline Oplismenus hirtellus & Basketgrass & FAC \\
\hline Osmunda cinnamomea & Cinnamon fern & FACW \\
\hline Oxypolis filiformis & Water dropwort & OBL \\
\hline Paederia foetida & Skunkvine & -- \\
\hline Panicum anceps & Beaked panicum & FAC \\
\hline Panicum hemitomon & Maidencane & OBL \\
\hline Panicum rigidulum & Redtop panicum & FACW \\
\hline Panicum verrucosum & Warty panicgrass & FACW \\
\hline Panicum virgatum & Switchgrass & FACW \\
\hline Paspalum laeve & Field paspalum & FACW \\
\hline Paspalum repens & Water paspalum & OBL \\
\hline Paspalum sp. & Paspalum & -- \\
\hline Persea palustris & Swamp bay & OBL \\
\hline Phyla nodiflora & Turkey tangle fogfruit & FAC \\
\hline Pinus elliottii & Slash pine & -- \\
\hline Pluchea odorata & Sweetscent & FACW \\
\hline Pluchea rosea & Rosy camphorweed & FACW \\
\hline Polygala lutea & Orange milkwort & FACW \\
\hline Polygonum hydropiperoides & Swamp smartweed & OBL \\
\hline Pontederia cordata & Pickerelweed & OBL \\
\hline Proserpinaca palustris & Marsh mermaidweed & OBL \\
\hline Proserpinaca pectinata & Combleaf mermaidweed & OBL \\
\hline Pteridium aquilinum & Bracken fern & -- \\
\hline Ptilimnium capillaceum & Mock bishopsweed & FACW \\
\hline Quercus laurifolia & Laurel oak & FACW \\
\hline Quercus nigra & Water oak & FACW \\
\hline Quercus sp. & Oak & -- \\
\hline
\end{tabular}


Appendix 12. Names and status of wetland plants identified in fixed plots at wetland sites. (Continued) [sp., species; --, not determined; FACW, facultative wet; FAC, facultative; OBL, obligate]

\begin{tabular}{|c|c|c|}
\hline Scientific name & Common name & Status 1,2 \\
\hline Rhexia sp. & Meadowbeauty & FACW \\
\hline Rhynchospora cephalantha & Bunched beaksedge & OBL \\
\hline Rhynchospora corniculata & Shortbristle horned beaksedge & OBL \\
\hline Rhynchospora fascicularis & Fascicled beaksedge & FACW \\
\hline Rhynchospora inundata & Narrowfruit horned beaksedge & OBL \\
\hline Rhynchospora microcarpa & Southern beaksedge & OBL \\
\hline Rhynchospora miliacea & Millet beaksedge & OBL \\
\hline Riccia fluitans & Floating liverworts & -- \\
\hline Rubus cuneifolius & Sand blackberry & FAC \\
\hline Saccharum baldwinii & Narrow plumegrass & OBL \\
\hline Saccharum giganteum & Sugarcane plumegrass & OBL \\
\hline Sacciolepis striata & American cupscale & OBL \\
\hline Sagittaria graminea & Grassy arrowhead & OBL \\
\hline Sagittaria latifolia & Common arrowhead & OBL \\
\hline Salix caroliniana & Carolina willow & OBL \\
\hline Scleria baldwinii & Baldwin's nutrush & FACW \\
\hline Scleria cililata & Fringed nutrush & FACW \\
\hline Serenoa repens & Saw palmetto & -- \\
\hline Smilax bona-nox & Saw greenbrier & -- \\
\hline Smilax laurifolia & Laurel greenbrier & -- \\
\hline Taxodium ascendens & Pond-cypress & OBL \\
\hline Thelypteris palustris & Marsh fern & -- \\
\hline Toxicodendron radicans & Eastern poison ivy & -- \\
\hline Typha latifolia & Broadleaf cattail & OBL \\
\hline Ulmus americana & American elm & FACW \\
\hline Utricularia foliosa & Leafy bladderwort & OBL \\
\hline Utricularia purpurea & Eastern purple bladderwort & OBL \\
\hline Utricularia inflata & Floating bladderwort & OBL \\
\hline Vitis rotundifolia & Muscadine & -- \\
\hline Woodwardia virginica & Virginia chain fern & FACW \\
\hline Xyris fimbriata & Fringed yelloweyed grass & OBL \\
\hline
\end{tabular}

${ }^{1}$ Florida Department of Environmental Protection Wetland Evaluation and Delineation Program, accessed June 28, 2004, at http://www.dep.state.flus/water/wetlands/delineation/vegindex/vegindex/htm.

${ }^{2}$ Wunderlin, R.P., and B.F., Hansen, 2004, Atlas of Florida Vascular Plants (http://www.plantatlas.usf.edu/). [S.M., Landry and K.N., Campbell (application development), Florida Center for Community Design and Research]. Institute for Systematic Botany, University of South Florida, Tampa, accessed June 28, 2004. 
Appendix 13. Comparison of National Wetlands Inventory (NWI) and U.S. Geological Survey (USGS) wetland area estimates.

\begin{tabular}{|c|c|c|c|}
\hline Wetland & $\begin{array}{c}\text { NWI } \\
\text { area estimate } \\
\text { (acres) }\end{array}$ & $\begin{array}{c}\text { USGS } \\
\text { area estimate } \\
\text { (acres) }\end{array}$ & $\begin{array}{c}\text { Percent } \\
\text { difference } \\
\text { between NWI } \\
\text { and USGS area } \\
\text { estimates }\end{array}$ \\
\hline Duck Pond Marsh & 6.5 & 5.2 & -25 \\
\hline Green Swamp Cypress & 1.8 & 1.7 & -6 \\
\hline Green Swamp Marsh & 2.0 & 1.6 & -25 \\
\hline $\begin{array}{l}\text { Hillsborough River State } \\
\text { Park Marsh }\end{array}$ & 1.7 & 2.2 & 23 \\
\hline S-63 Cypress & 1.2 & 1.3 & 8 \\
\hline S-68 Cypress & 5.8 & 5.8 & 0 \\
\hline W-03 Marsh & 7.8 & 7.4 & -5 \\
\hline W-05 Cypress & 8.6 & 8.8 & 2 \\
\hline W-29 Marsh & 4.2 & 6.5 & 35 \\
\hline Total: & 39.6 & 40.5 & 2 \\
\hline
\end{tabular}

